Fall 1915

\title{
1915 Cedrus Yearbook
}

Cedarville College

Follow this and additional works at: https://digitalcommons.cedarville.edu/yearbooks

Part of the Higher Education Commons, Organizational Communication Commons, and the Public Relations and Advertising Commons

\section{Recommended Citation}

Cedarville College, "1915 Cedrus Yearbook" (1915). Yearbooks. 84.

https://digitalcommons.cedarville.edu/yearbooks/84

This Book is brought to you for free and open access by DigitalCommons@Cedarville, a service of the Centennial Library. It has been accepted for inclusion in Yearbooks by an authorized administrator of DigitalCommons@Cedarville. For more information, please contact digitalcommons@cedarville.edu. 


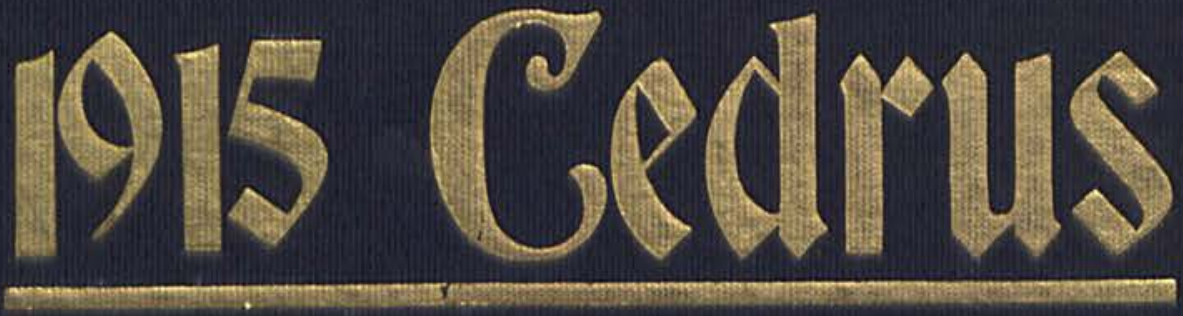




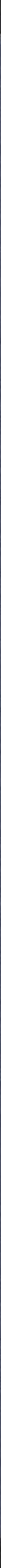




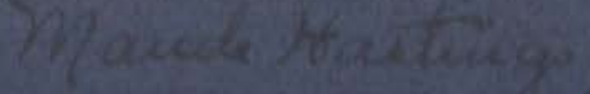




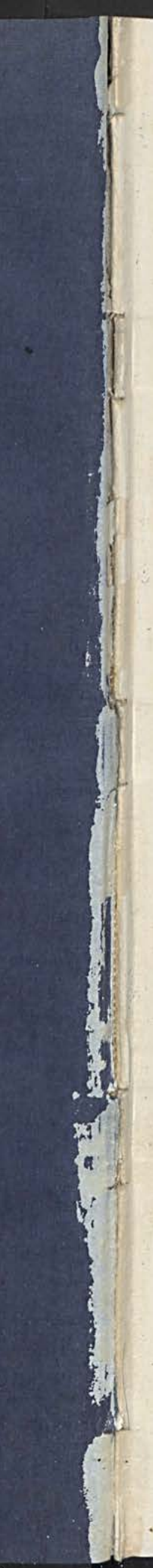




\section{CEDR US}

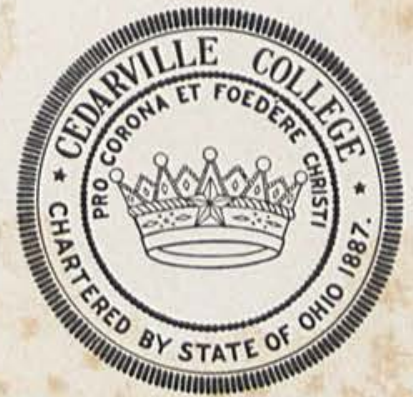

Published by the Students of

Cedarville College Cedarville, Ohio 
With Sincere Gratitude to the Teacher and

With Hearts Full of Love for the Man

We Dedicate this Book to Our Own

DR. McCHESNEY

Who for Twenty Years Has

Given of His Very Life

for

Cedarville College 

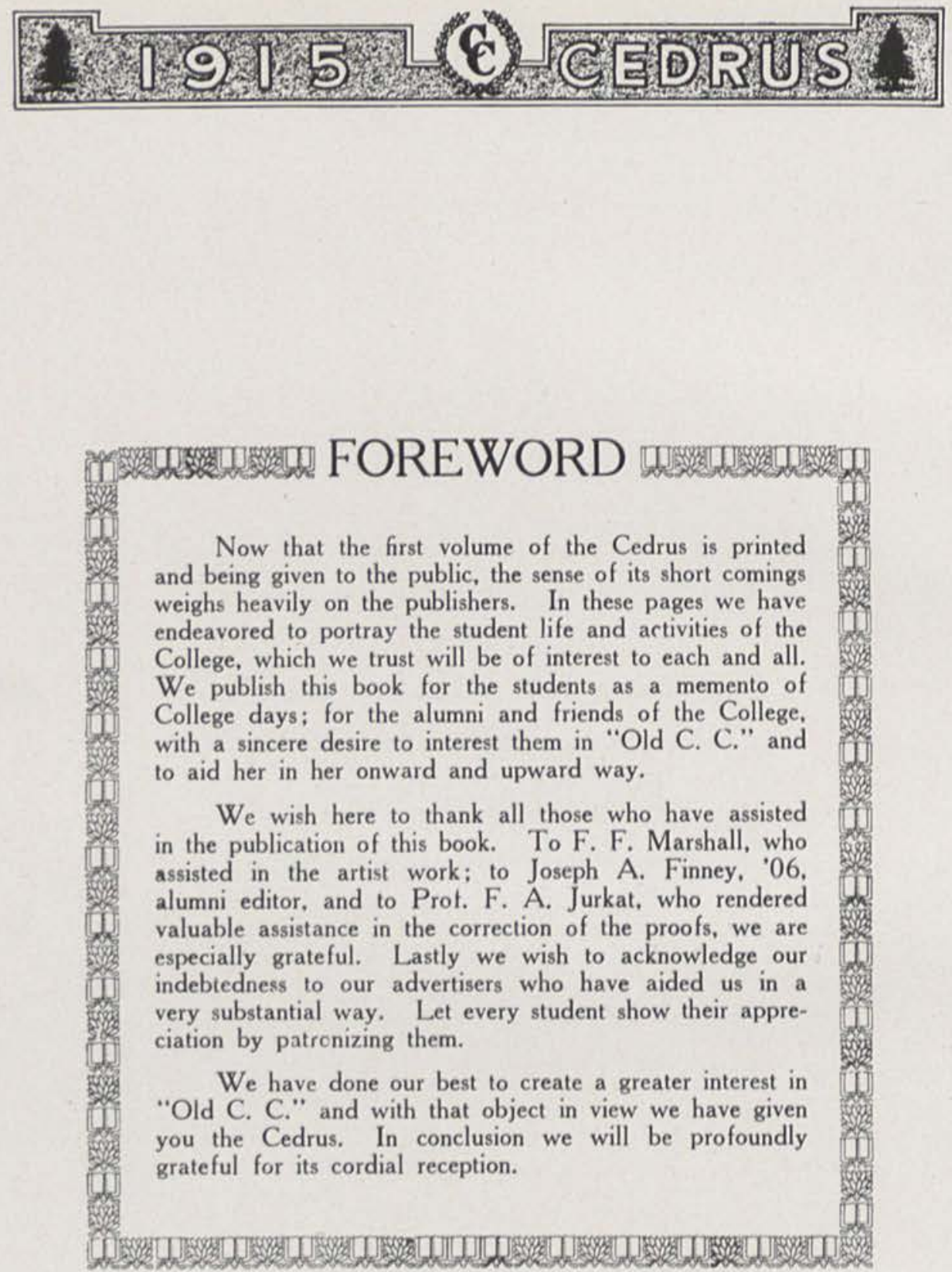

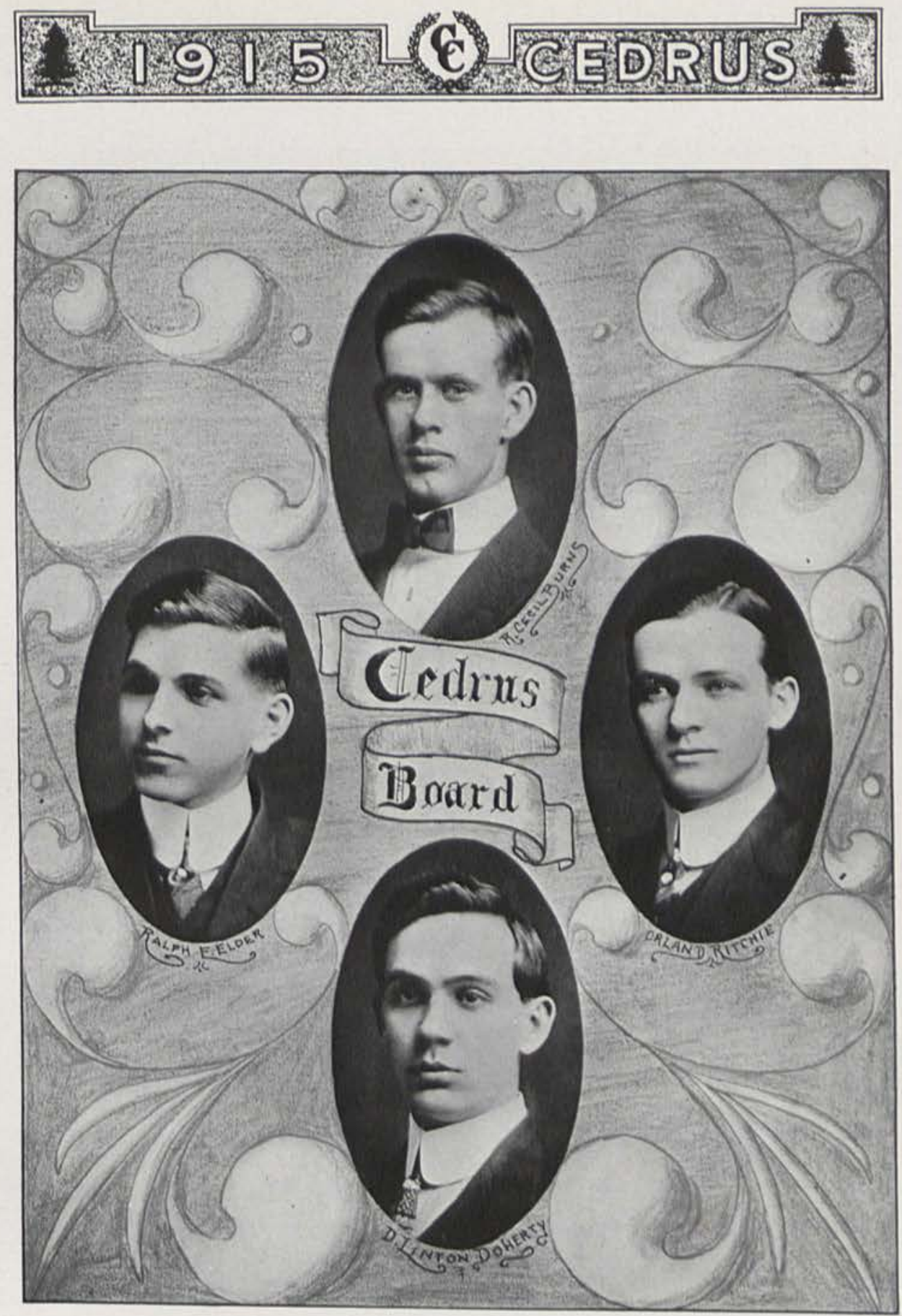

R. Cecil Burns.

Business Manager and Pictorial Editor

RALPH S. ELDER Editor-in-Chief

ORLAND M. RITCHIE. Literary Editor

D. LinTon DOHERTY Artist 

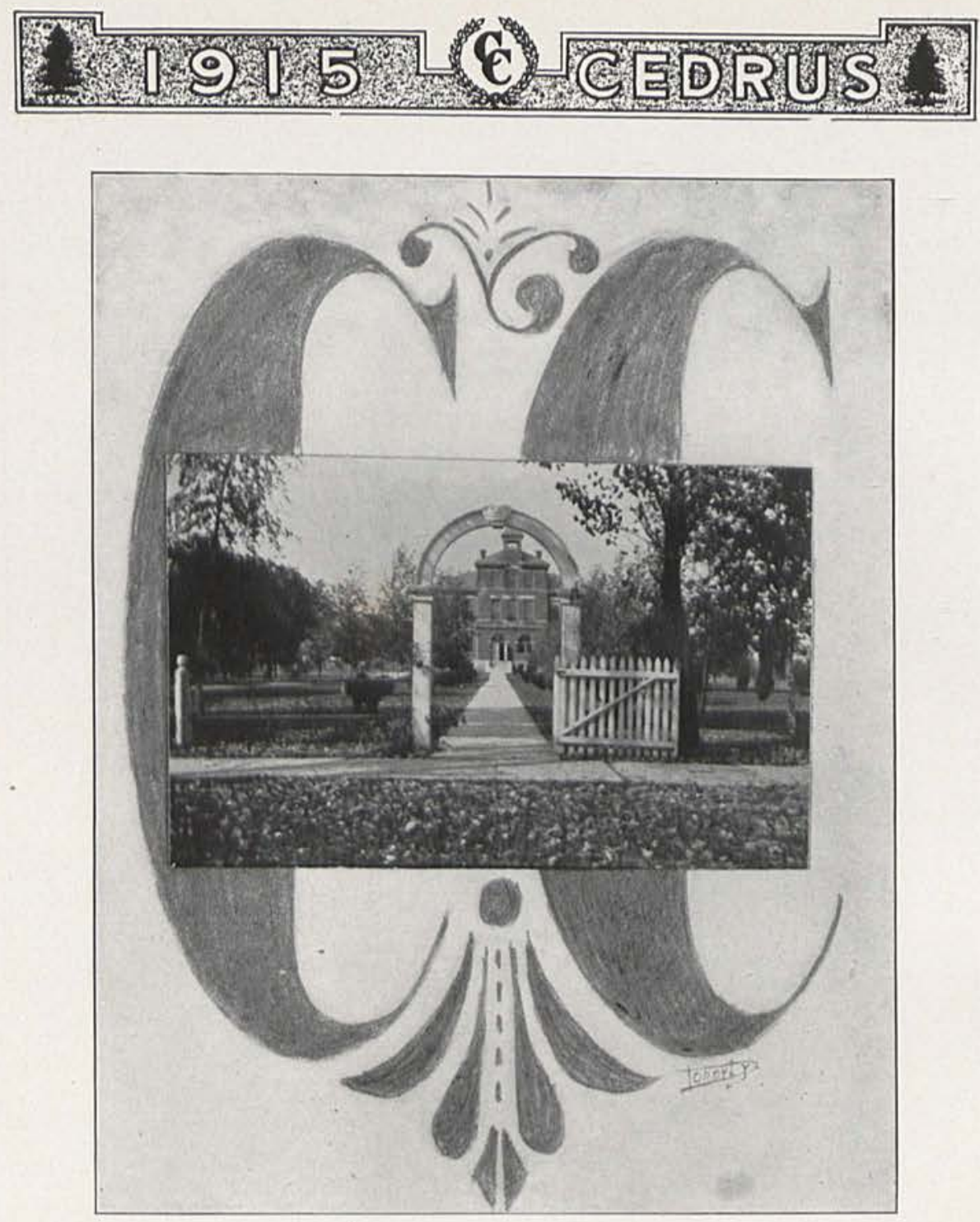

\section{Cedarville College}

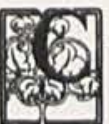

EDARVILLE COLLEGE was founded with the sublime object in view of advancing the interests of God on earth. The training of young men for the Gospel ministry, the education of young men and women for missionary service at home and abroad, and for work as laymen in the Sabbath school and in the church, were the purpose for which it was established. The development of Christian life and character in those who should go out into the world, into business and professional circles, into the arena of public life, and into the sacred precincts of the home, and carry with them some of the splendid inspiration and lofty principles imbibed at Cedarville College, was not overlooked. 


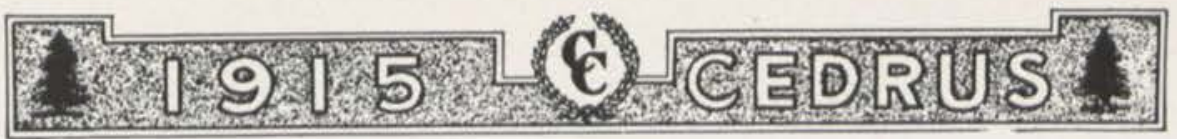

These noble ideals Cedarville has, in a remarkable degree, been able, by the blessing of Almighty God, to translate into realization. Considerably over one-third of its male graduates have become Christian ministers, and many of them are doing a great work for the Master. A goodly little band of foreign missionaries have gone out into the field as a nucleus for the many more who are yet to follow. Even more than the combined numbers of these two classes, are those in the ranks of teachers, whose influence for good in the lives of the rising generation is boundless. And to be counted only by the hundreds are those who have gone out, either as graduates, or with only partial courses to their credit, and have enriched with consecrated lives, the communities and congregations, as well as the business, professional, and social groups to which they belong, and whose characters bear testimony to the loyalty of Cedarville College to her King.

In fact the College itself has been directly engaged in doing a missionary work of no mean significance. In many cases young men and young women can point to their sojourn within the walls of old Cedarville as a period of real regeneration, when a new word with its opportunities and possibilities burst upon them, and there dawned within their minds the significance and value of their own lives to satisfy the world's need. Nay more, whole families have been lifted to a higher plane of existence and usefulness through the leavening influence of a boy or a girl sent to Cedarville College.

As a distinctively Christian College, Cedarville rejects materialistic views of life and is boldly idealistic. It emphasizes the necessity for vision, service, character. Students are taught to see the invisible, the higher spiritual realities that are concealed from eyes waxed dull and gross from viewing worldly vanities. To see the King in all His beauty, to see themselves as His children, to see the world in its need, is the first duty of the true Cedarville student.

Then comes the service to meet that need. Not to be ministered unto, but to minister, and to give their lives to the good of their fellowmen, is the aim set before the youthful and ambitious hearts. Not many Cedarville graduates will be millionaires, but many, many will lay up treasures above.

That the students may be trained for efficient service, to be workmen not needing to be ashamed, opportunity is afforded them for acquiring knowledge, for developing and increasing their powers of body, mind, and spirit, and for becoming skillful in the application of knowledge and power.

But character is the supreme aim of the College: not merely good moral character, but that which hath foundations, whose builder and maker is God; character patterned after our great Example. Jesus Christ. This paramount principle permeates every department, from those of Bible, apologetics, missions, ethics, and philosophy, to those of language, history, mathematics, and natural science. The development of proper views, right feelings, and correct habits, supersedes any striving after merely mechanical excellence. Yet the work is done in such a practical and common-sense way that even this finds its place, and contributes materially to the accomplishment of the predominant purpose. 


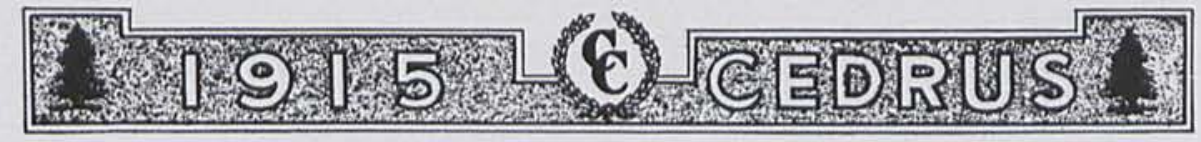

\section{Board of Trustees}

J. H. Creswell, President

Cedarville, Ohio

J. H. Stormont, First Vice President. Cedarville,Ohio

Rev. Homer McMillan, D.D., Second Vice President. Atlanta, Ga.

Oscar E. Bradfute, Secretary Cedarville, Ohio

Prof. Frank A. Jurkat, M.A., Treasurer Cedarville, Ohio A. Y. REID. Cincinnati, Ohio

Rev. David McKinNeY, D.D., LL.D. Cincinnati, Ohio Rev. William R. Graham, A.B. Yellow Springs, Ohio Joseph A. FinNey, A.B. Xenia, Ohio NATHAN L. RAMSEY Cedarville, Ohio

Prof. W. Renwick McChesney, Ph.D. Cedarville, Ohio S. C. WRIGHT, A.B. Cedarville, Ohio

\section{STANDING COMMITTEES}

Executive: Creswell, Wright, Finney, McKinney, Bradfute

Finance: Bradfute, Creswell, Reid, Stormont

Instruction: McKinney, Graham, McChesney, McMillan

Property: Stormont, Creswell, Ramsey, McKinney

Auditing: Finney, Graham, McMillan, Stormont

InVEstments: Jurkat, McKinney, Creswell

\section{LOCAL ADVISORY BOARD}

D. S. Ervin, J. C. Stormont, Thompson Crawford, G. E. Jobe, Oscar Smith

\section{WOMEN'S ADVISORY BOARD}

Mrs. W. R. McChesney, Miss Mary Ervin, Mrs. S. T. Baker, Mrs. John W. Johnson, Mrs. W. H. Barber, Mrs. Anderson Collins, Mrs. E. C. Oglesbee, Mrs. J. W. Dixon 

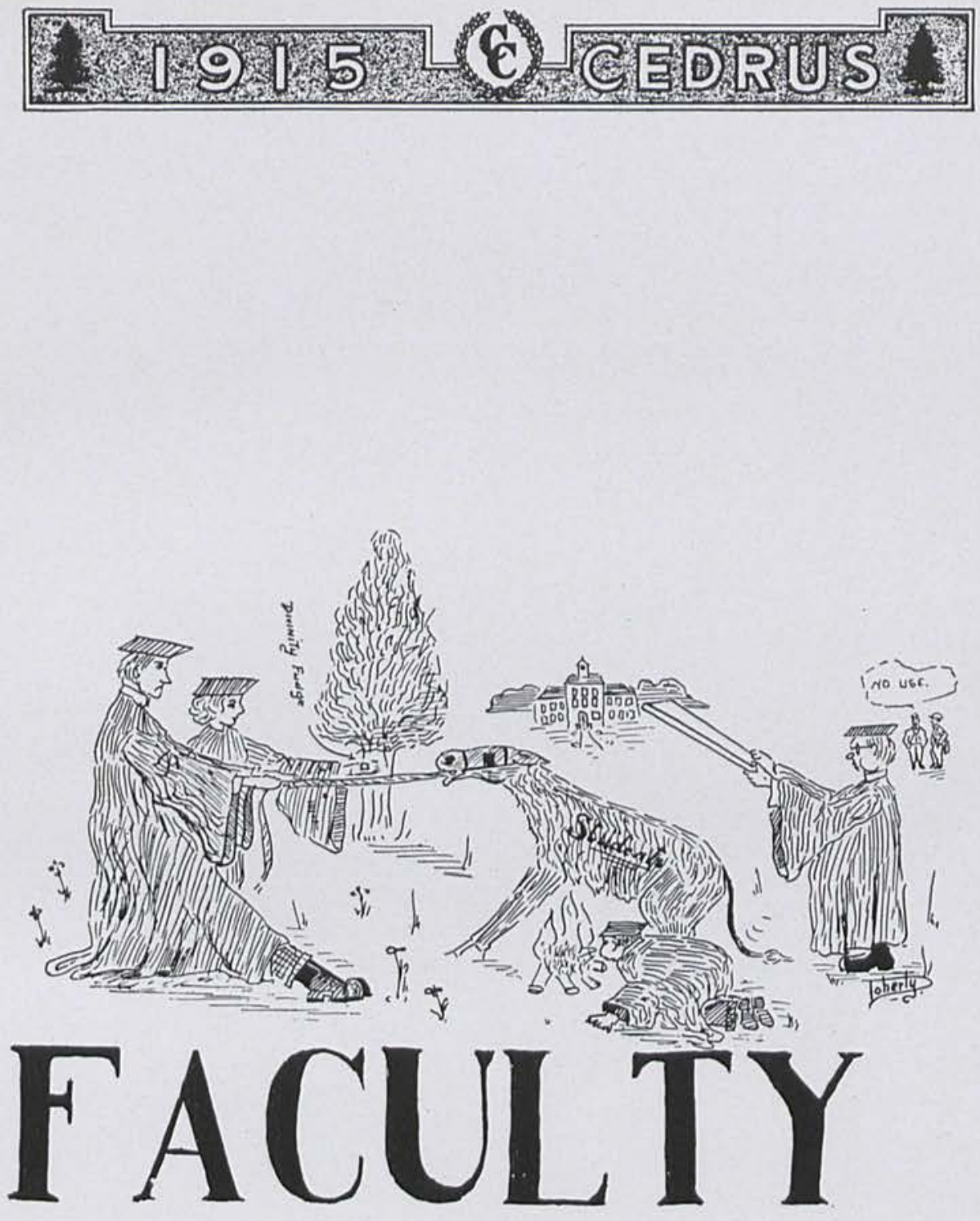

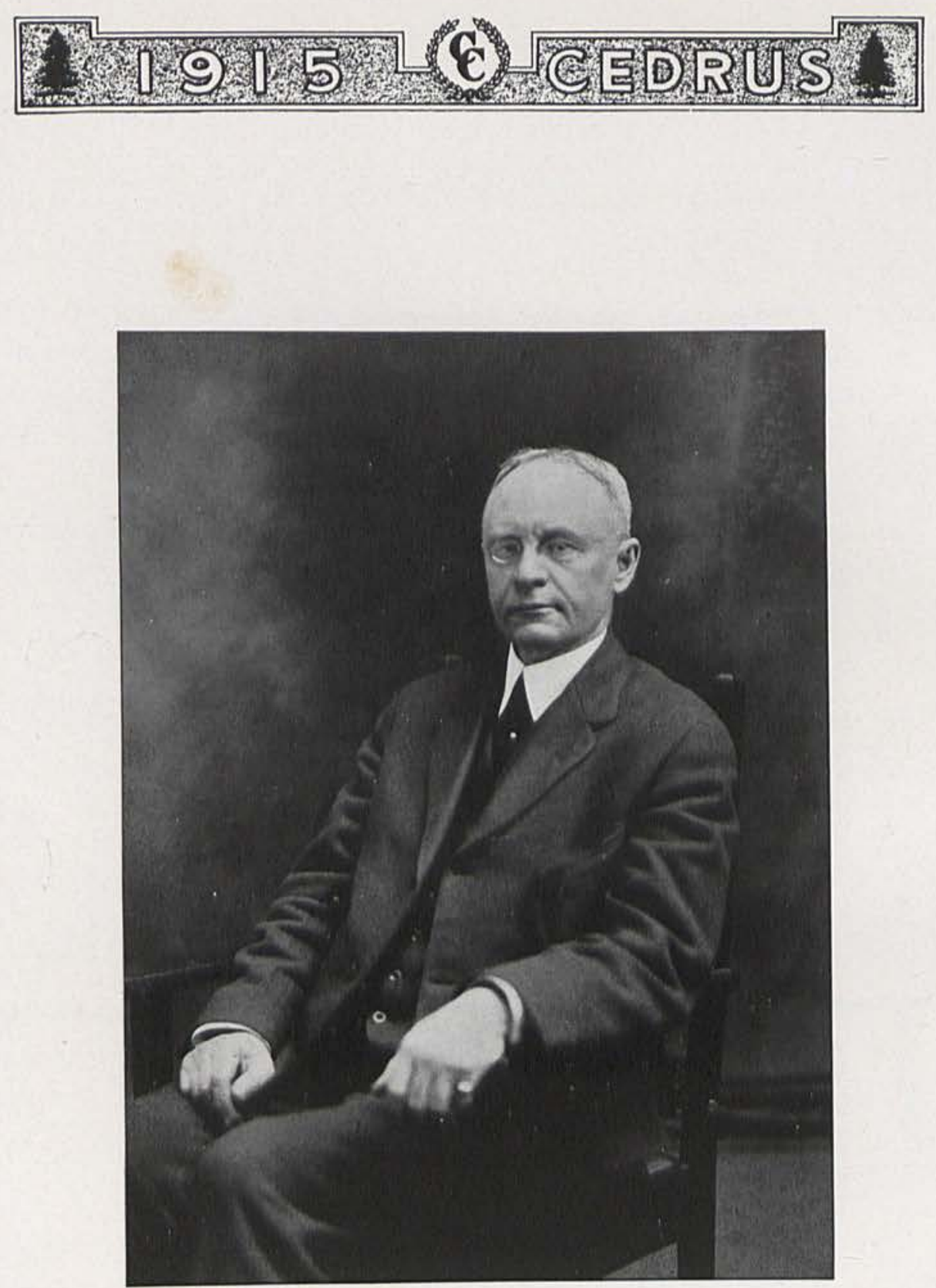

Rev. David McKinney, D.D., LL.D., President 

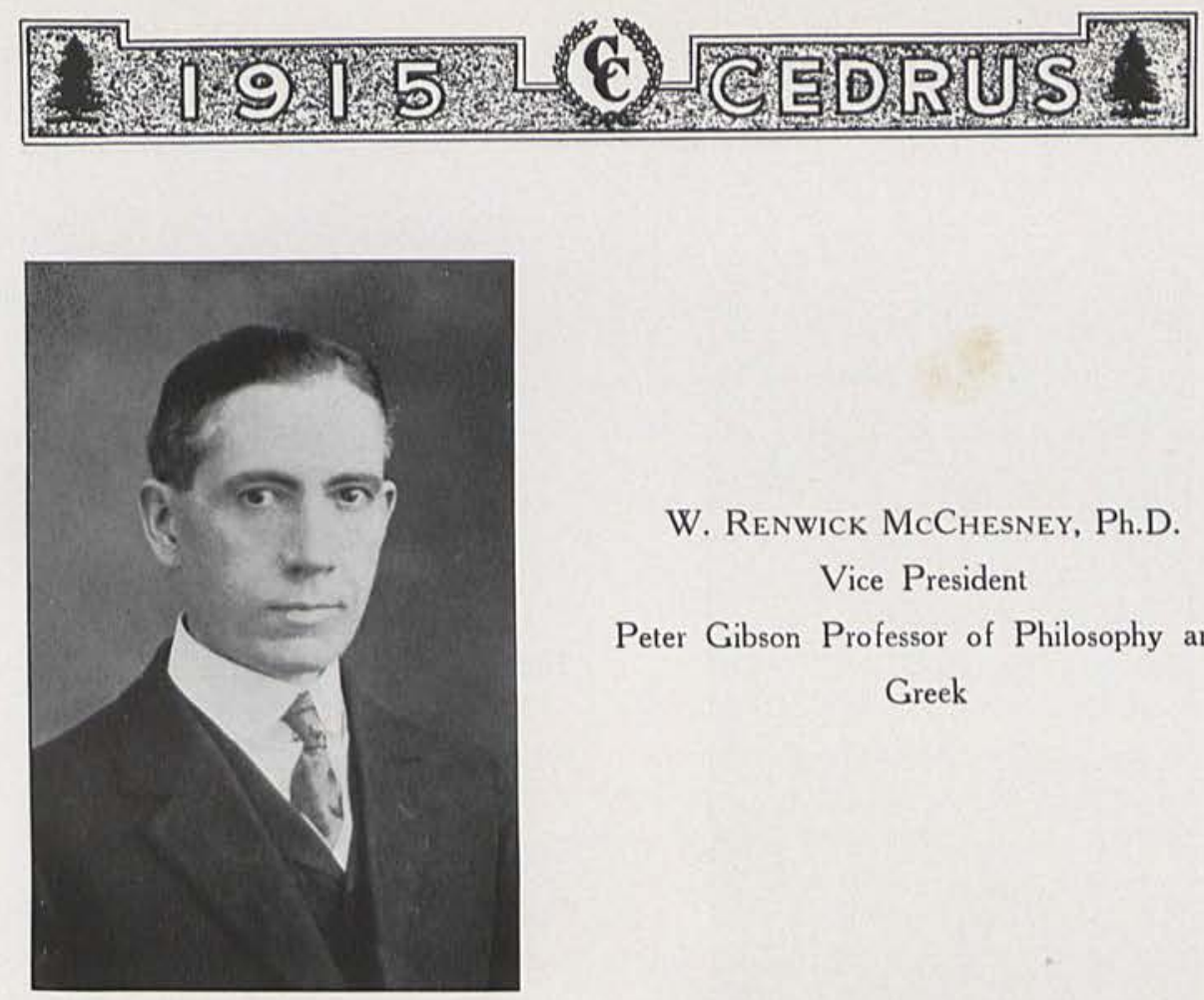

W. RENWICK McChesney, Ph.D.

Vice President

Peter Gibson Professor of Philosophy and Greek

Leroy Allen, Ph.B.

Secretary

Harper Professor of Economics and

Sociology

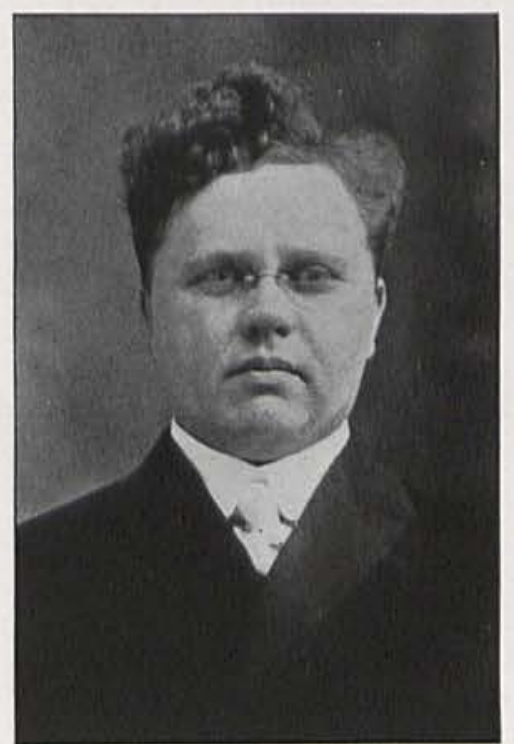



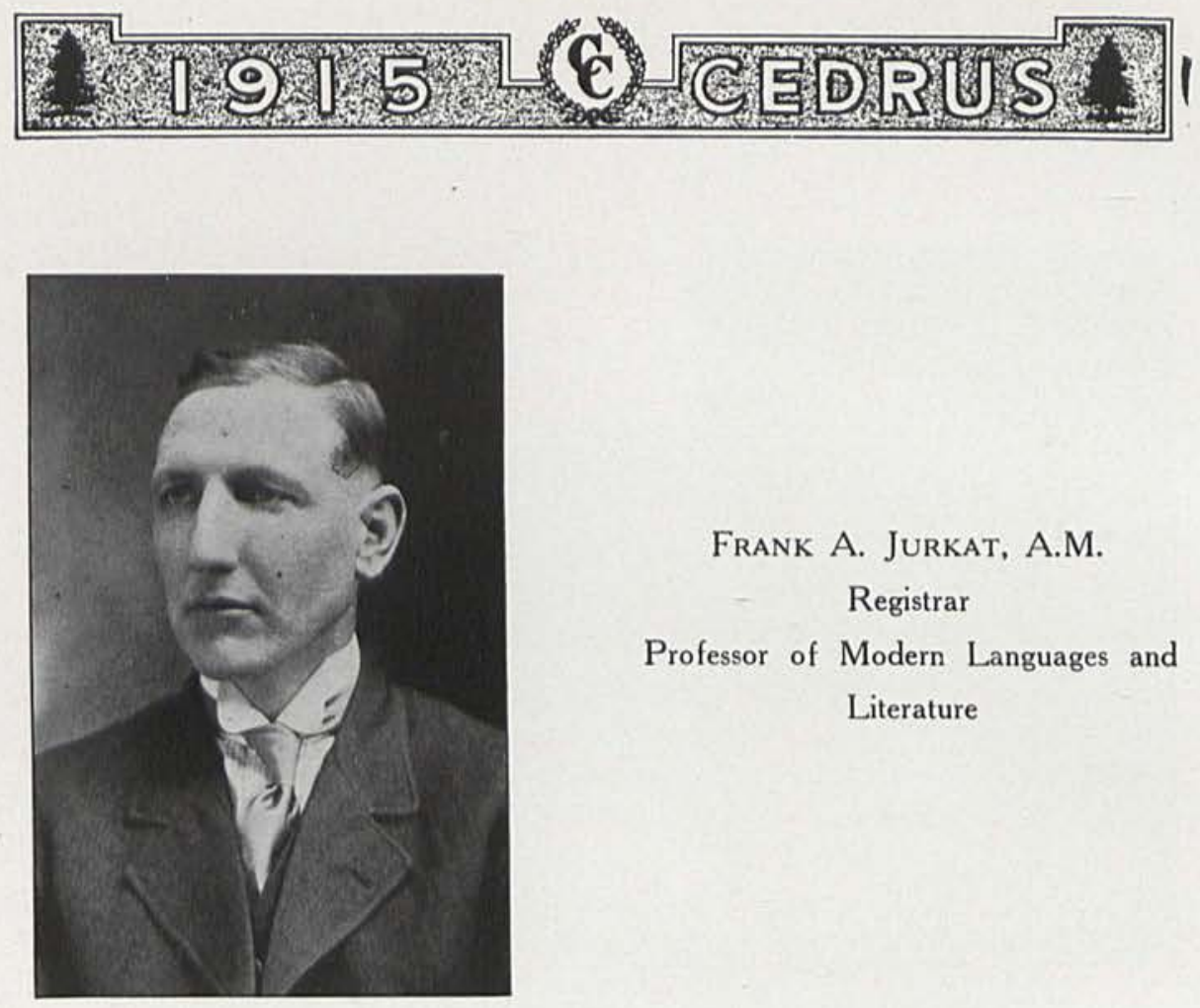

Frank A. Jurkat, A.M.

Registrar

Professor of Modern Languages and Literature

Anna Alberta Creswell, A.M.

Professor of English and French

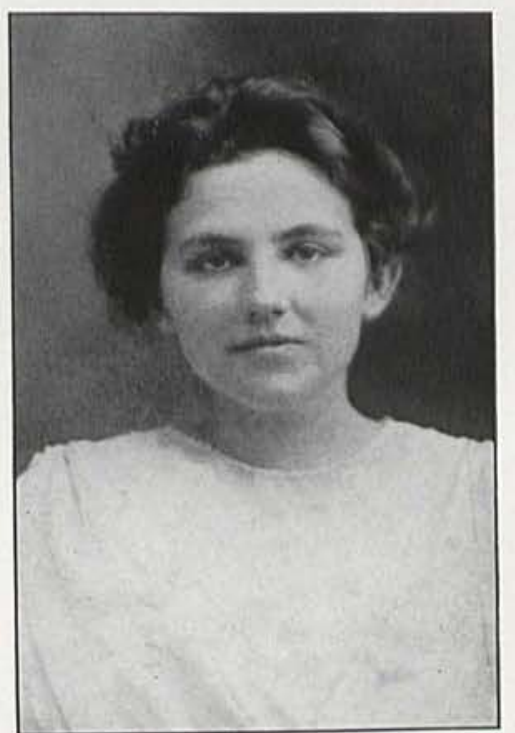



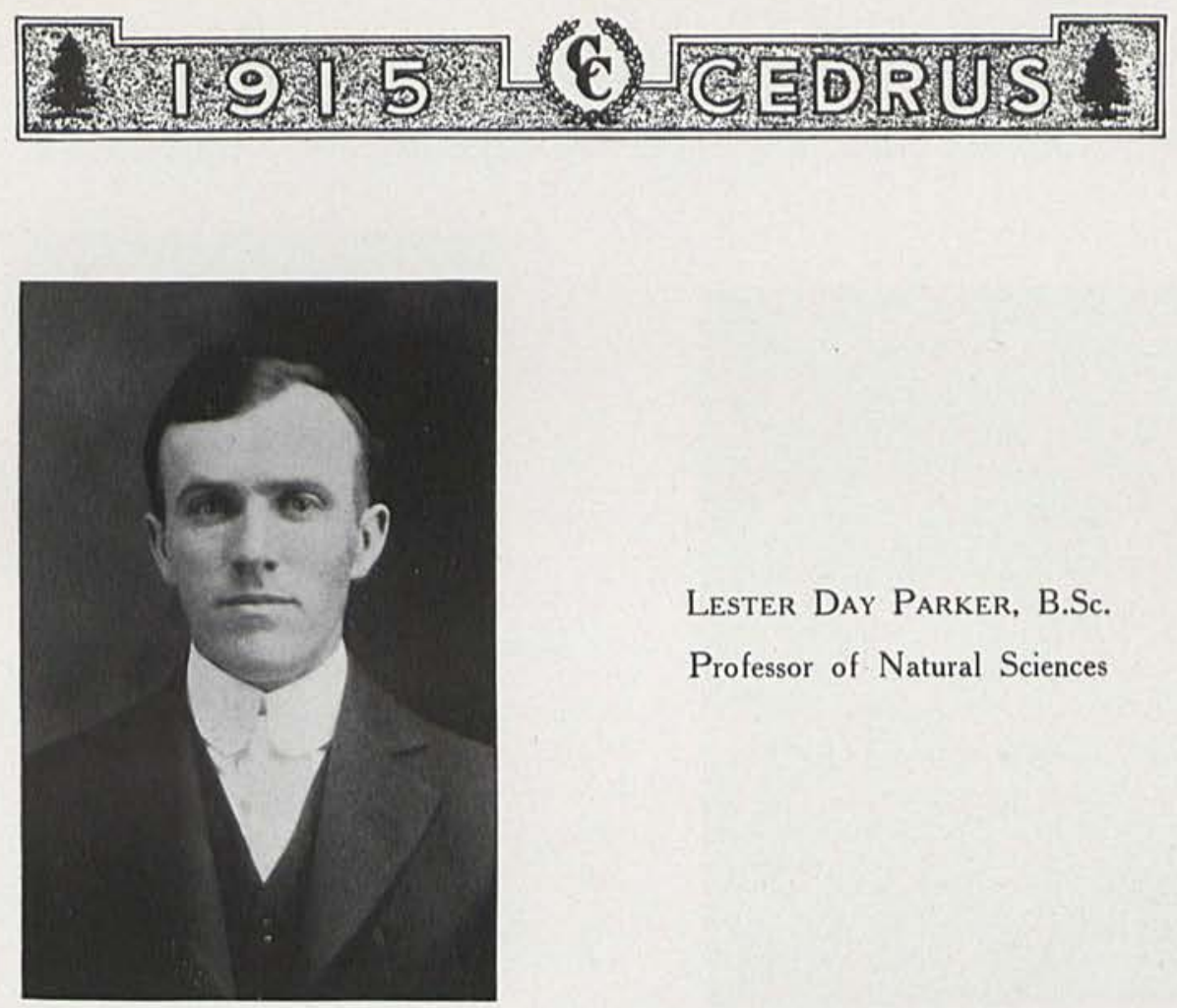

Lester Day Parker, B.Sc.

Professor of Natural Sciences

Eleanore Katherine Holliday, A.M.

Professor of German and English

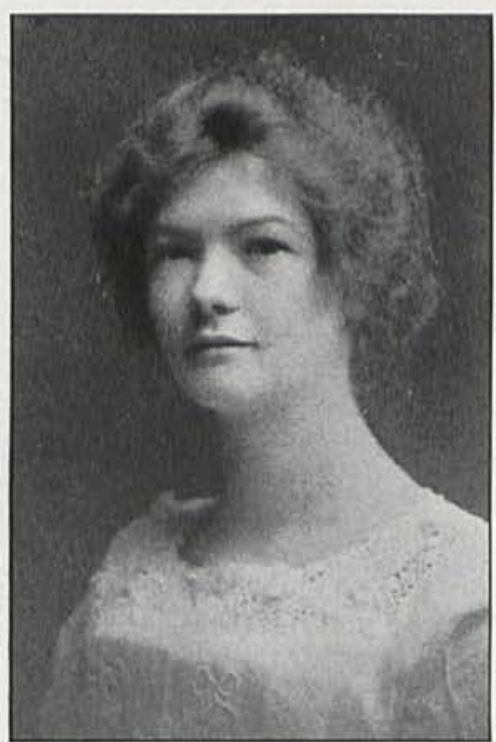



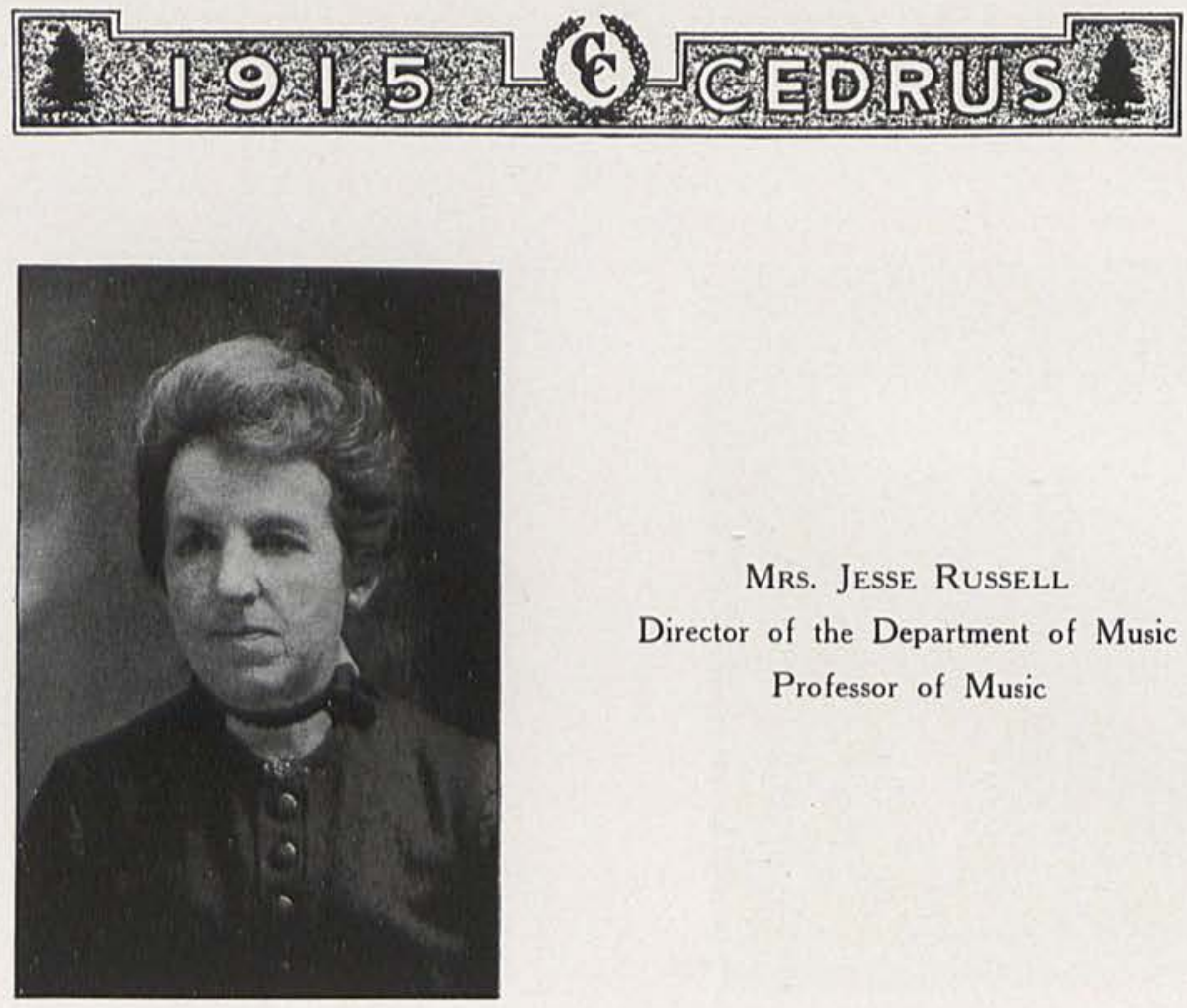

Mrs. Jesse Russell

Director of the Department of Music

Professor of Music

Stephen Calvin Wright, A.B.

Professor in the Normal Department

Financial Agent of the College

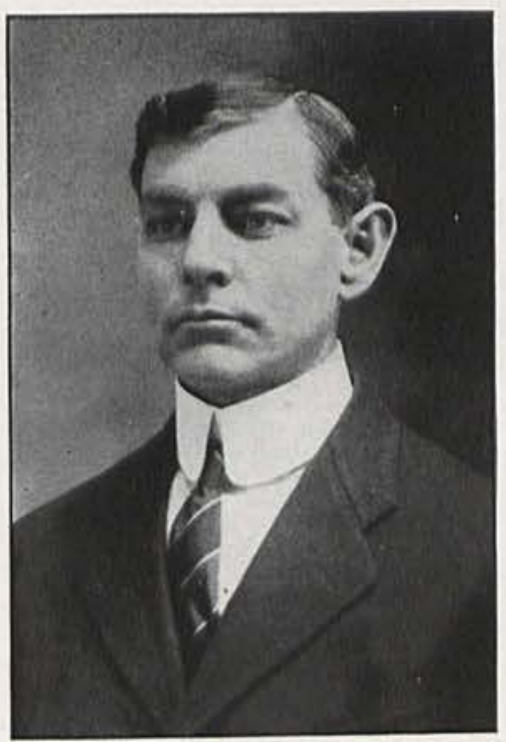



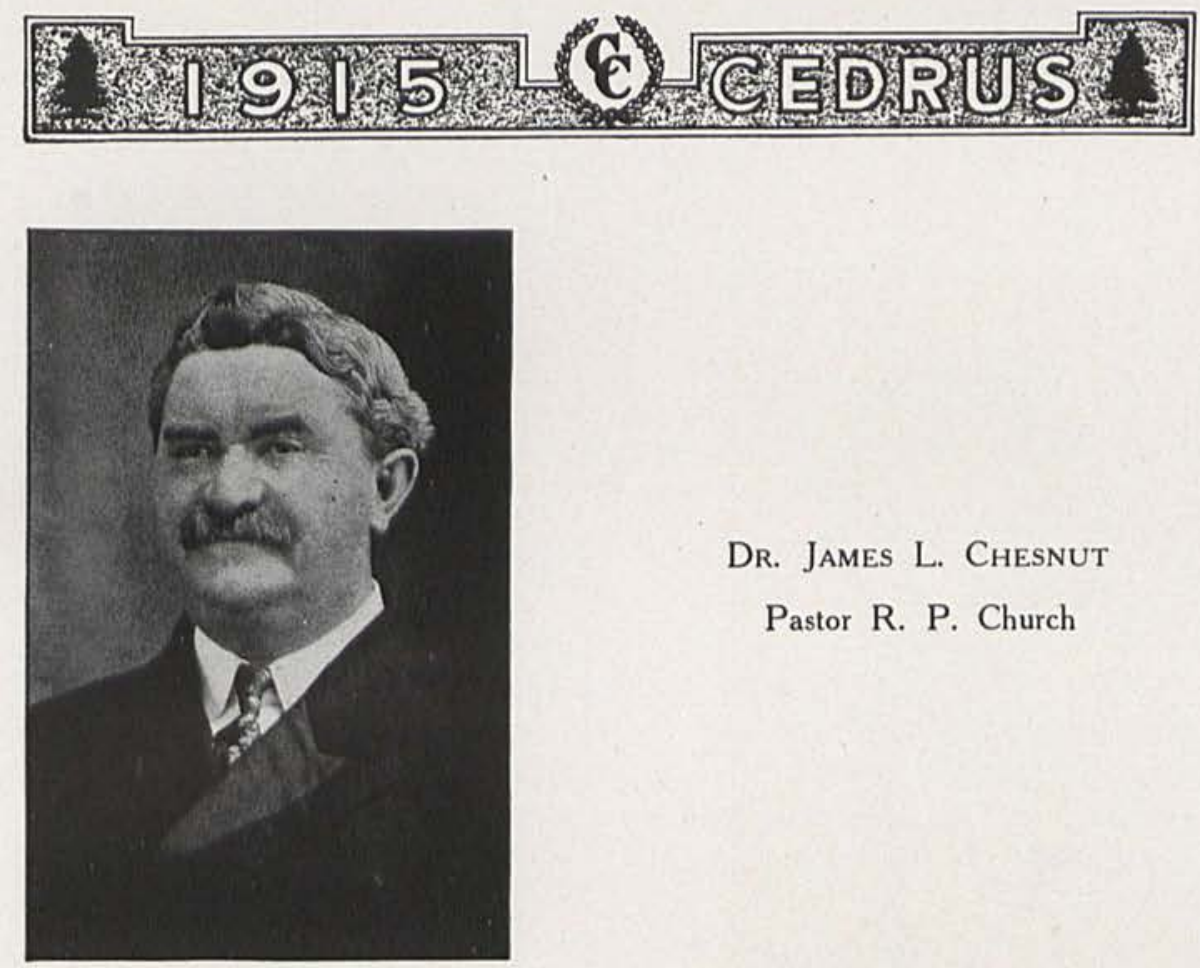

Dr. James L. Chesnut

Pastor R. P. Church

R. Cecil Burns

Instructor in Mathematics

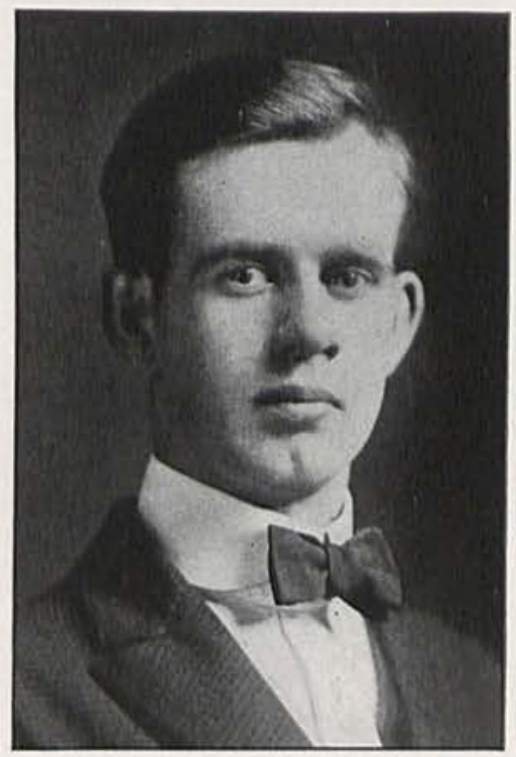



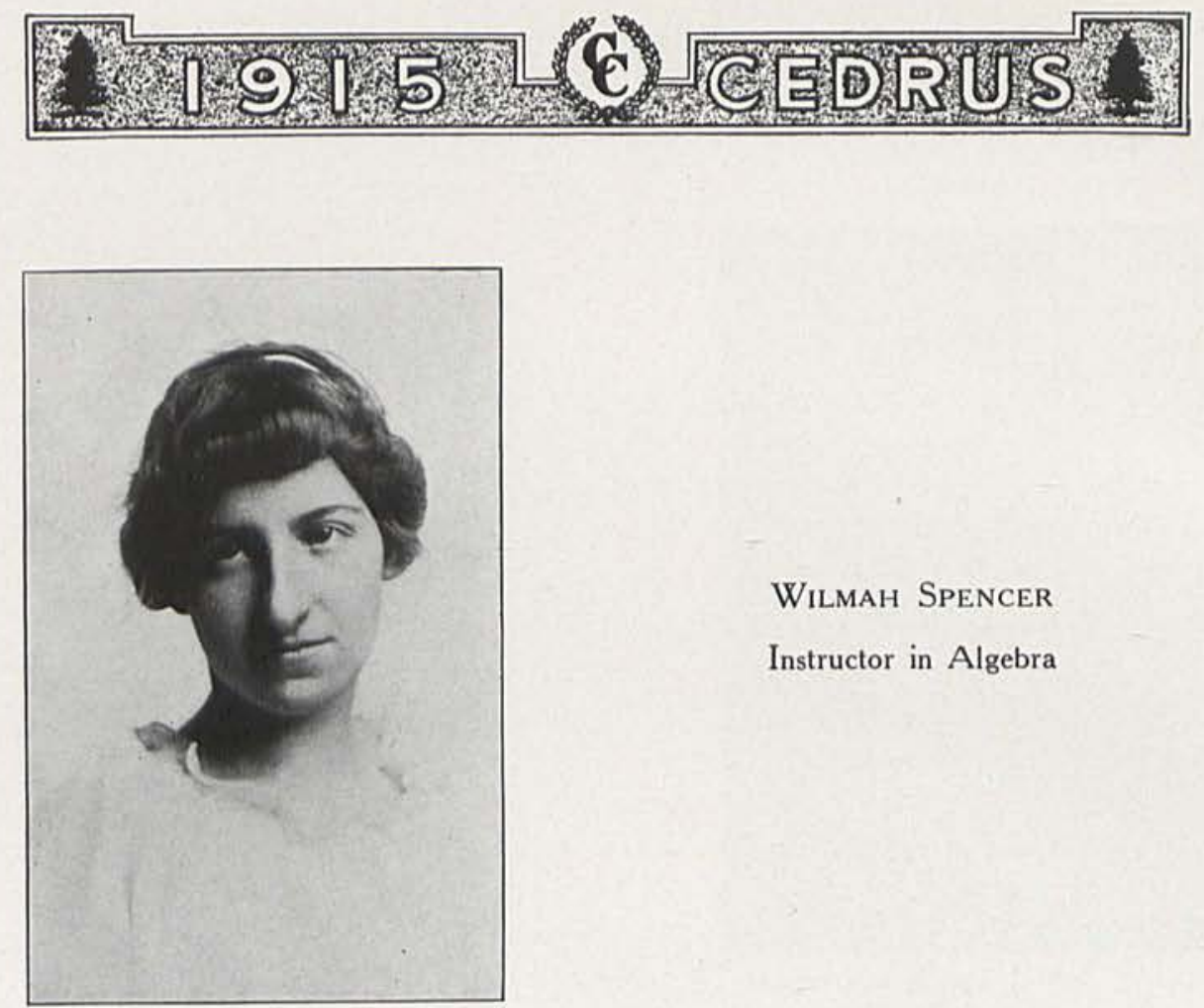

Wilmah SPencer

Instructor in Algebra

David Bradfute

Instructor in Science

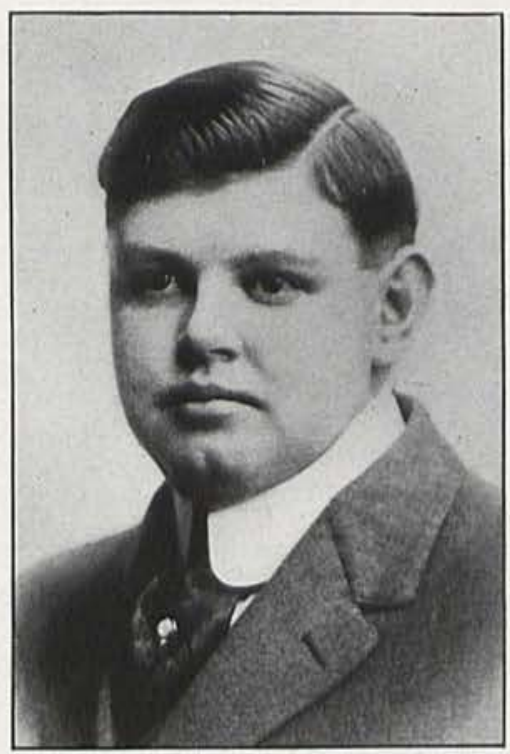




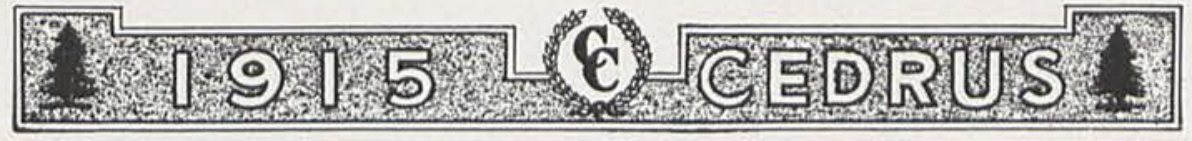

Mary B. Ervin, A.B.

Associate Professor of Philosophy and Greek

Mary Lucile Gray

Librarian

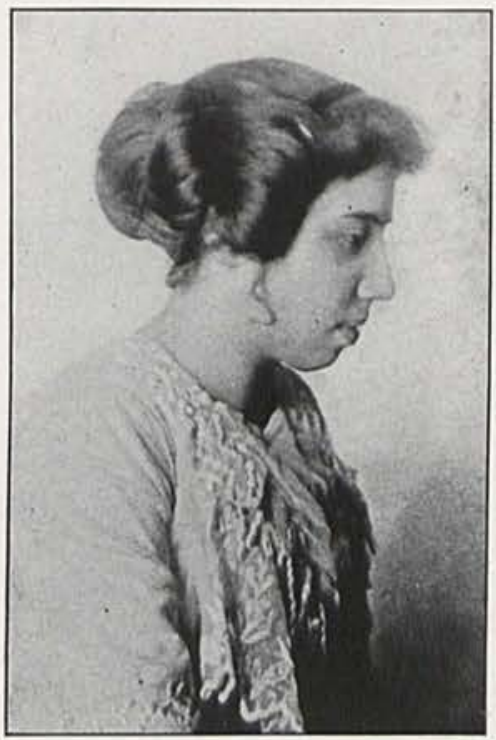



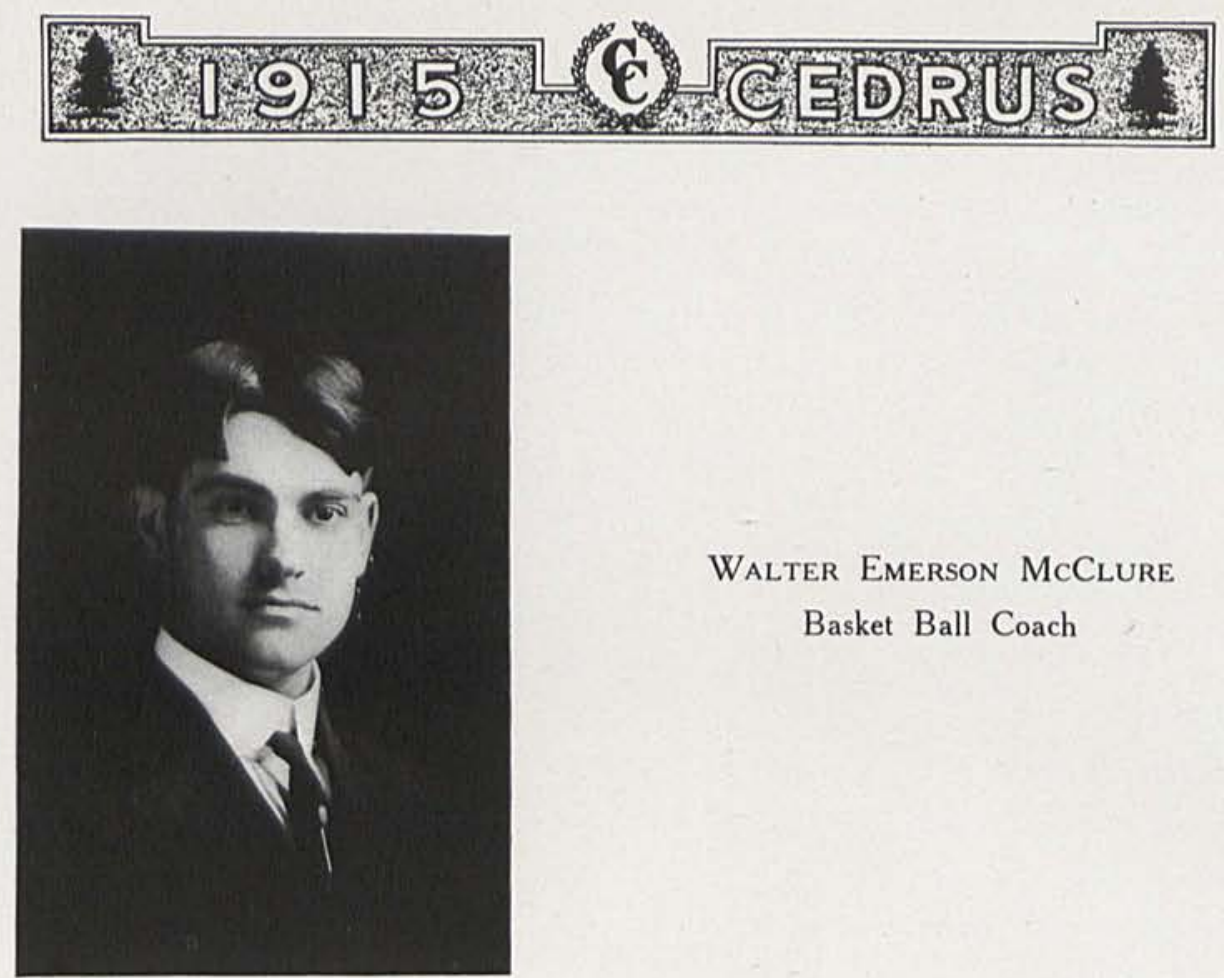

Walter EMERson McClure

Basket Ball Coach

John C. Grindle

Janitor

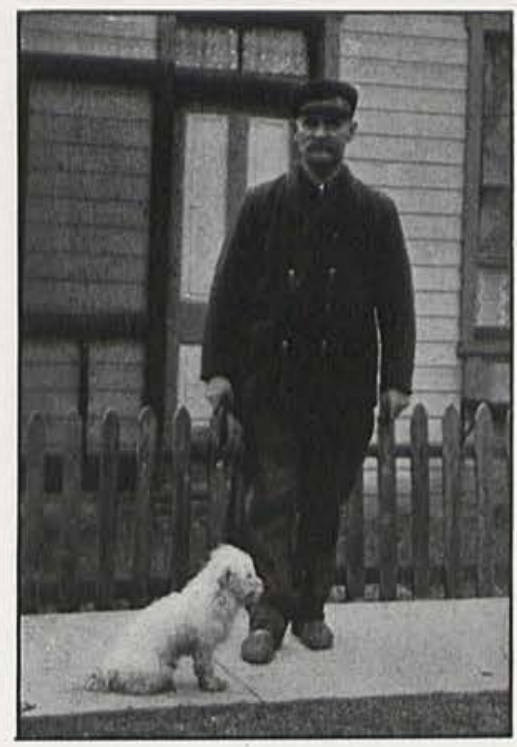



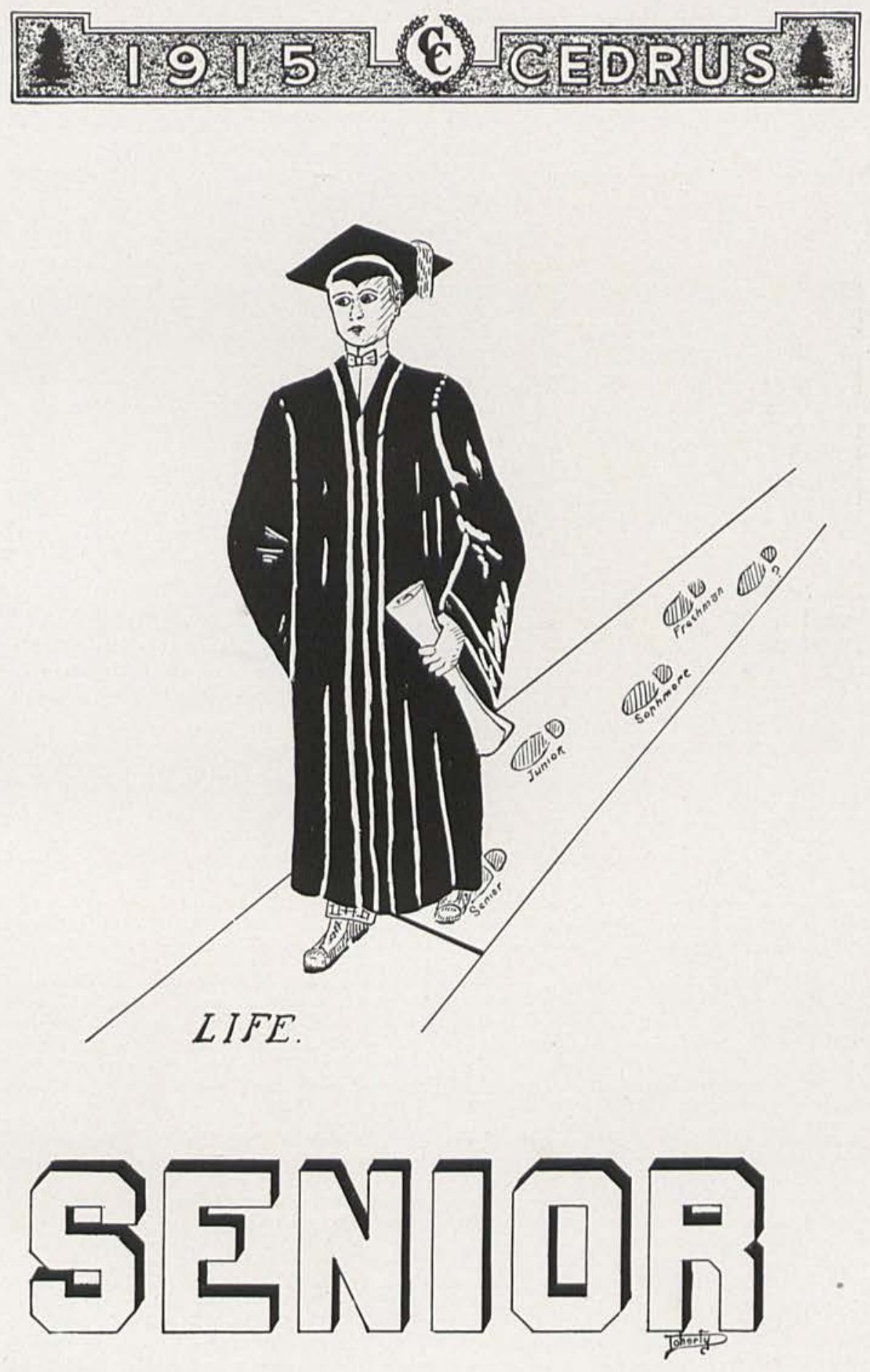


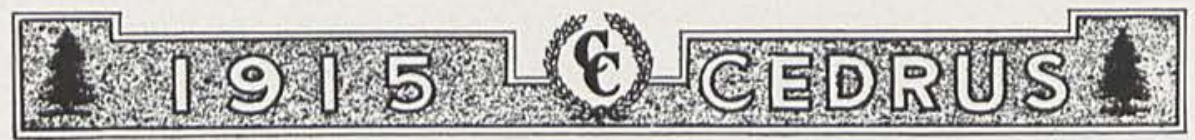

\section{Senior History}
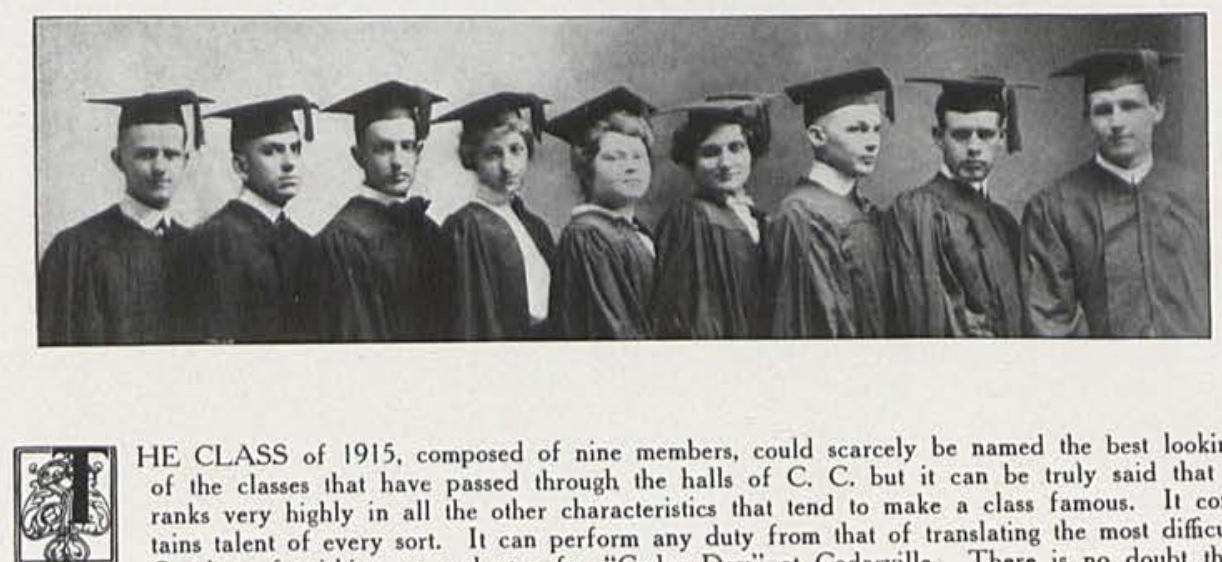

HE CLASS of 1915, composed of nine members, could scarcely be named the best looking of the classes that have passed through the halls of C. C. but it can be truly said that it ranks very highly in all the other characteristics that tend to make a class famous. It contains talent of every sort. It can perform any duty from that of translating the most difficult tains talent of every sort. It can perform any duty from that of translating the most doubt that the class contains the "long" and the "short" of everything.

Of the nine members of the class of 1915, two have come from the department of music-Creswell and Connor; the other seven-Spencer, Bird, Sterrett, Ross, Loyd, Burns, and McCorkellhave come from the collegiate department proper. They have majored in the departments of Chemistry, Education, Psychology, and Missions. All of the seven have taken the greater part of their work at Cedarville, and will graduate with the degree of "Bachelor of Arts."

Four years ago the present Senior class, Freshman then of course, numbered sixteen. Since that time some of them have dropped out to take up their work at other institutions. Some have entered the teaching profession, while others graduated from Cedarville in the class of 1914. Although the the teaching profession, while others graduated from to make itself representative of merit and ability. The beginning it made in the recitation rooms of Cedarville College will never be forgotten.

It is scarcely necessary to say that the class of 1915 will never be forgotten by the faculty, who have labored so patiently to mold the various members into vessels of honor. The material with which they have had to work was of such a quality that they found it a delight to open their class-room which they have had to work was of such a quality that me parious members of this class. We as a class, wish doors every day and look upon the faces of the various members of this class. Whe have thus helped to use a part of this space to extend our appreciation and thanks to all those who have thus helped us out of the mire of ignorance, and from when
along through the years of our college course.

However, these are not all the marks of distinction the class of 1915 has left behind it. From he very first it has taken an important part in the activities of "Cedar Day." Every year the stunts pulled off by this class have taken the cake. Those who witnessed it will remember the trip taken

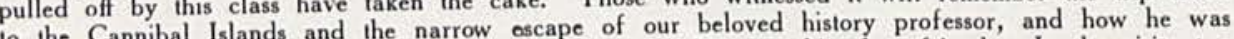
rescued by a squadron of girls who to this day are listed among his close friends. In the visit at a rescued by a the teaching proHoosier school there were a number of good points the display of the largest warship afloat, "The fession: and last year the crowd was astonished will have to call this great ship into service as it is Junior." It is thought that President Wilson will have to call "Senior." That this class has furnished the "ship of state." Recently, it has changed its name to the "Senior." That this class has furnished one of the orators for "Cedar Day" will also be remembered. The oration delivered by our President, Cameron Ross, was worthy of commendation. We are sure that the eating capacity of lass at the "Cedar Day" picnics has never been surpassed. It has become a law that a double portion must be placed before them, if their appetites are to be satisfied. 

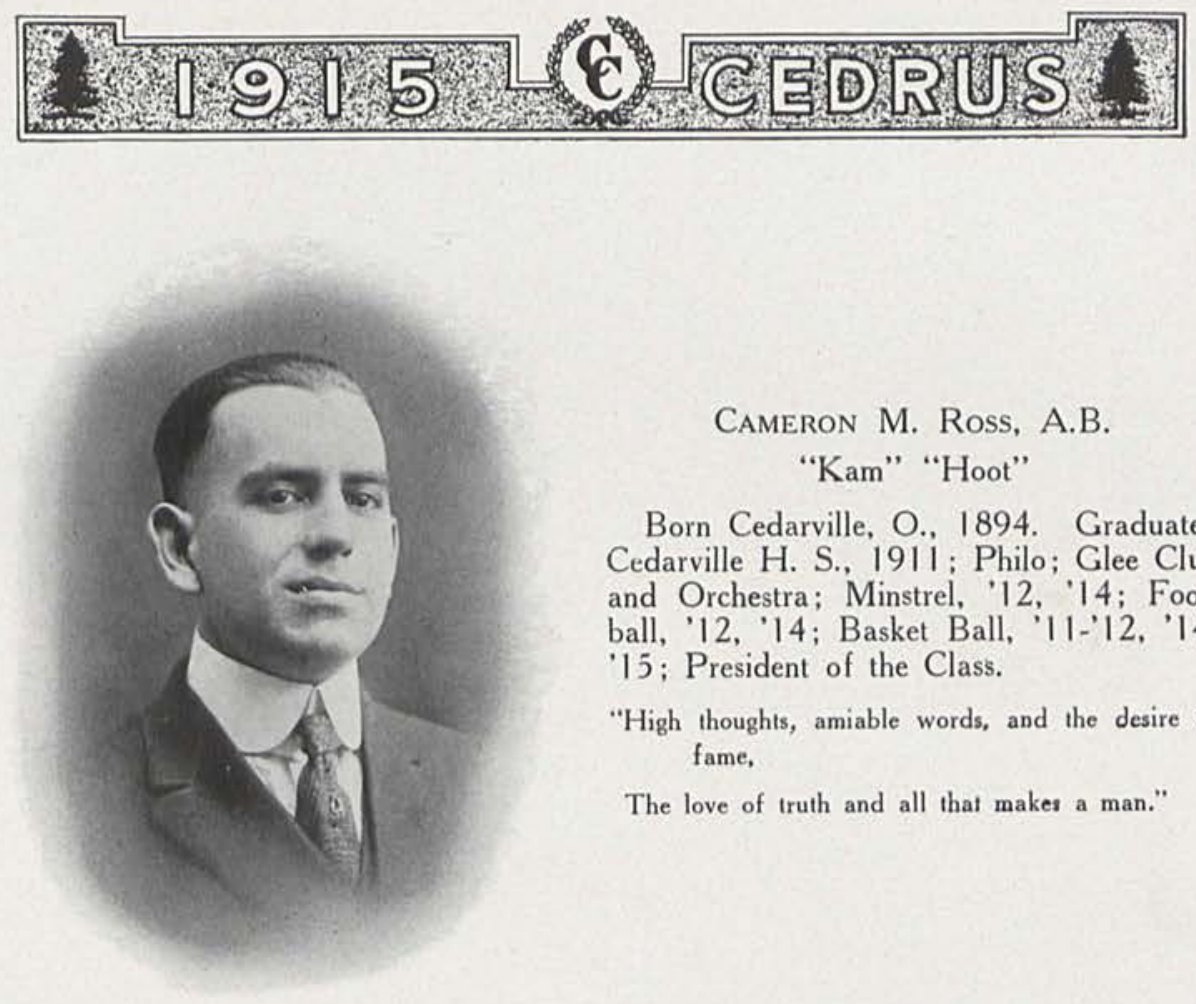

\author{
Cameron M. Ross, A.B. \\ "Kam" "Hoot"
}

Born Cedarville, O., 1894. Graduated Cedarville H. S., 1911: Philo; Glee Club and Orchestra; Minstrel, '12, '14; Football, '12, '14; Basket Ball, '11-'12, '1415; President of the Class.

"High thoughts, amiable words, and the desire of fame,

The love of truth and all that makes a man."

\section{Wilmah Spencer, A.B.}

"Billie"

Born Cedarville, O., 1893. Graduated Cedarville H. S., 1911; Philo; President, Y. W. C. A., '14-15; Instructor in Algebra, '14-'15; Secretary of the Class.

"Her care was never to offend,

And every creature was her friend." 

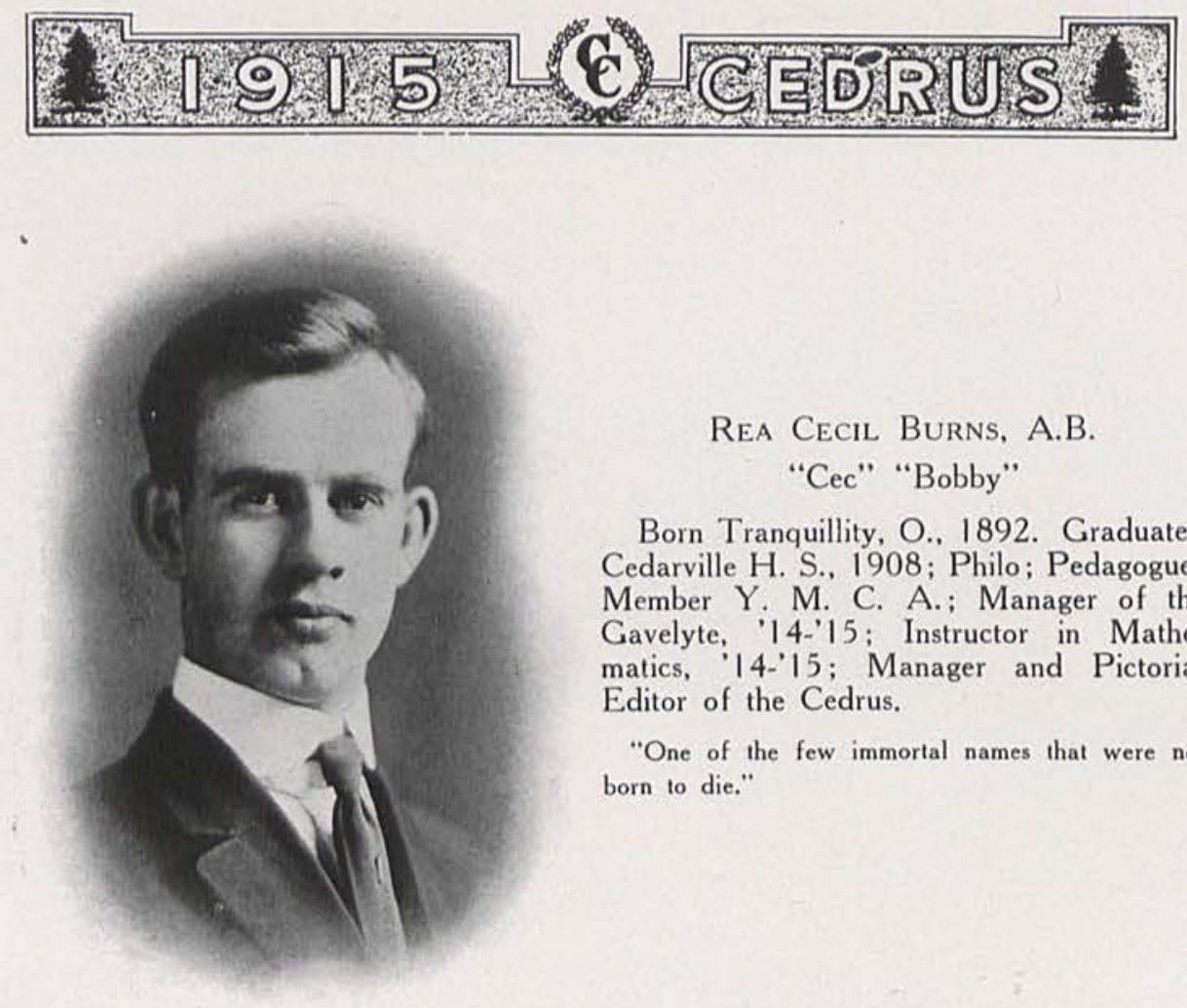

\author{
Rea Cecil Burns, A.B. \\ "Cec" "Bobby"
}

Born Tranquillity, O., 1892. Graduated Cedarville H. S., 1908; Philo; Pedagogue; Member Y. M. C. A.; Manager of the Gavelyte, 14-15; Instructor in Mathematics, '14-'15; Manager and Pictorial Editor of the Cedrus.

"One of the few immortal names that were not born to die."

\title{
Helen Creswell \\ "Helen"
}

Born Cedarville, O., 1895. Graduated Cedarville H. S., 1913; Department of Music.

"Her hair is auburn, of that Titian tint So seldom seen in woman, save in print."

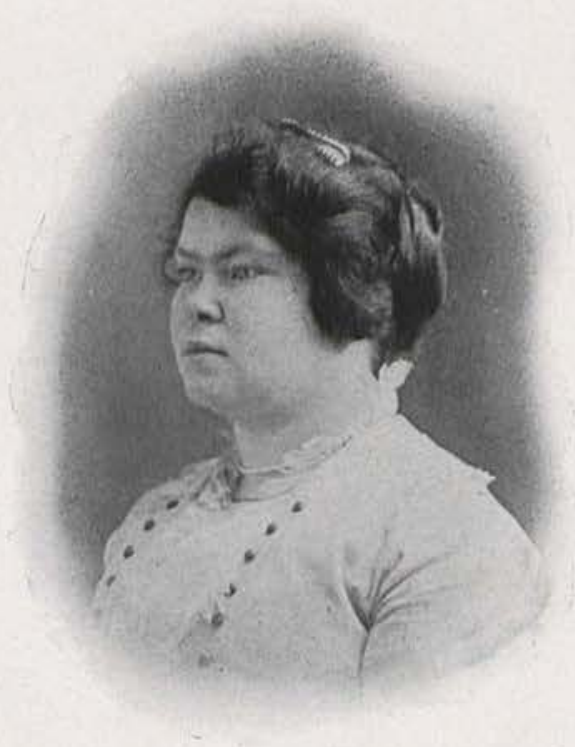



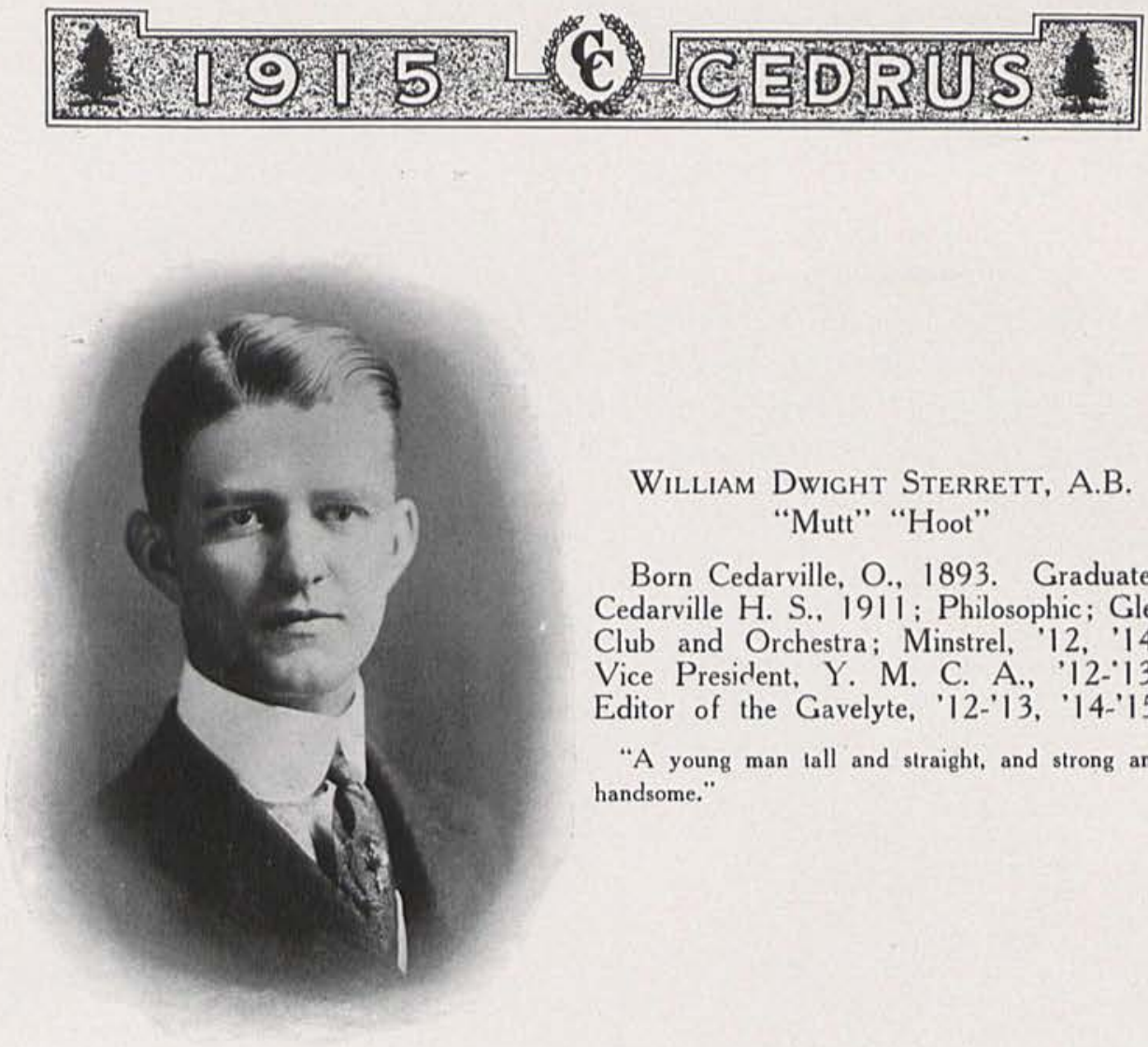

\section{William Dwight Sterrett, A.B. "Mutt" "Hoot"}

Born Cedarville, O., 1893. Graduated Cedarville H. S., 1911; Philosophic; Glee Club and Orchestra; Minstrel, '12, '14; Vice President, Y. M. C. A., '12-13; Editor of the Gavelyte, '12-'13, '14-'15.

"A young man tall and straight, and strong and handsome."

John Roscoe McCorkell, A.B.

\section{"Cork"}

Born Cedarville, O., 1892. Graduated Cedarville H. S., 1911; Philo; Orchestra and Clee Club; Assistant Manager, Min. strel, 12; Manager, Minstrel, '14; Vice President of the Class.

"A valiant youth, and his face like the face of the morning,

Gladdened the earth with its light, and ripened thoughts into action."

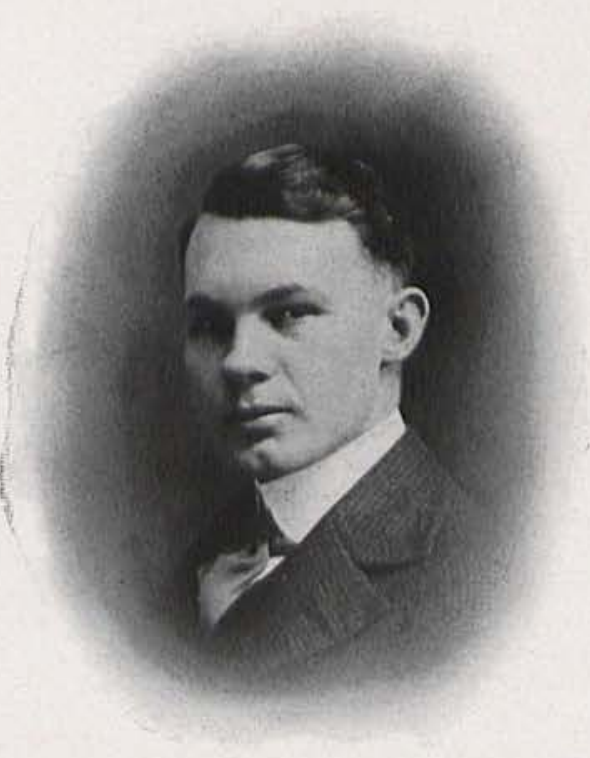




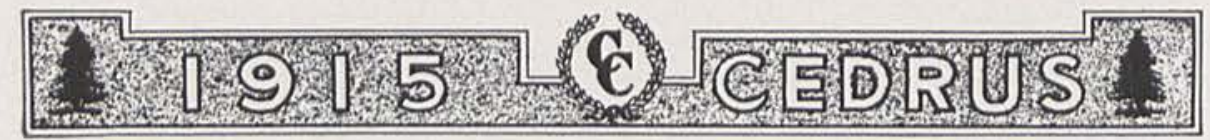

\section{Harry Freeman Bird, A.B. \\ "Birdie"}

Born Cedarville, 1892. Graduated Cedarville H. S., 1911; Philosophic; Basket Ball, '12-'13, '15-'15; Football, '11, '14; Y. M. C. A. Cabinet, '13, '14, '15: Gavelyte Staff, '14-'15.

"Honest and brave, kind and courteous, faithful and true, are the qualities that are found in you."

\section{INEZ ERMA CONNER \\ "Inez"}

Born Jamestown, O., 1893. Hickory Grove H. S. Department of Music.

"Sweet simplicity is thine:

You please, yet never strive to shine." 

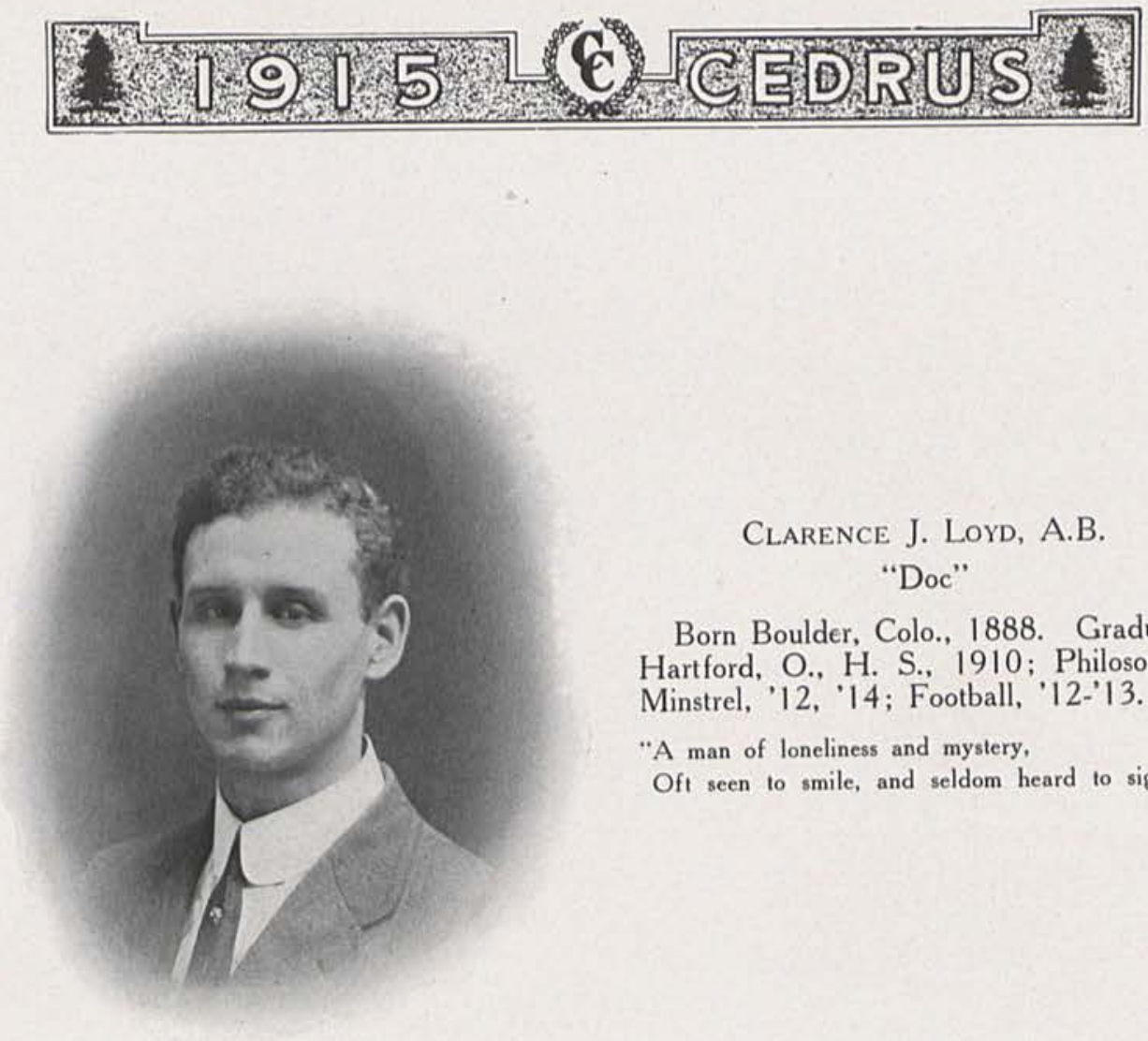

\section{Clarence J. Loyd, A.B. \\ "Doc"}

Born Boulder, Colo., 1888. Graduated Hartford, O., H. S., 1910; Philosophic; Minstrel, '12, '14; Football, '12-'13.

"A man of loneliness and mystery,

Oft seen to smile, and seldom heard to sigh."

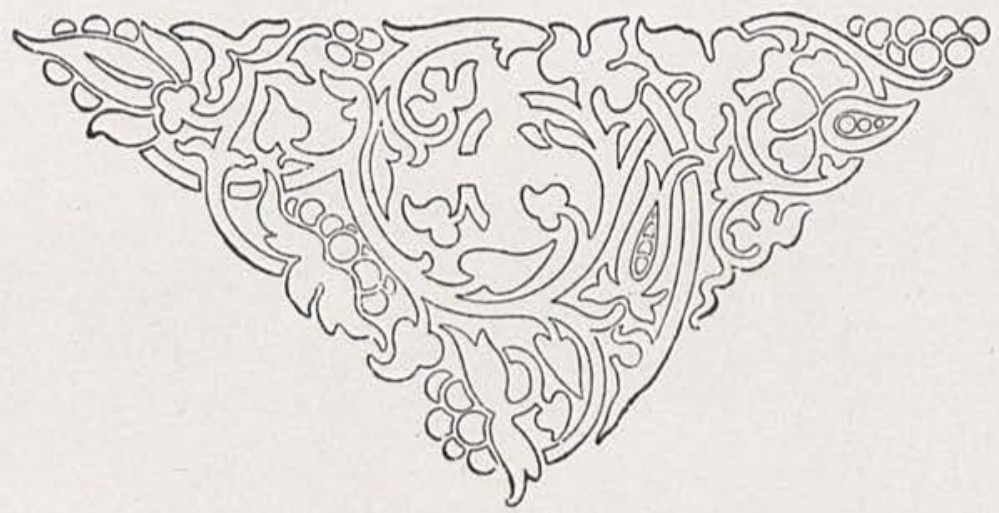



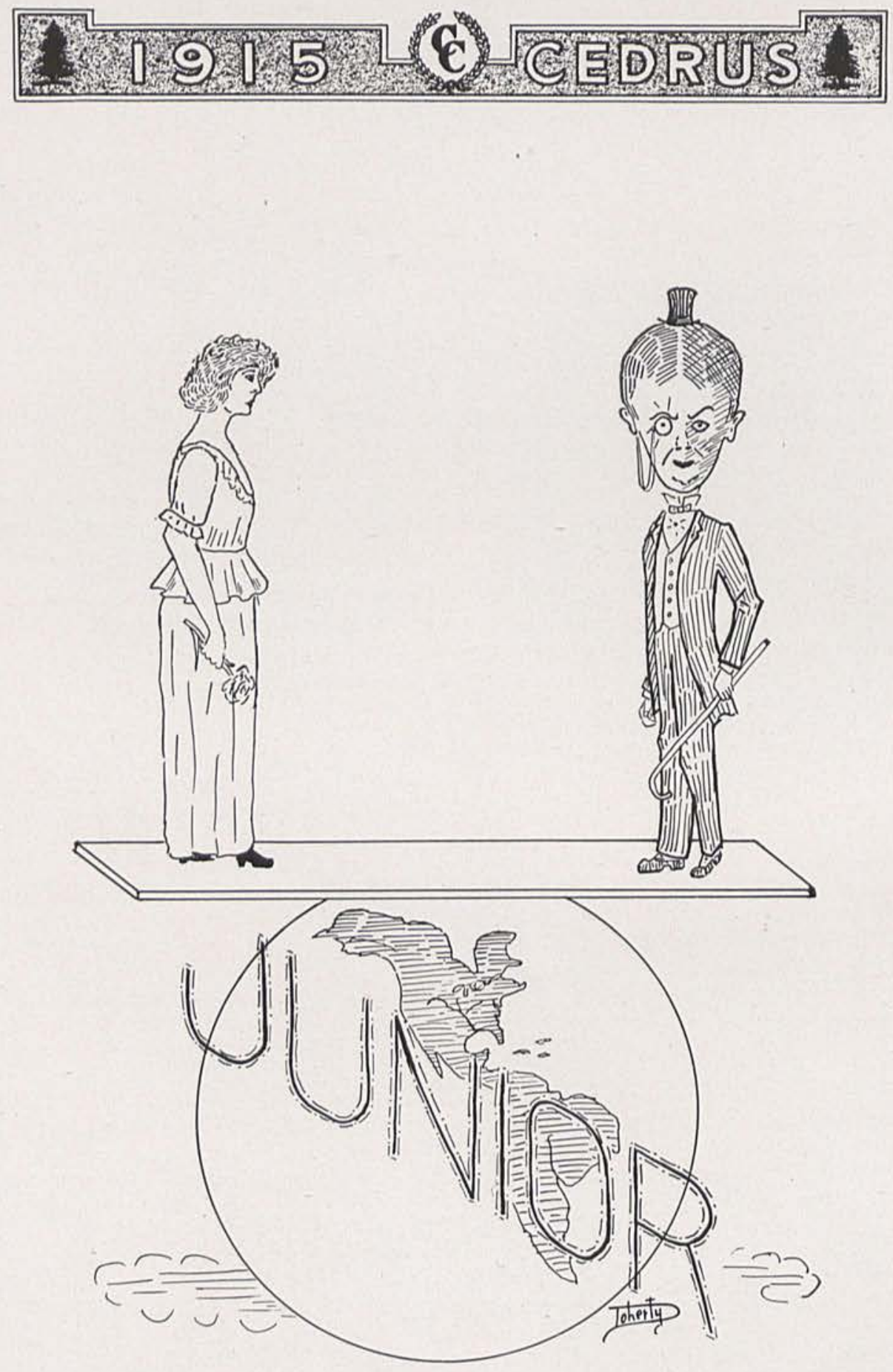


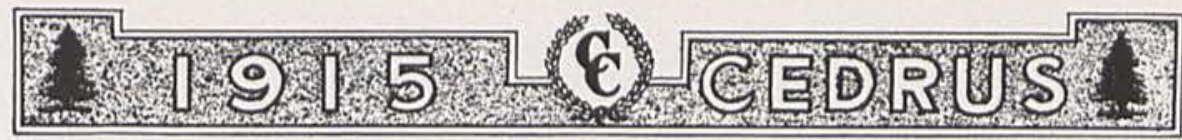

\section{The Juniors}

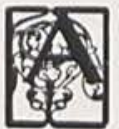

S I took up my pen a little Brownie appeared before my lingering gaze and perched himself on the top of my pen. Wonderingly I inquired, "And where did you come from, my little Sprite?"

"Ask no questions!" was the saucy reply, "I am here for business, to see that the noble Juniors get fair play!"

Now, to be candid, I had not expected to extol all the virtues of this wonderful (?) class-for truly they are many-because, you see, we have not yet reached the top round of the ladder and there is still just a little probability that the lofty Seniors may endeavor once more to send us into the pit of humiliation.

In describing the Junior class we would note, in the first place, its position. It is composed of nine divisions - or members - two of which may be united soon, though not as a result of war. These members are Ada Wallace, Mary Bird, David Bradfute, Orland Ritchie, Carey Ritchie, William Hastings, Merle Rife, Paul Ramsey, and ye Historian. We are bordered on the north by the Seniors, on the east by the Faculty, on the south by the Sophomores, on the west-well, that region is yet unexplored. Now, we take the history of the class: its accomplishments and its endeavors the last three years-archaeology has as yet been unable to decipher the hieroglyphics of any previous history - we find some interesting data.

In the fall of 1912, twenty-four young men and maidens, just graduated from high school, entered the Freshman class. Never did a more congenial, jolly, yet studious class of young people enter the college halls. Yes, the Sprite reminds me, it was the largest too. Never did trade wax so great for the baker, the pickle, and meat men as it did that year-wiener sandwiches and pickles are but a synonym for "spread."

Never did Sophomores so utterly fail in an attempt to play the role of Upper Classmen. Never was Professor Jurkat's temper so sorely tried (he is floor walker at school) and the Sprite adds, "Never were teachers so well pleased with class grades." (?)

Reluctantly we grew out our Freshman togs and assumed the role of Sophomores. It sobered us somewhat to assume so dignified a name. We had to sacrifice many things; our spreads especially. There was but one the entire year, and we were permitted to have only ice cream and cake.

Last fall when the college doors swung open and we entered into our Junior year we found that the ranks had been thinned until only nine remained. May the ties of fellowship and loyalty for our college bind us together until we have finished our college course.

We now wish to mention a few of the characteristics of the members of this class. Intellectually, we are the Seven Wonders of the world with two duplications. As logicians, some of the class have no rivals. As ethicists, some have declared their intention of succeeding Gregory. As scientists, one of our members is assistant professor in the science department. As mathematicians, all the mathematics that Cedarville College can boast of has been mastered. As students of the languages, anyone desiring a tutor in French would do well to inquire for Mesdemoiselles Bird and Wallace. Another member of the class converses in Egyptian, Hebrew, Greek, Latin, Spanish, German, and sometimes, English. As musicians, some of our members are quite proficient, nay, might be termed geniuses. Still another member of the class, although we have always known he expected to be an agriculturist, is making a specialty of gardening. The Sprite says he is because he has a Gardiner.

I had but begun to expatiate on our athletic ability, when "Nuf Sed," snapped our Sprite. As I am rather uncertain of his meaning, and fear to question him lest we lose his friendship I shall bring this history to a close.

The Sprite bids you all farewell. 

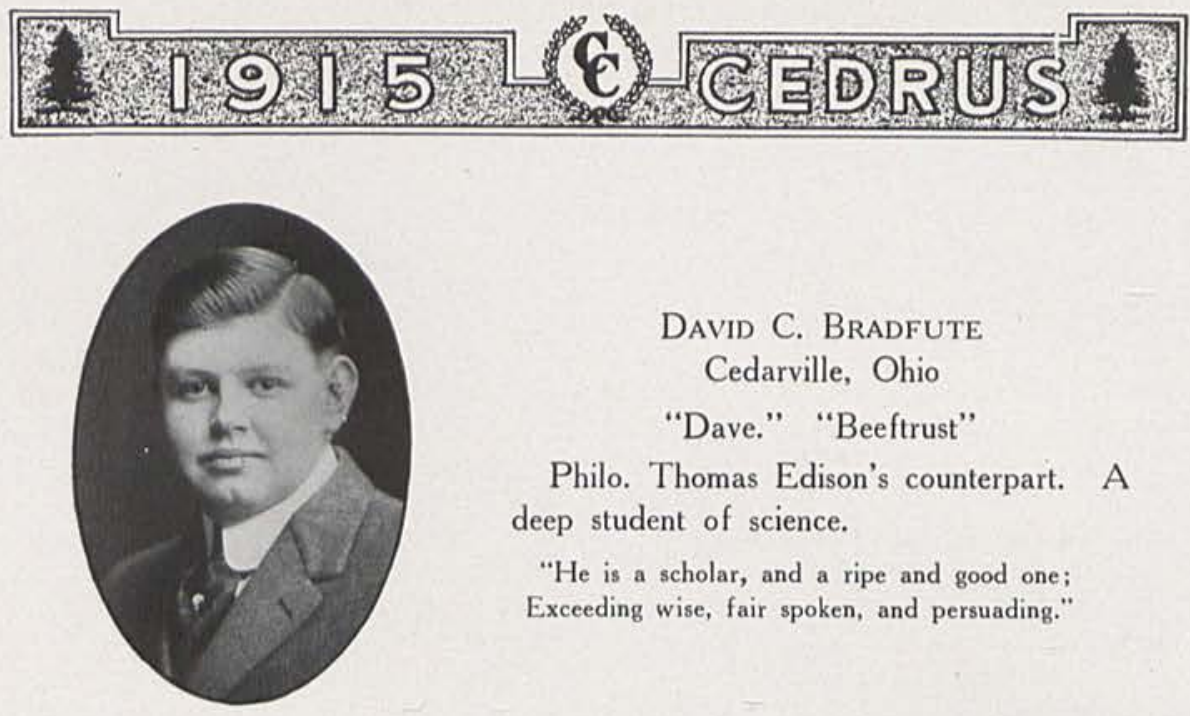

\section{David C. Bradfute \\ Cedarville, Ohio \\ "Dave," "Beeftrust"}

Philo. Thomas Edison's counterpart. A deep student of science.

"He is a scholar, and a ripe and good one; Exceeding wise, fair spoken, and persuading."

\section{MARY BIRD \\ Cedarville, Ohio \\ "Fraulein Vogel"}

Philo. Custodian of the Records. Jolly. A good student. Carey's favorite b(B)ird.

"A face more fair, a form more sweet,

Ne'er hath it been my lot to meet."
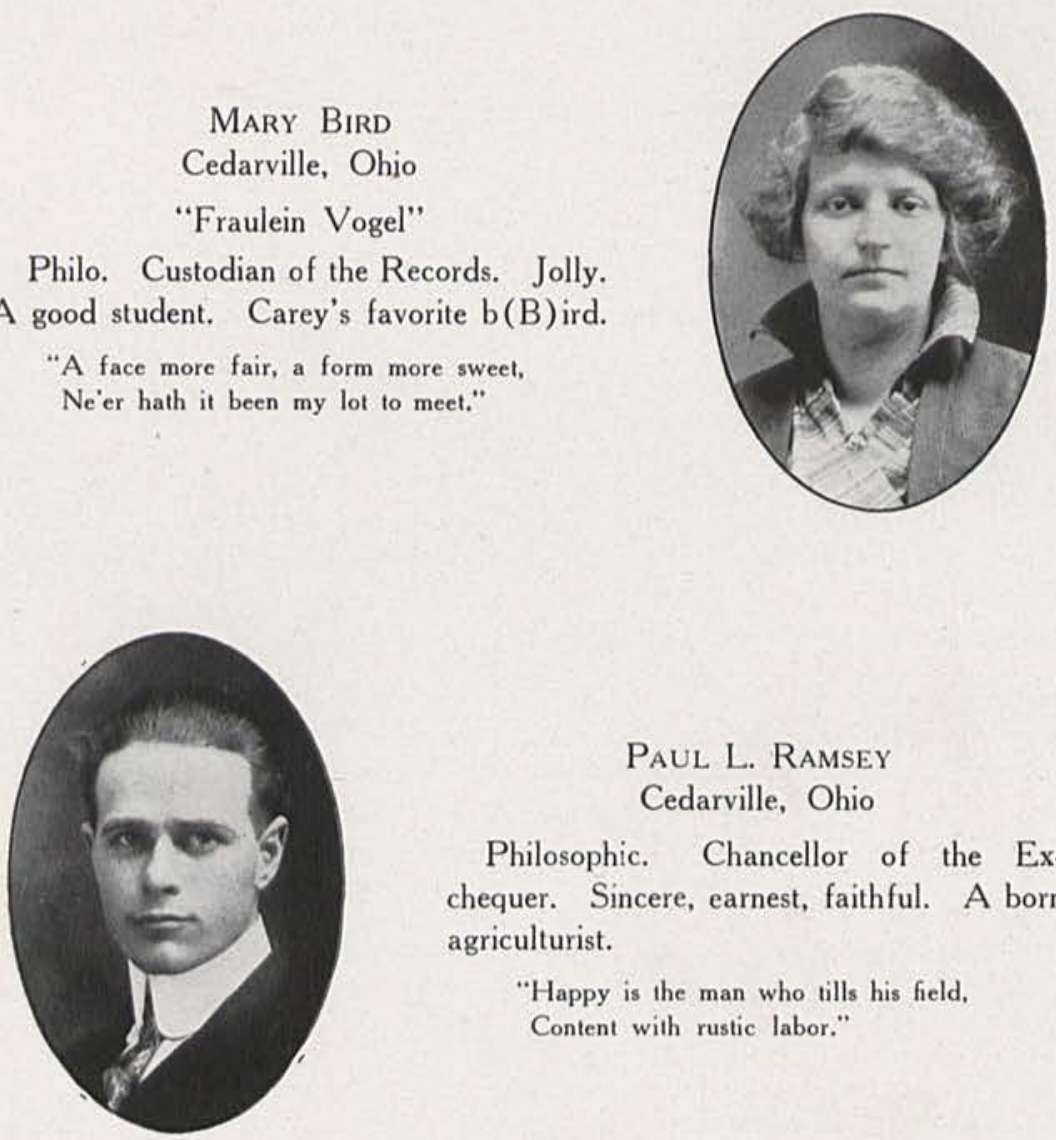

Paul L. Ramsey

Cedarville, Ohio

Philosophic. Chancellor of the Exchequer. Sincere, earnest, faithful. A born agriculturist.

"Happy is the man who tills his field,
Content with rustic labor," 

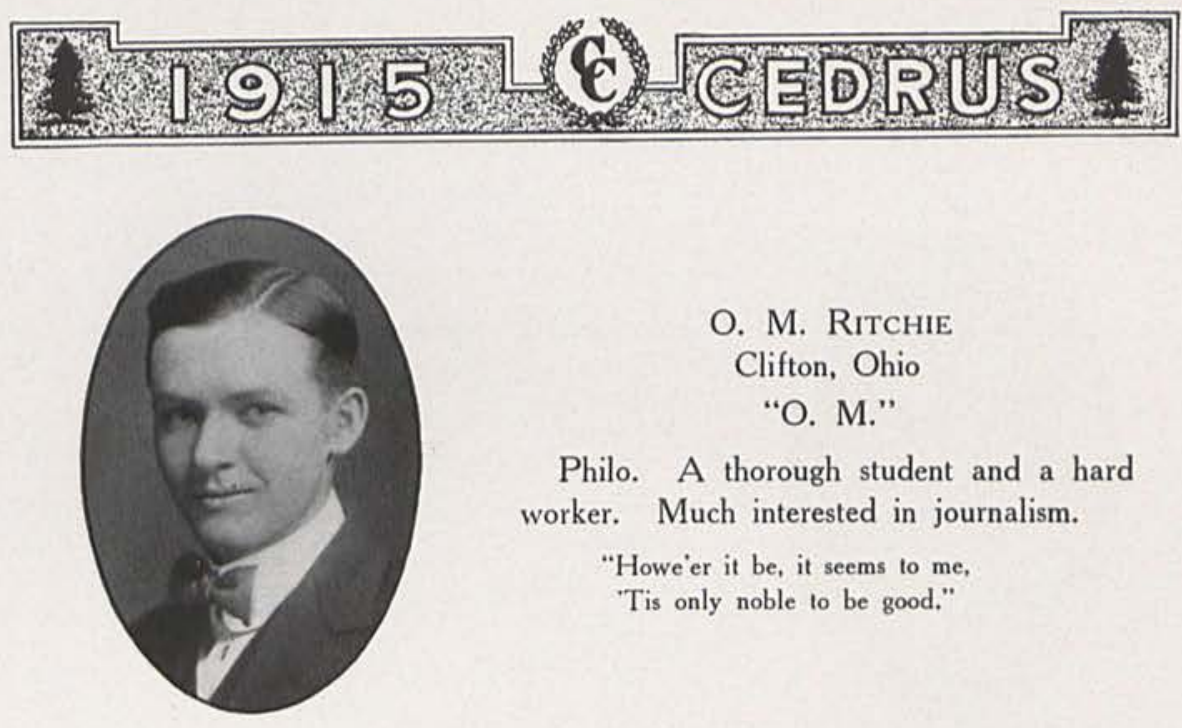

\author{
O. M. Ritchie \\ Clifton, Ohio \\ "O. M."
}

Philo. A thorough student and a hard worker. Much interested in journalism.

"Howe'er it be, it seems to me,

"Tis only noble to be good."

\author{
AdA F. WALLACE \\ Winchester, Ohio \\ "Ader." "Adams County"
}

Philosophic. A charming maiden with golden hair. Very modest in her ways.

"And her modest answer and graceful air

Show her wise and good as she is fair."
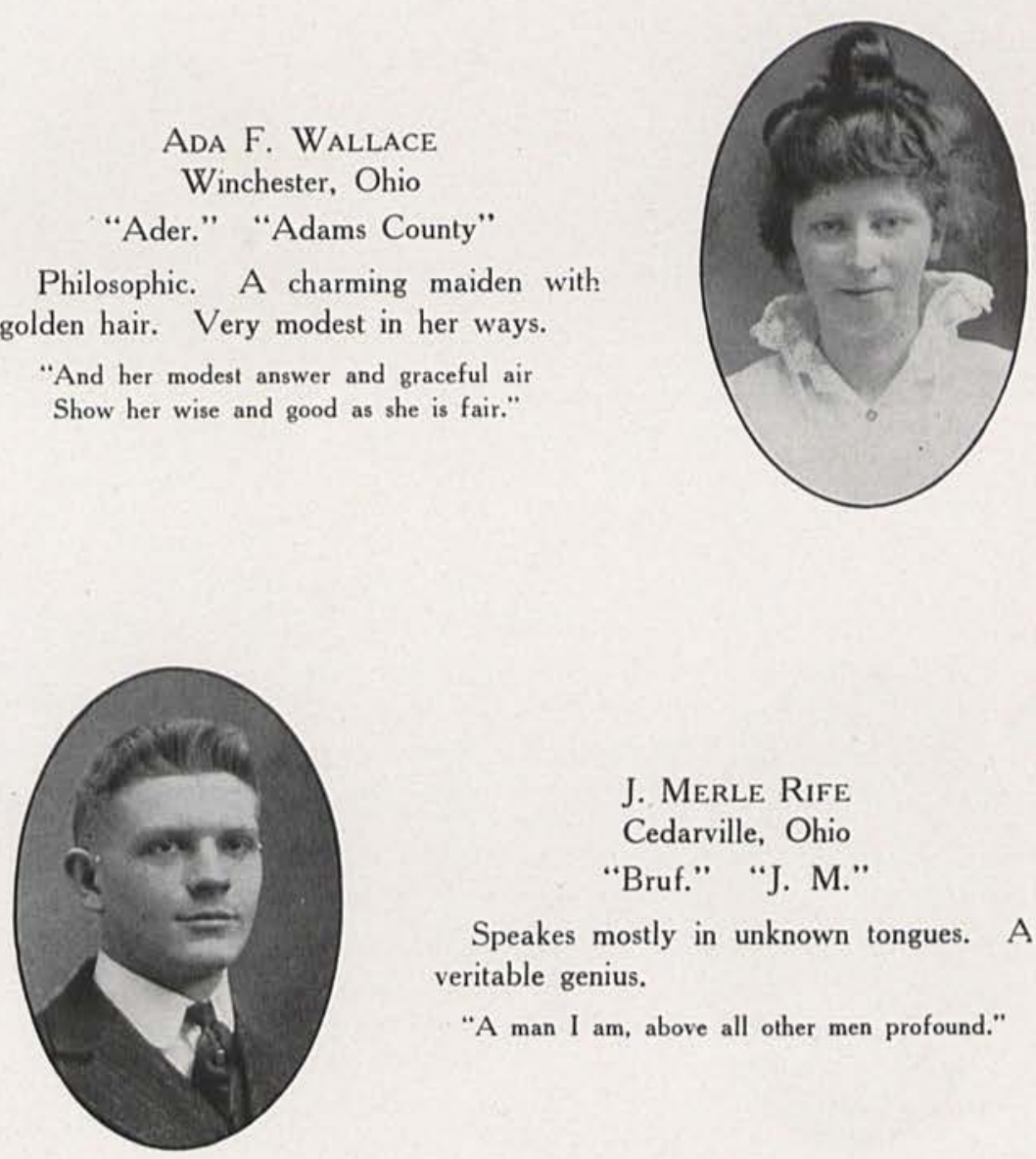

\title{
J. Merle Rife \\ Cedarville, Ohio \\ "Bruf." "J. M."
}

Speakes mostly in unknown tongues. A veritable genius.

"A man I am, above all other men profound." 

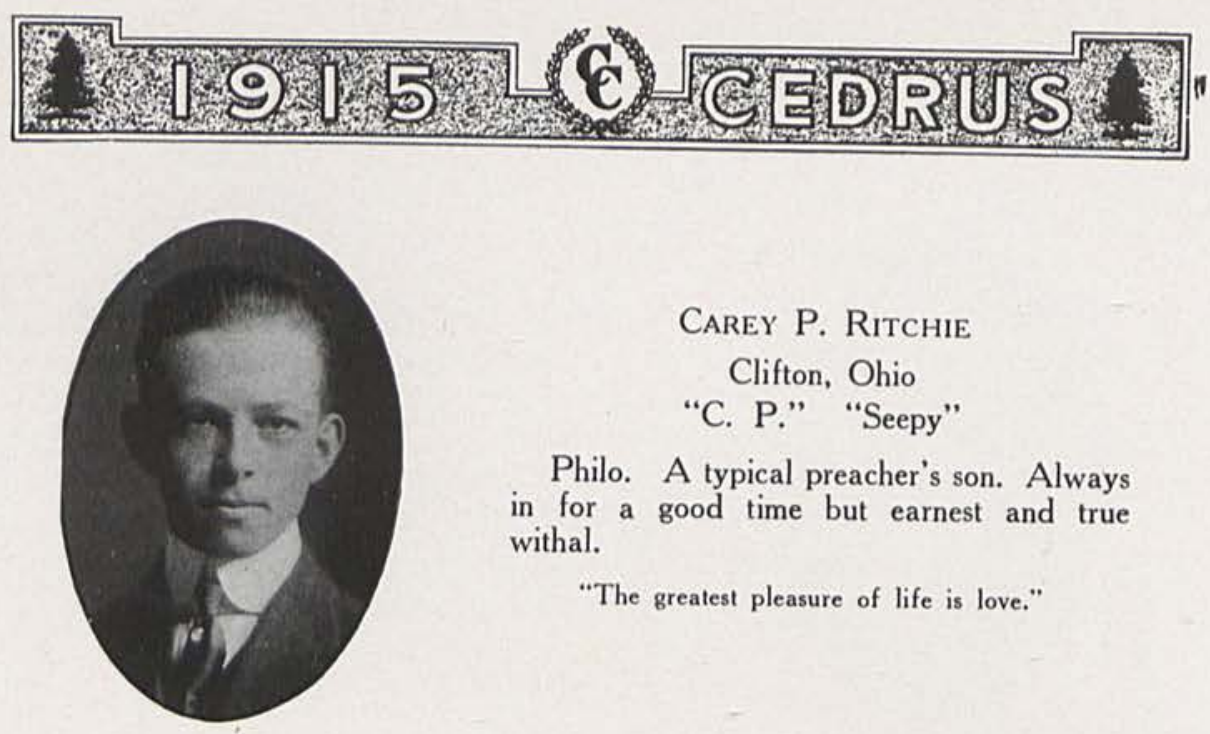

\author{
Carey P. Ritchie \\ Clifton, Ohio \\ “C. P." "Seepy"
}

Philo. A typical preacher's son. Always in for a good time but earnest and true withal.

"The greatest pleasure of life is love."

\title{
Dorothy Collins \\ Cedarville, Ohio \\ "Dot." "Dimples"
}

Philo. Much devoted to her work she does all things well.

"So well to know

Her own, that what she wills to do or say

Seems wisest, virtuousest, best."
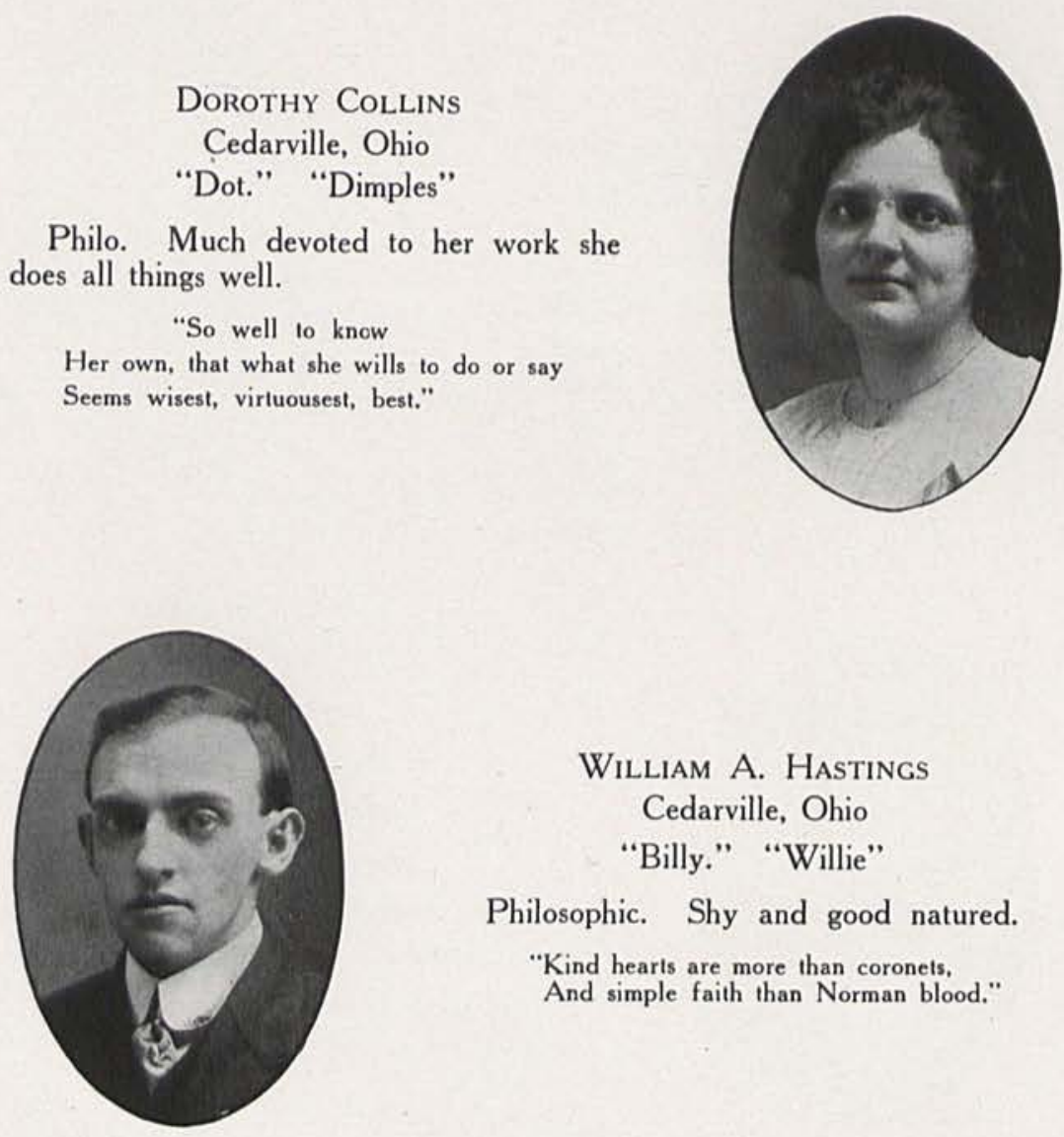

\author{
William A. Hastings \\ Cedarville, Ohio \\ "Billy." "Willie"
}

Philosophic. Shy and good natured.

"Kind hearts are more than coronets,

And simple faith than Norman blood." 

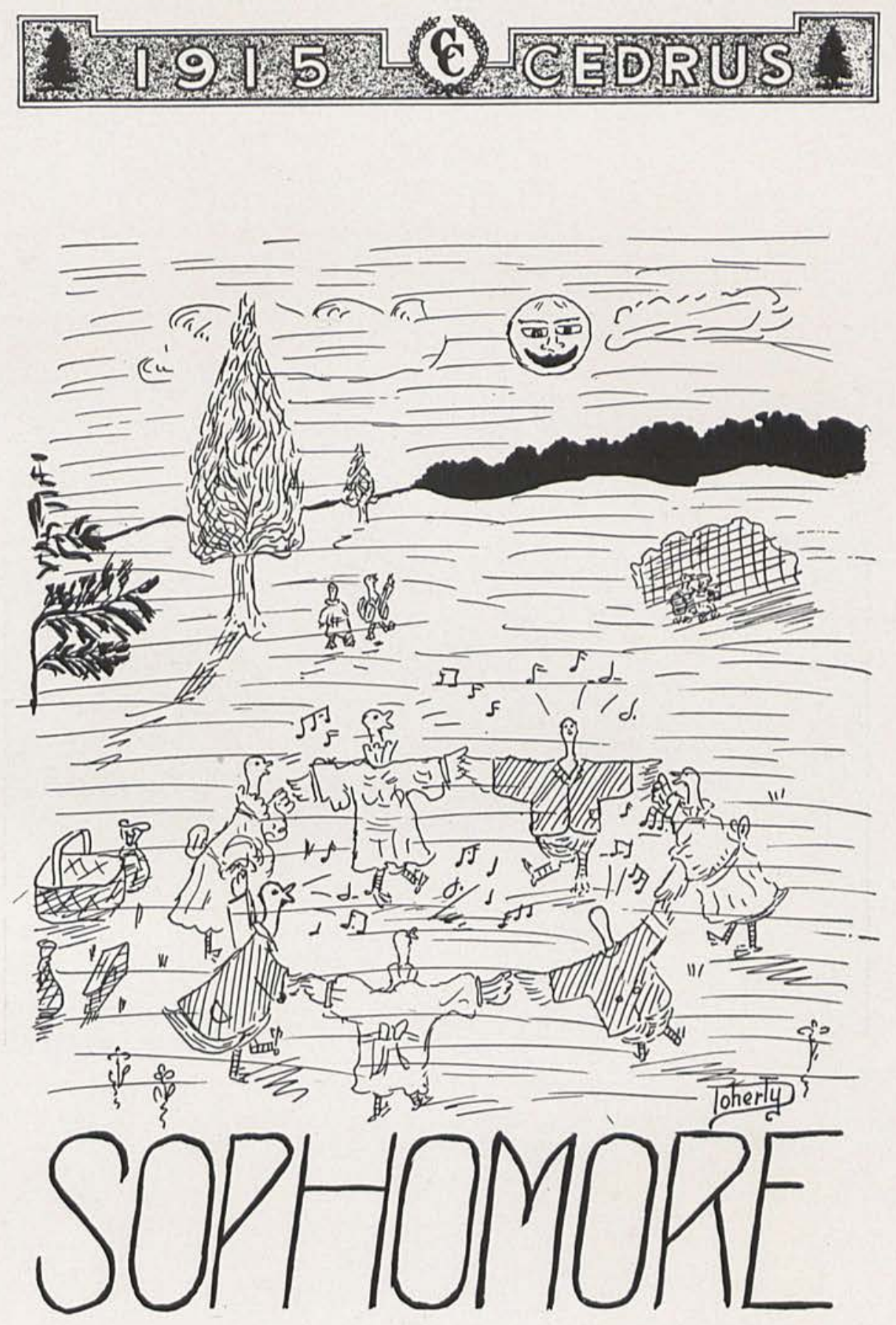

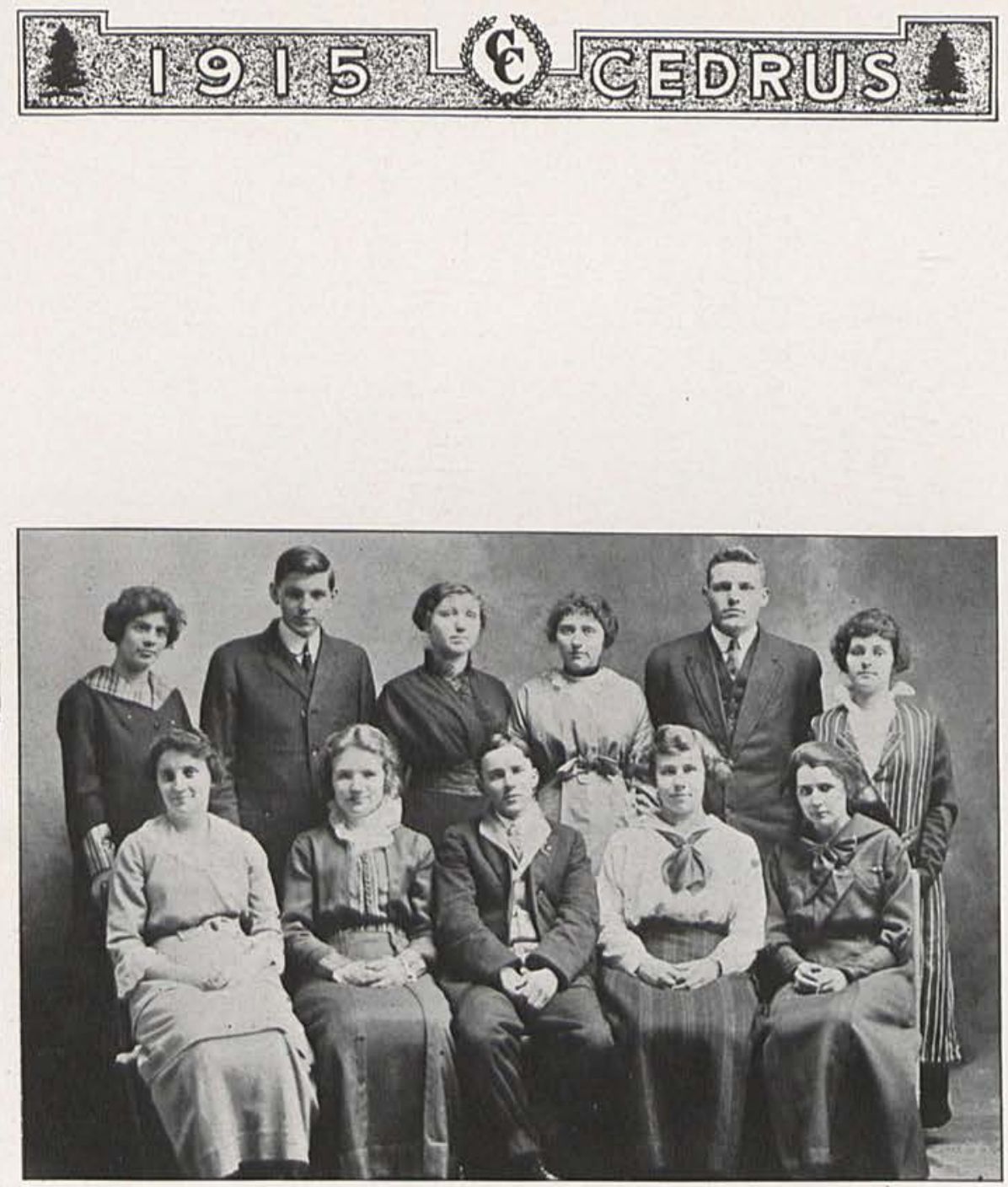

SOPHOMORE CLASS

Standing: Burns, Elder, Somers, Gardiner, Collins, Harris.

Sitring: Mendenhall, Creswell, Weaver, Stormont, Ramsey. 


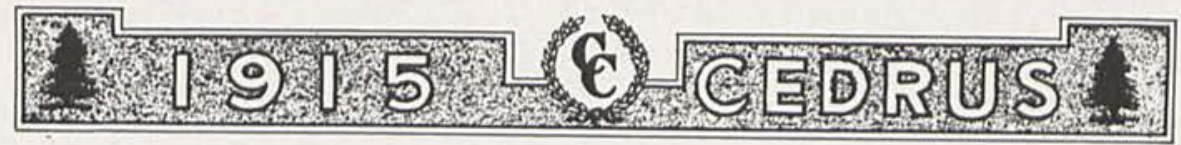

\section{Sophomore History}

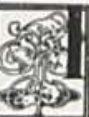

N THE fall of 1913, just when the trees were decking themselves with their beautiful colors, and all nature was sending out her "call to the wild," the doors of Cedarville College swung open for the twentieth year of college life, calling back former students and welcoming those who were for the first time to enter her halls. In answer to the call seventeen young men and women from various parts of the Buckeye and Keystone states enrolled as Freshmen. Undaunted by the threats of the Sophomores to make us enter by the side door, wear cute little green caps, and to make the feminine portion of the class wear their hair in pigtails, we soon proved that we were able to make good. And we made good in classroom, literary society and athletics. Don't you remember that the star player of the boys' basket ball team, and the center of the girls' team were members of this class? And then, didn't the "Elder" member win a prize in the Perry Centennial contest? Some of the other members were musicians, some were readers, and the remainder, having no special talents, just filled up cracks, and cheered for the talented ones. Class spreads were never dull, for we were a jolly bunch and we usually had plenty of "Fudge." True we added our share to the worry of the faculty, but were usually "squelched" by being asked to be a little quieter, the request being accompanied, sometimes, by a sound resembling a peal of thunder, but which we learned was only Professor Jurkat's foot rather suddenly coming down upon the floor. Two of the members because of ill health were forced to break the ranks, but the other fifteen marcher on, encouraged by the thought that some day they would be Sophomores,

With the opening of the next college year only seven of the fifteen came to claim that privilege. Some, having decided to take up other lines of work, are proving their ability there just as they did in college life. Four members were added however, and, aided by these, we are still keeping up our reputation. The captains of both basket ball teams of 15 are members of our class, as well as two forwards and a guard of the girls' team. Nor are we falling behind in the classroom; for with plenty of "Somers," a diligent "Gardiner," and an "Elder" to rule over us, we are kept in a flourishing condition, and are ever endeavouring to make "Onward, upward," our motto still, "As we follow close the leading of our dear old Cedarville." 

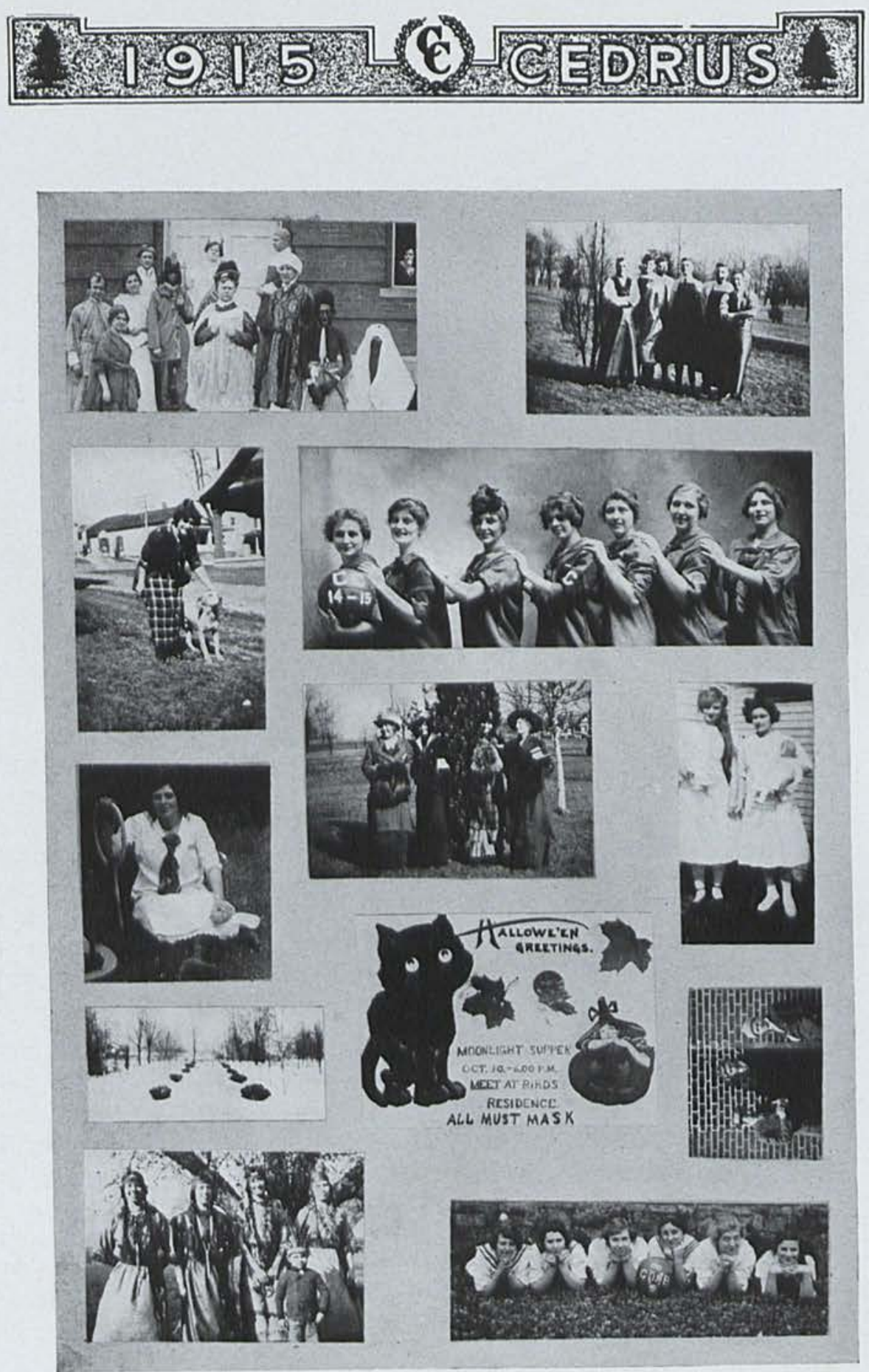

Glimpses of College Life 

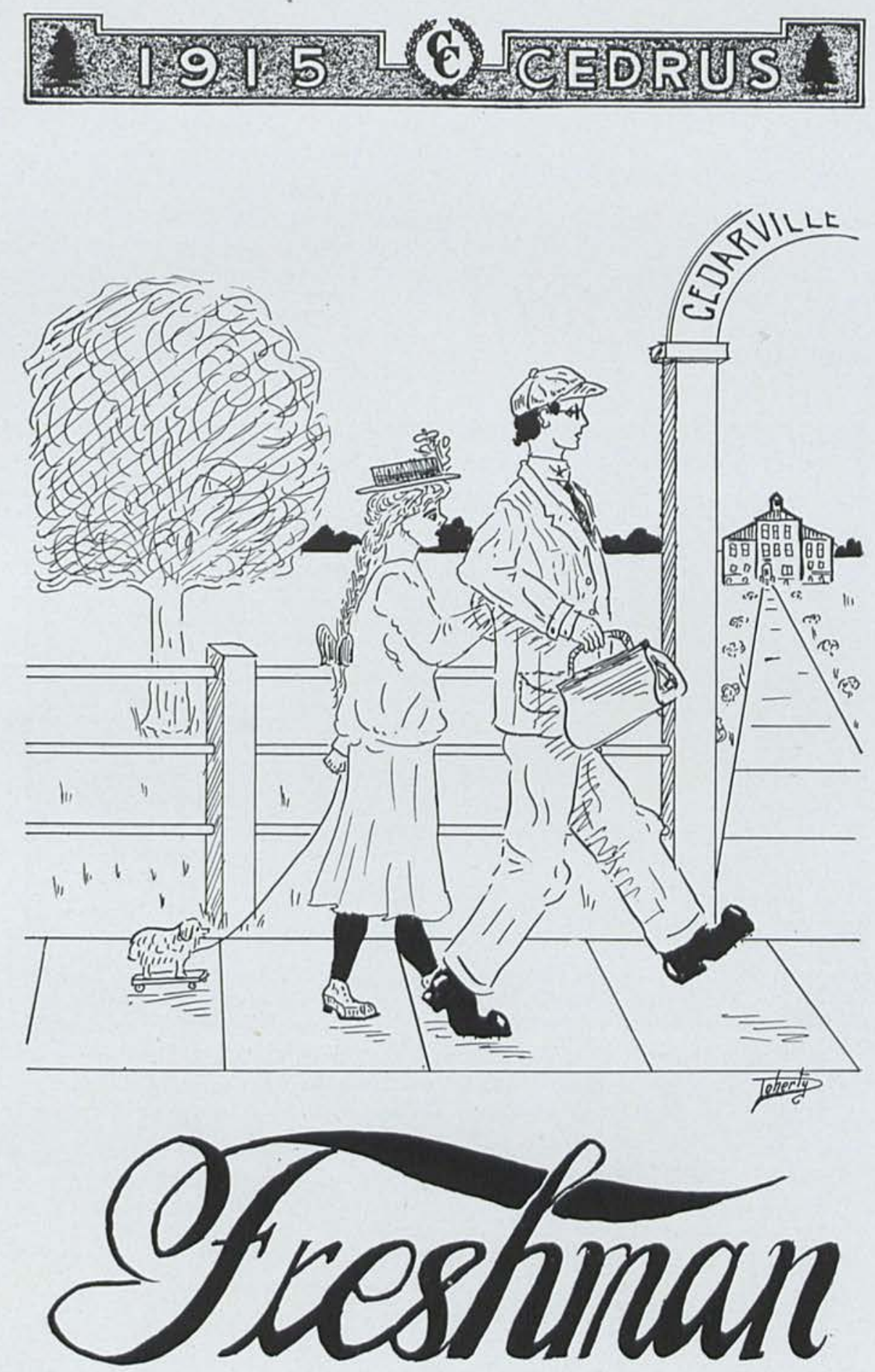

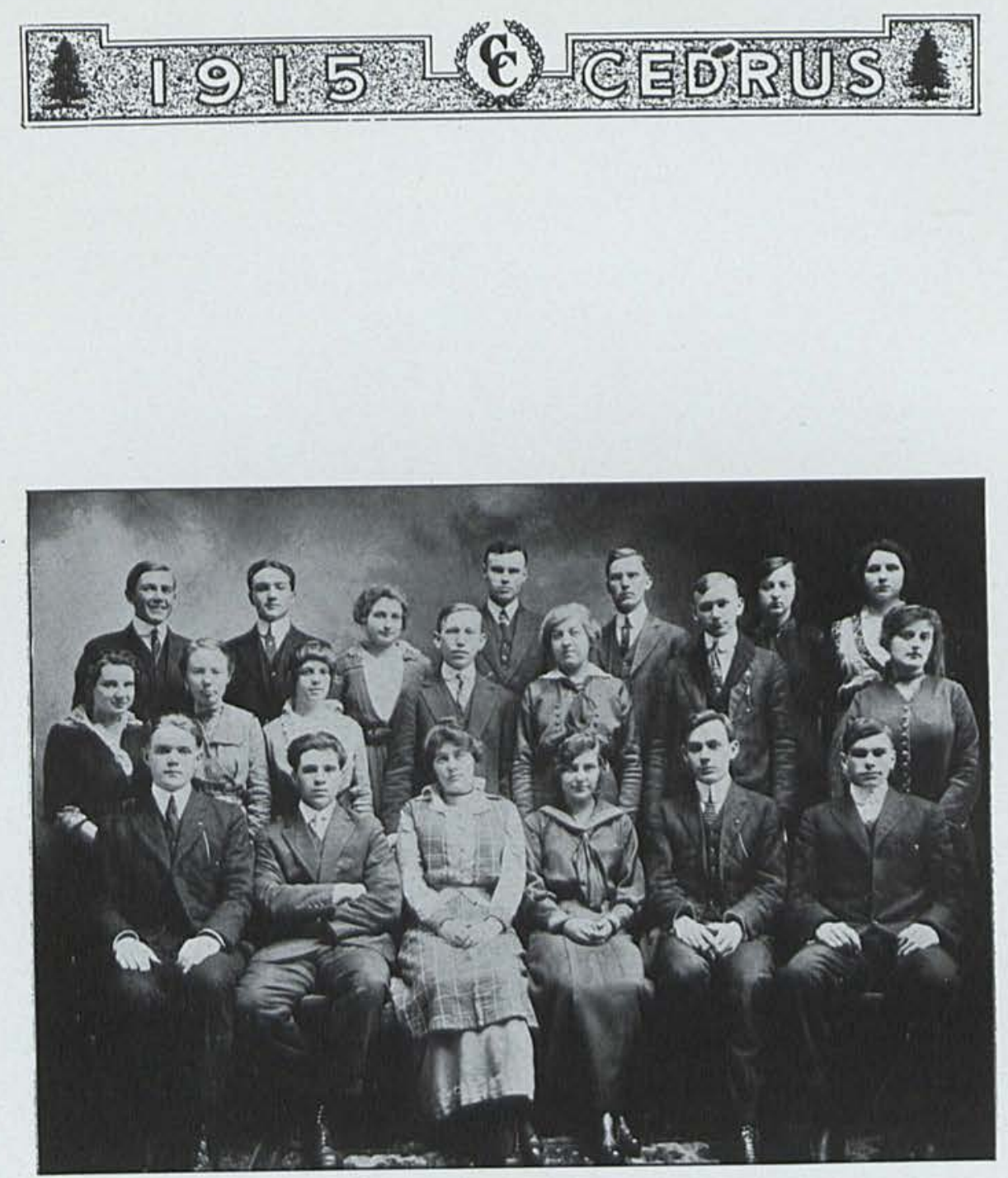

BACK Row: Short, Hutchinson, Baumgardner, Duff, Clark, Graham, Little.

Midple. Row: Northup, McCampbell, Shiplett, McMillan, Oglesbee, Boase, Collins. Bоттом Row: Chesnut, Hoskinson, Corry, Wright, Doherty, McClure. 


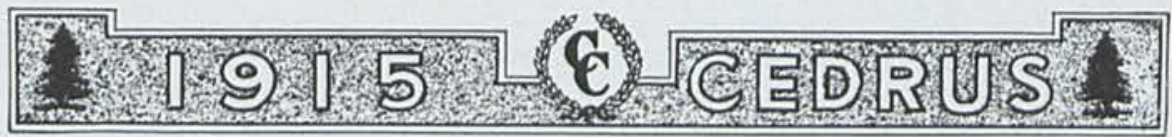

\section{Freshman History}

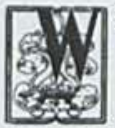

E. THE members of the Freshman Class, in order to create the best of impressions, procure justice, insure domestic tranquillity, provide for a common defence against Upper Classmen, and secure the blessings of publicity to ourselves and our Alma Mater, do compile and publish these facts concerning the Class of 1918.

We are twenty-one. Among these twenty-one are some of the gayest lads and prettiest lassies, some of the best athletes and most talented musicians, some of the best orators and students, and some of the brightest heads of hair to be found in the whole college.

How do we know this, and how can we prove it to the world at large? Only a fleeting glance at the accompanying picture is needed to verify the statement that our lassies are pretty. There are girls with blue eyes and brown eyes, with pompadour hair and with curls. There are tall girls and short girls, and girls thick and thin. There are blondes and brunettes; certainly, girls of enough different kinds to suit anyone's taste for beauty.

There is no doubt about the lads being gay, for "by their ties ye shall know them"; and surely there can be none gayer than "Cam's" famous pink one and "Jim's" reversible tango and purple.

Then, for proof of the athletic ability of our classmen, we have only to point to the pictures of both the girls' and boys' teams in basket ball. In each we find the smiling countenances of four noble Freshmen, who have proven their prowess by helping to make the winning easier, or the losing harder, in the season's battles for old C. C.

Does anyone doubt that we have musicians in our class? If so, let him stroll past Dr. Oglesbee's residence on Xenia Avenue some night, and listen to the happy and lilting strains of. "If I were a Bird," as the fair Helen executes them. Can he truthfully deny that th:s at least is a Freshman who has musical talent? Perchance on the same night the stroller may have passed McClure's room and heard the patriotic strains of "Yankee Doodle" issuing from his casement. Was not that talent also?

That we have the best orators does not need to be proven, for of the six contestants in the preliminarv oratorical contest four were Freshmen. and to one of these first honors were awarded. The judges who made the decision, have shown beyond a doubt. that the "Freshies" excel in the speech-making art.

Moreover. we are good students. This decision was not forced upon us by a few egotistical members. but bv the "Prof's" themselves. Greek and German, by hard riding, are to us sisht-reading; Latin constructions are mere res ludiendi; English is a pleasant iuggling with words; and Trig - well, let Trig be the unknown angle. Ours is indeed a bright class but perhaps the less said about our brightness the better: for as we have heard, red-headed people are as a rule anything but "slow to anger."

These are the merits with which we alone of all the classes, past or present, possess. Although we are not conceited, but modest and humble, we feel that when 1918 goes the way of all its predecessors

"It will leave behind it

Footprints in the sands of time;

Footprints that perhaps another,

Sailing o'er life's college main,

A forlorn and greener brother.

Seeing may take heart again." 

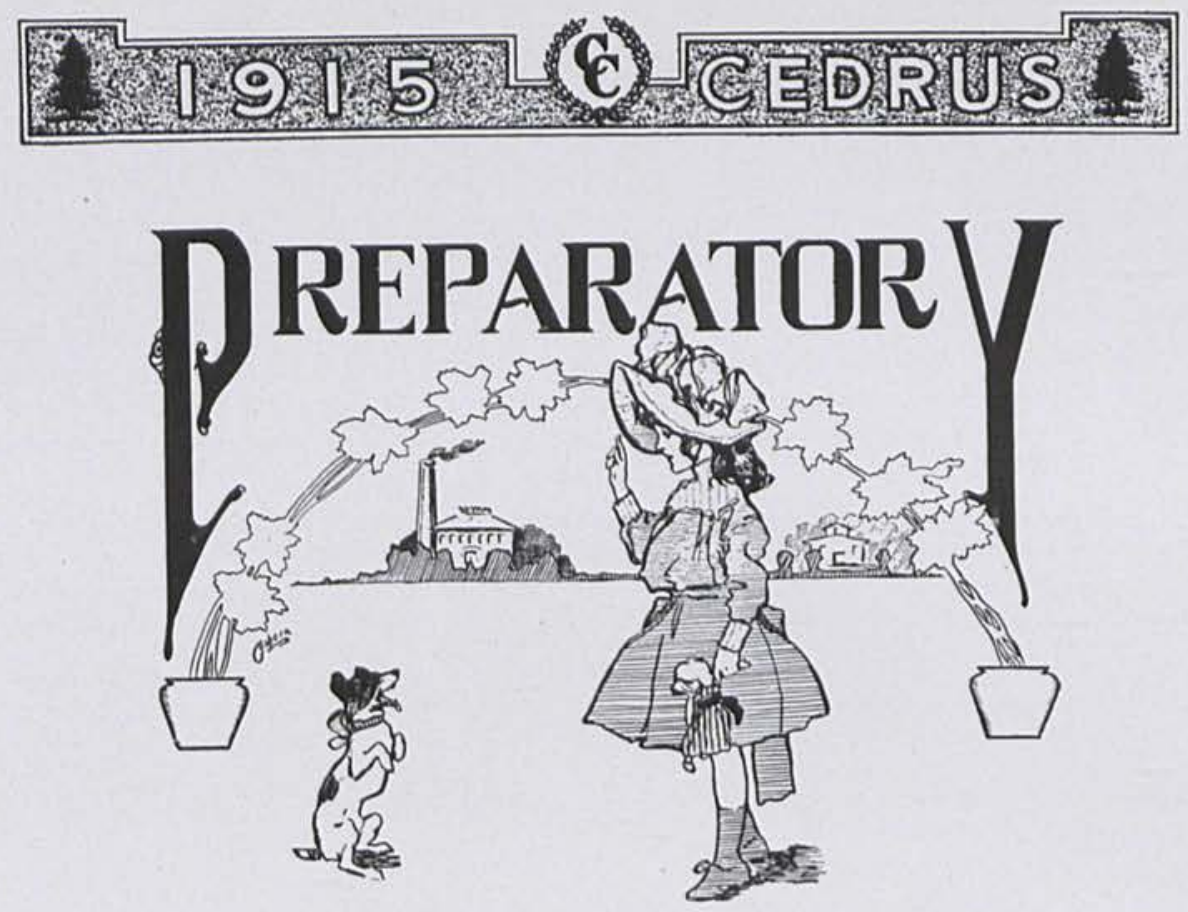

\section{"The Preps"}

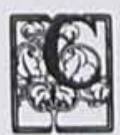

OLLEGE LIFE, to the outsider, seems much the same; but to the student five divisions are apparent. The first of these is the Seniors, who stroll about slowly and impressively. Everyone looks up (?) to them. Next comes the Juniors, who in former days were noted for their belligerency. The third is the "Sophs" and the fourth is those, who in their own language are called "Freshies," in ours "Blowhards." The Fifth is "nostra provincia" or the "preps." Our history though somewhat short at present, is, we believe, destined to be synonymous with that of the nation. We were at first, perhaps, timid and bashful, but we have proved to be veritable "diamonds in the rough." We were well instructed by the upper classmen whose advice we wisely neglected to follow. We have nearly everything except midnight botanizing parties of which we hear so much. The Juniors especially, are famous for their analysis of tulips and daisies. Though small in numbers we have great hopes, for "Great oaks from little acorns grow." Perhaps in comparison with former classes we are as yet not especially distinguished, but we believe with Shakespeare that:

"There is a tide in the affairs of men,

Which, taken at the flood, leads on to fortune,

Omitted, all the voyage of their life

Is bound in shallows and in miseries." 

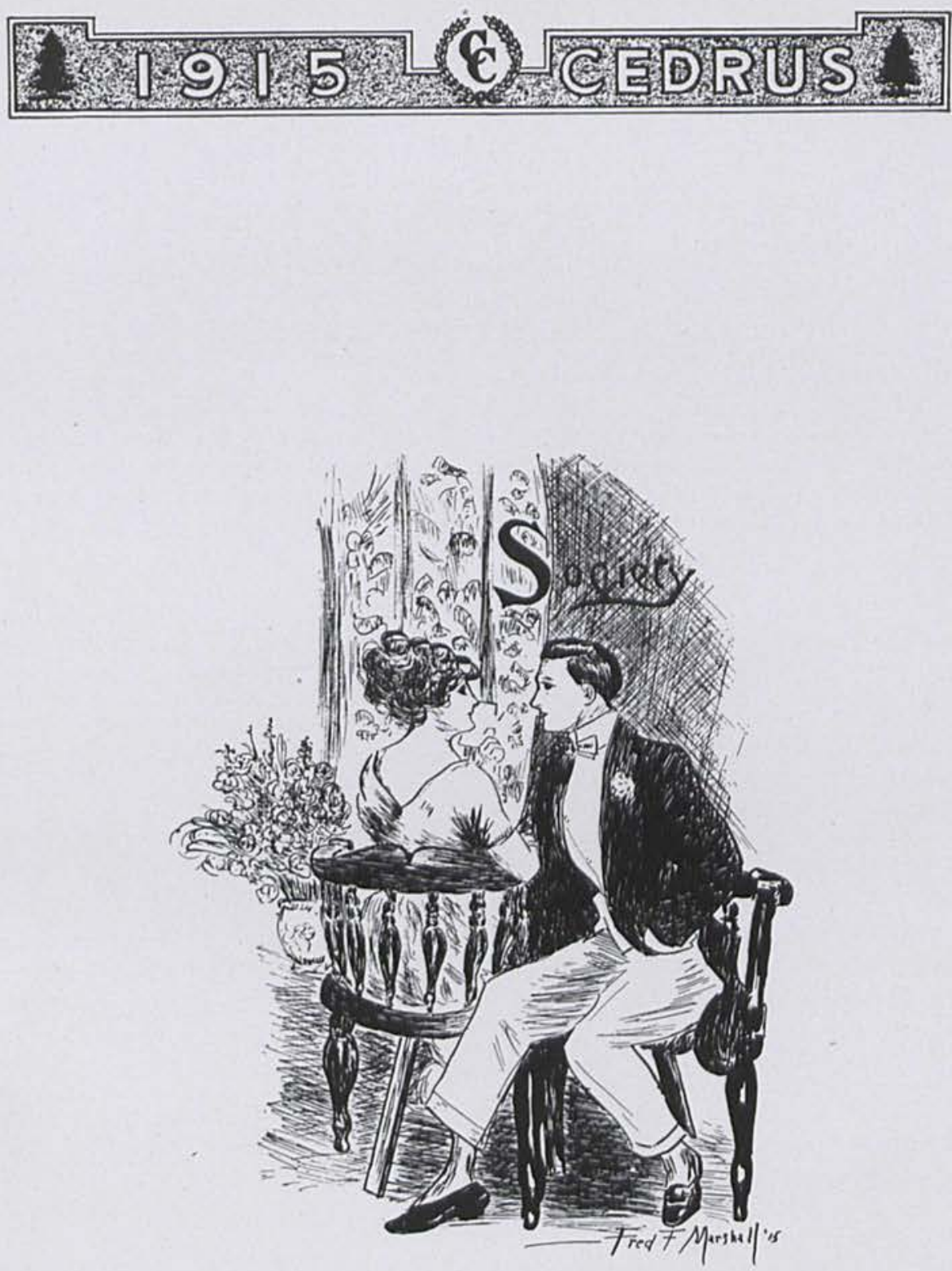


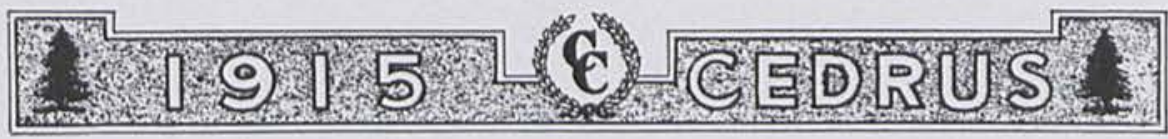

\section{Philosophic Reception}

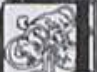

F THE events in Cedarville College life that are looked forward to by all old students, and ever remembered by newcomers, none perhaps are looked forward to more eagerly than the literary receptions at the beginning of the year. On September 18th, the Philosophic Literary Society held their annual reception in the Philosophic hall, which they had decorated for the occasion. The evening was spent in frolic and mirth until about ten o'clock, when the crowd was invited downstairs to partake of a sumptuous repast. Immediately afterward, the address of welcome was given by the President and toasts were responded to by representatives from the Philadelphian society and one from the faculty. Music for the evening was furnished by Miss Helen Oglesbee, '18, Miss Mary Hastings, '14, and Mr. Hugh Turnbull,'12.

\section{PHILADELPHIAN RECEPTION}

One week after the Philosophic reception, the Philadelphians royally entertained the Philosophics, alumni, faculty, and friends. There were about eighty present and the evening was spent in jollity and merriment. Everyone was made to feel welcome. At ten-thirty all were invited to the lower story, where a delightful luncheon was served. Toasts were responded to by a number of the faculty, each of whom tried to outdo the other in telling funny stories. Toasts were also responded to by representatives from the Philosophic society. At a late hour all departed, grateful to the Philo's for the entertainment of the evening.

\section{CHRISTIAN ENDEAVOR RECEPTION}

College people are all too much inclined to think that church socials are rather tame affairs, but the Reform Presbyterian Christian Endeavorers have proven that they are not necessarily of such a nature. The Christian Endeavor reception has come to be an annual affair. Weeks before school commences plans are made to welcome the new students and to hold a reception at the earliest date possible. That date this year was September 11. At seven o'clock the spacious church parlors were thrown open and were soon filled with a crowd of merry voung people. Games of a get-acquainted nature were played until nine-thirty. At that time all were invited to the basement to partake of the good things there provided. About eleven o'clock all departed with a feeling of gratitude and good will toward Christian Endeavor.

\section{PROFESSOR AND MRS. McCHESNEY ENTERTAIN}

One of the most enjoyable events of the season was the reception and supper given to the college students on the evening of November 10, by Professor and Mrs. McChesney. Their spacious home was thrown open and the students were made welcome. About seven-thirty the guests were invited to the dining rooms, and a delicious supper was served. Solomon (James Chesnut, Jr.) only, and his ten wives remained behind and ate their supper in the sitting room. After supper the students were entertained as only Mrs. McChesney would be capable of entertaining. At a late hour all departed grateful to Professor and Mrs. McChesney for their hospitality. 


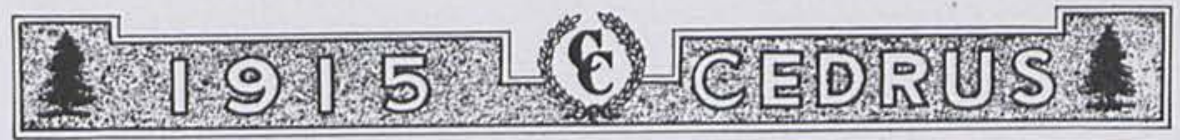

\section{HALLOWE'EN SOCIAL}

October 31, is a date looked forward to with eagerness and expectation by all students of C. C. This year it was the boys' turn to act as hosts and it is no idle boast to say that they eclipsed all previous Hallowe'en socials. The "Alford" was decorated to represent a moonlight scene in a cornfield. All the guests were requested to disguise themselves and the girls were shown the way to the gymnasium by means of a confetti trail. For about two hours there was much fun and mirth in trying to recognize each other. Finally the disguises were thrown off and the crowd seated. After this came a sumptuous chicken supper. Such a feed was never given before on a like occasion. Chicken, baked beans, pickles, buns, and coffee completed the menu. Orange-ade was served from an artificial spring in the center of the floor. Further entertainment was provided after supper and at a late hour the guests departed feeling that they had spent the most enjoyable evening of the season.

\section{FRESHMAN "PROM."}

Cedarville, Ohio, March 13, 1915

\section{My DeAR Old "Mutt":}

Say, old fellow, do you know, we're mighty fortunate that we're not Freshmen this year, and that you are equally as unfortunate that you could not be in on the Freshman spread given the twenty-sixth of January. You want to know how it happened, do you? Well, you see, it was this way. There are twenty-one Freshmen in school this year, and while they are without a doubt, made of good stuff, they, like all Freshmen, had to be taken down a step. They got the notion into their heads that they could just clean up the floor in a basket ball game with the Upper Classmen. The Upper Classmen challenged them to play and, Freshmanlike, without any deliberation they promptly accepted the challenge. January 12, was the date set for the contest, and as the time drew near, you can imagine the excitement. Everybody was out that night. and the Freshmen did valiantly, but the girls were sorely defeated. The boys however turned the tables on the Upper Classmen and won their game. I guess I forgot to tell you that when the challenge was made. the losers were to set up the "eats" to the winners. Well, when the points were added the Upper Classmen were found to be ahead, and it was up to the Freshmen to feed the rest of us. They were not the lads and lassies to back down, and on January 26, they gave us a B-I-G feed, now, I'll tell you they did. I can't remember just now what all we did have, but there were chicken "patties" and baked beans and pickles and salad and nabiscoes and gelatine and. - oh, I can't tell you what all, now,- - but I do remember that to finish up on we had some of Dr. Chesnut's funny stories. Oh, I'll tell you it was great. We'll never forget it, and I only wish you could have been here, it would have done your heart good as well as your stomach.

Well, as time and space are somewhat limited I will have to call a halt, so good-by.

$$
\text { Your old "pal," }
$$

"BENEDICT." 

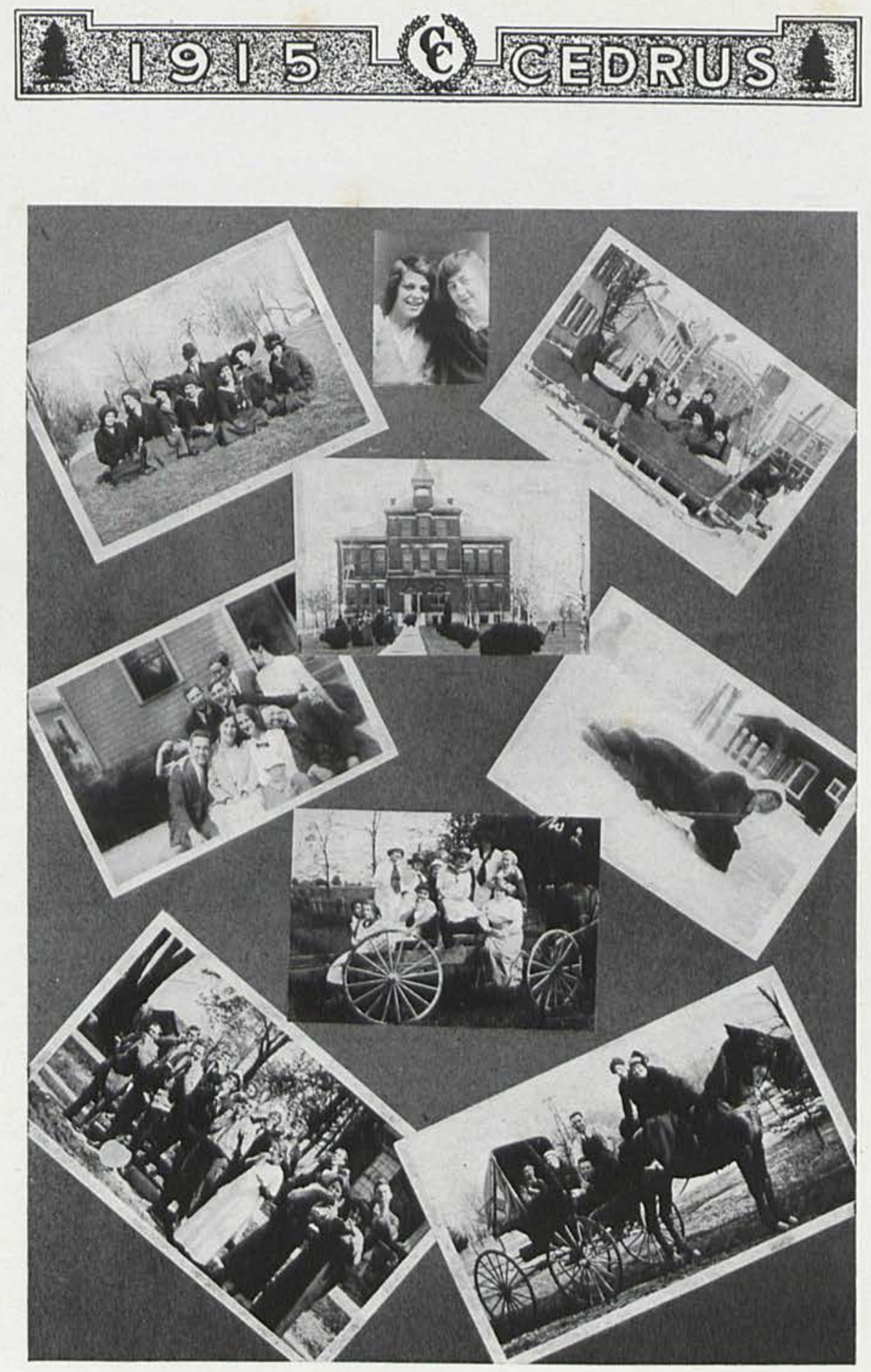

OUt For a Good Time 

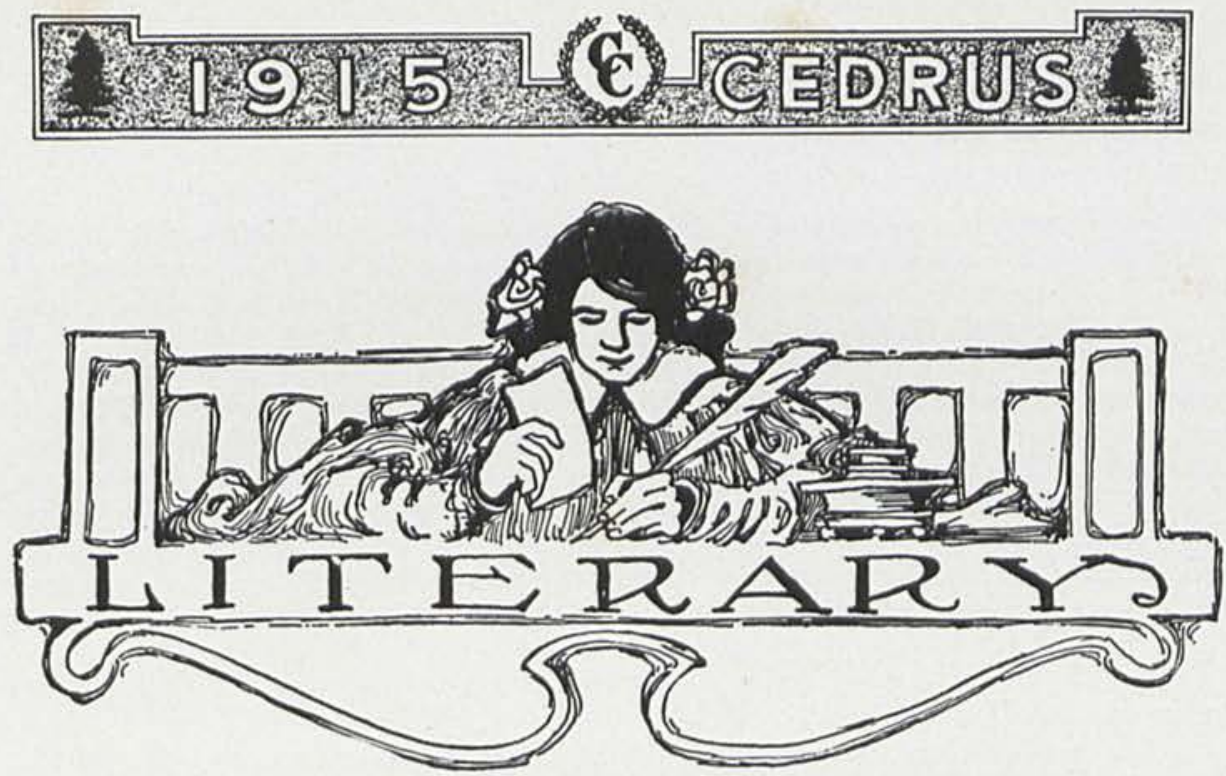

\section{The Match-making Mules}

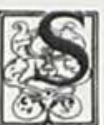

TANDING in the doorway of his favorite club, Richard Cozens Warrington was puzzled. Not that he would admit it. He was too proud to do that. But Dick wondered what it all could mean. Fresh from Harvard, Dick Warrington was as fine a specimen of the care-free youth as ever walked Broadway. He had been the leader of the most exclusive set at college, and now two weeks after his return to Cederton, he was the acknowledged leader of his club and the general favorite of society.

"Hello! Old scout! Why so glum? Cork up the sad stuff and let me treat you to a dose of billiards and good cheer." It was Arthur Denton, a chum of Dick's.

"Sorry Art, old top, but I must be going, I am busy to-night."

"Too bad! Hope the blues aren't fatal," responded Art cheerfully. Dick smiled as he slowly looked down at the note in his hand. Then placing the note in his pocket, he bade a hasty good-bye and departed.

Immaculate, Dick appeared to be a veritable prince of men as he descended the steps of his father's elegant mansion, and stepped into the tonneau of his long, gray, sixty horse-power car, the pride of his heart. He seemed to be in the surroundings where one would naturally expect to find him. Deftly he started the motor car and darted off towards the home of Dr. Brownlee, whose daughter Dorothy, was one of his life-long friends. It was only a few squares to the Brownlee home, so Dick drove slowly, meanwhile heaving a sigh of satisfaction and content with all the world. Life seemed sweet to Dick. Few of its troubles had ever crossed his path. Fate had been good to him: so he mused. Thus it was, that Dick was in a particularly amiable frame of mind as he ascended the steps of the Doctor's beautiful residence and pushed the bell.

He was cordially received by Mrs. Brownlee, who had always liked Dick's impulsiveness and warm-heartedness; and he greeted her with the boyish enthusiasm characteristic of him. They were conversing pleasantly when Dorothy entered the 


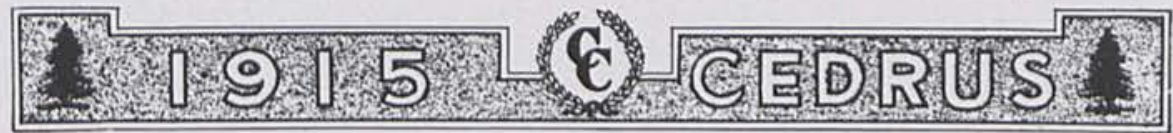

drawing-room. She had never seemed lovelier to Dick, and as he rose to meet her his eyes betokened the homage which beauty naturally wins. After a few moments of delightful conversation Mrs. Brownlee withdrew, leaving the two eagerly relating tales of their college life and singing favorite songs.

Later when Dick assayed to leave her, the beauty of the night made him feel that a few minutes in the car would be a fitting climax to the evening's delight. Dorothy readily acquiesced, and so in a few moments they were spinning along over the smooth pavements. The moon was shining brightly and filled the night with its radiance, transfiguring everything it touched. The spell of the night held them. Neither Dorothy nor Dick spoke. Silently they went, on and on, until the open country was reached. "Grand! isn't it?" said Dick, who was the first to break the silence.

"Lovely," breathed Dorothy.

"How fine it is to live," exclaimed Dick.

Dorothy's only answer was a low murmur of joy, as she turned her shining eyes to the eyes of Dick above.

On the following morning Dick Warrington presented himself at the office of Dr. Brownlee in answer to his brief note. As he entered the room, a vague, unreasonable fear seemed to creep over Dick for a moment, but only for a moment. He wondered what business Dr. Brownlee could have with him.

Just then the door of the inner office opened and with a word of greeting the Doctor ushered Dick into the room and requested him to be seated. For some unaccountable reason Dick preferred to stand. Dr. Brownlee said nothing. $\mathrm{He}$ was evidently waiting for Dick to begin. "I called this morning. Doctor Brownlee, in answer to your note of yesterday." Dr. Brownlee was silent. He seemed to be studying Dick intently. Slowly, he scrutinized him from head to foot and back again. Dick reddened. Dr. Brownlee seemed so serious. Dick shifted about uneasily and awkwardly pushed back his hair with his hand.

"Richard," the Doctor began, then stopped as suddenly as he had commenced, and paced nervously to and fro. Stopping opposite Dick, he again requested him to be seated, and feeling the utter uselessness of it, Dick sat down. "Dick," he said. and the familiar name from him was unusual, "I have known you all your life. I have always been interested in you. I have watched you at work and at play and I like you Dick, always did. It just came naturally. Then four years ago you went to college. There you learned many things and formed new acquaintances and developed new ideals. Now you have returned to us, and some of us are sorry that you went away. Dick, you aren't the boy you were four years ago and you're not the man I want my girl to marry."

Dick was stunned, for the idea that Dorothy should fail to be his had never entered his mind. With a dazed expression he looked up at the Doctor, but said not a word. The Doctor continued. "Dick, you are a drone and a parasite. What work do you propose to accomplish? The world demands results, not methods, and the young man of today must produce, not promise. Until he has made good, no young man shall win my daughter's hand. I trust that you understand. Good-by."

With mingled feelings, Dick walked out of the office, stumbling blindly down the stairs. "A drone and a parasite," he repeated. "Does the Doctor mean that I must toil like a slave and acquire an honest and frugal look? Am I, the son of James Warrington, to be subject to the rule of labor? Must I give up my free time, my sports and my friends to prove to Dr. Brownlee that I am worthy of Dorothy?"

Dick spent the next day at the club, where his gloom became so noticeable that he was chided by his companions. He struggled and struggled in a vain effort to 


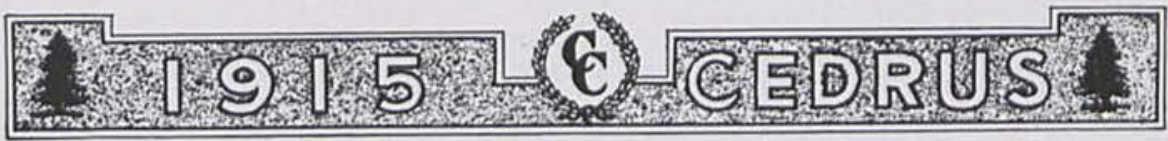

vindicate his life to himself in the light of Dr. Brownlee's charges. "Hang it, what's the matter anyway," inquired Art not unkindly. "You seem all broken up, old pal." Dick.

"Had a little hard luck the other day's all. I'll be over it in a day or two," said

Slowly the inevitable made its appeal to Dick, so swallowing his pride in the best manner possible, he finally determined to prove his worth to Dr. Brownlee. He was too proud to ask his father or his father's friends for work, so seeking a paper he searched the columns for situations which an inexperienced man could fill. This one he found:

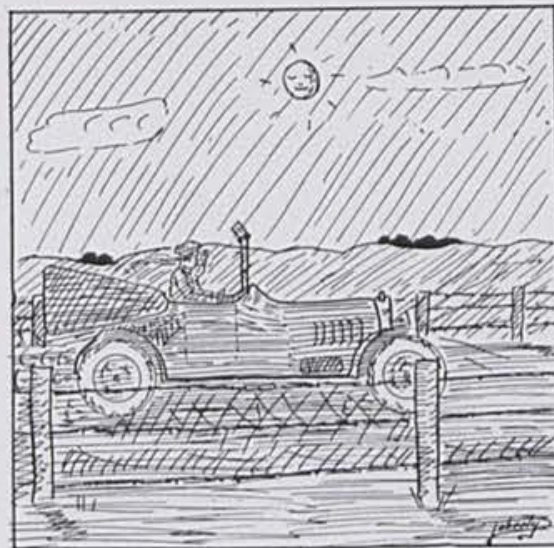
murmer of joy, as she raised her shining eyes to the eyes of Dick above."
Dorothy's only answer was a low

WANTED - Teamsters to haul gravel at $\$ 2.00$ per day. Teams supplied. Apply at office 807, Smith Bldg.

Dick had been hoping to find something good. His anticipation had been raised to a high pitch and it seemed cruel that it should be dealt such a blow. "I couldn't take a job like that of course. How would it look to see a millionaire's son hauling gravel!" $\mathrm{He}$ laughed bitterly at the thought. Then the night that he had taken Dorothy for the ride came to his mind and he remembered how happy he had been and how he had thought nothing could mar their happiness.

All at once it seemed that the Warrington in him spoke and immediately he turned his steps toward the office to which he was directed by the ad. He determined to apply for the job. The application was accepted and he was instructed to walk a mile out of the city to the gravel pit where further orders awaited him. Dick walked briskly along, at times gay and at times bitter as he thought of his new venture. But his resolutions never failed. When he found the boss, Dick was given his team, a pair of mules, small, indeed, when compared with the huge horses some of the other men were driving. "They're small, but they're all there when it comes to pulling," said the boss. "They can produce," thought Dick.

With surprisingly few instructions for one so ignorant of all kinds of work, Dick and his mules soon became known and respected among the men. Dick was easily able to hold his own in every experience. Thanks to his athletic habits, the soreness in his muscles disappeared after the first few days and Dick gained a faint sense of the satisfaction to be found in honest toil. As he worked with his little mules day after day, he was surprised at his admiration of the sturdy creatures, who were able and willing to do much more than their share of the work. The sun beat down fiercely on the men as they worked, and except for an occasional sentence the only sound was that of the thump, thump of the gravel as the wagons slowly filled.

By clever maneuvering and scheming Dick was able to keep his work secret from his friends. Art saw him several times and asked what he was doing, but Dick always put him off with an evasive answer. If he had only been able to see Dorothy a few times! But no! he would show Dr. Brownlee that a man can do what he wills. In the meantime he was miserable, and it had been only two weeks since his interview with the Doctor. 


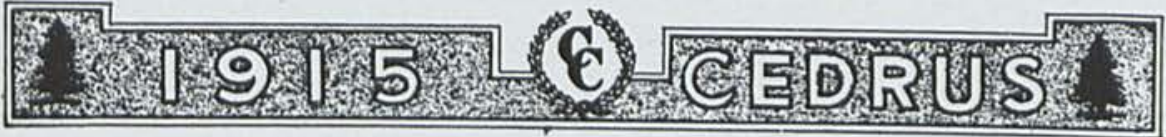

As Dick was returning to the pit one hot July afternoon, he stopped at the entrance to get a greatly desired drink of fresh water. While there he noticed a familiar-looking automobile approaching along the road that ran north of the pit. He soon recognized it as Dr. Brownlee's and wondered what business could bring him there. When the machine got almost opposite Dick, it suddenly dropped into a mud-hole left by a recent rain. Vainly the machine tried to proceed on its way, but it was soon evident that help from some other source would be necessary.

"The mules! Just the thing," thought Dick. "They will pull him out in a hurry." Hastening toward the scene of the mishap, Dick offered to assist and his offer was immediately accepted. In a short time the automobile was on solid ground once more. Dick unhitched the mules from the car and then the Doctor while thanking him for his assistance recognized him in spite of his overalls and his red bandana.

"Well! Well! A gravel pit's the last place I would expect to find James Warrington's son!" exclaimed the Doctor.

"Doctor Brownlee, I have accepted your terms and am now preparing myself for civil engineering and construction work by beginning at the bottom and learning to appreciate the attitude of the common laborer. These hardy little mules have taught me a lesson. I have determined that I shall succeed in my profession." Dick spoke with a new note of manliness in his voice and manner.

"And succeed you will, as you well deserve," responded the Doctor heartily. "There is someone in the car whom you would perhaps like to see." Dick turned to the side of the machine and the joy in Dorothy's eyes and the greeting upon her lips was an ample reward for those awful days of torture. Dorothy had heard what Dick had told her father and she understood perfectly.

"I shall return to work tomorrow morning," said Dick.

"Oh Dick! how much we owe to those dear little mules."

$$
\text { "Rondo Villmell, '16" }
$$

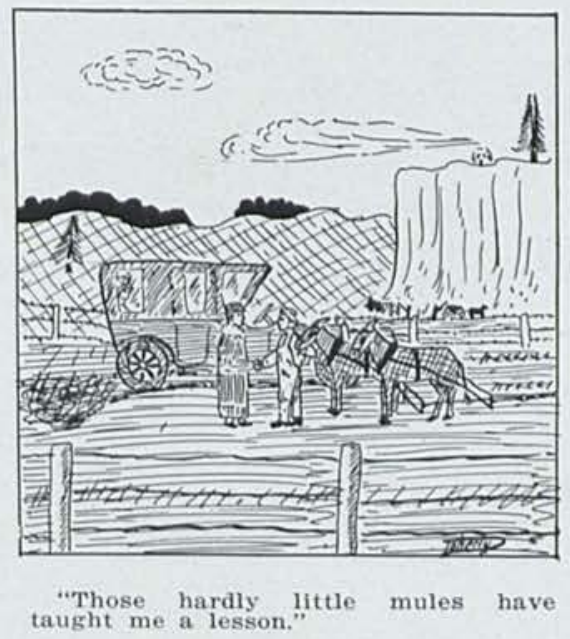




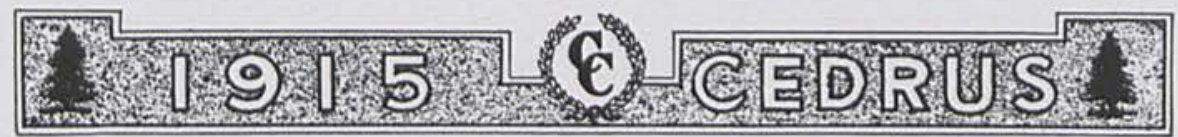

Events of Interest

\section{CEDAR DAY}

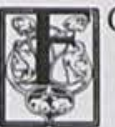

OUR YEARS ago the faculty decided to set apart a special day, in the spring of the year, when the community and the college could join in a good time. The first attempt was so successful that the observance of "Cedar Day" is now an established custom. It is a day when the classes each perform some stunt for the amusement of spectators. The people of the community are invited to attend and are thus brought into closer touch with the college, and are given more of an insight into our work. Last "Cedar Day," in spite of the fact that it was a disagreeable day, over three hundred were present. A sumptuous dinner was served in the gymnasium. After dinner Mr. Cameron Ross gave the "Cedar Day" oration and speeches were made by representative citizens of the community. In this way "Cedar Day" has become the means of greatly strengthening the bond of friendship between the college and the community.

\section{ORATORICAL ASSOCIATION}

For several years Cedarville College has been a member of the Intercollegiate Oratorical Association and has always been represented in the Intercollegiate Contest. We have always taken a lively interest in oratory and this year there were six in the preliminary contest. Mr. Cameron McClure was the winner and ably represented Cedarville in the Intercollegiate Contest at Wittenberg College, Springfield, Ohio.

\section{THE BIBLE READING CONTEST}

Dr. C. M. Ritchie, Pastor of the United Presbyterian church, Clifton, Ohio, has offered prizes of three, five, and seven dollars respectively for a Bible Reading Contest. Any chapter of the Bible may be read. Usually a good deal of interest is taken in the contest. Last year fifteen participated; and, as Dr. Ritchie said, there were some in the audience who heard more of the Bible that night than they had heard or read in a year. This year the contest will be held in April, and sixteen will take part. We wish in this public way to thank Dr. Ritchie for the interest he has always manifested in our college, and also for his generous prizes.

\section{SENIOR PLAY}

One of the strongest attractions of Commencement week is the Class night play given by the Seniors. Several times one of Shakespeare's plays has been given with a good degree of success. The play last spring was not a production of Shakespeare's, but a comedy entitled "The College Town." The cast of characters consisted of twenty-four persons. The play was well given and was presented before a large audience. 


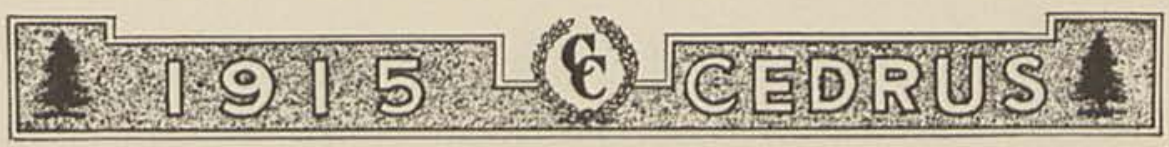

\section{Cedarville's Representatives On Foreign Mission Fields}
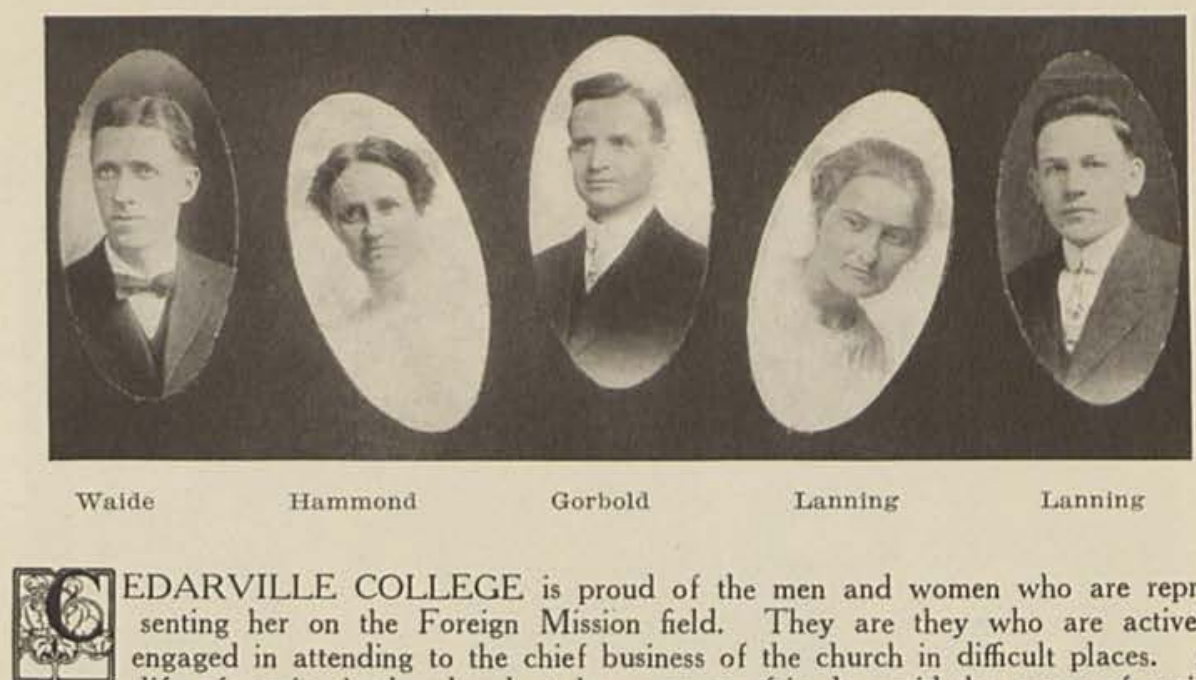

EDARVILLE COLLEGE is proud of the men and women who are representing her on the Foreign Mission field. They are they who are actively engaged in attending to the chief business of the church in difficult places. A life of service in the church at home among friends, amid the scenes of native land is, indeed, commendable; but to go to a strange land and labor among an unfamiliar people requires grace, faith, and courage. Let honor be given to whom honor is due.

Rev. Raymond Porter Gorbold, D.D., graduated from Cedarville College in 1897, and from Lane Theological Seminary in 1902. In 1903, he went to Japan under the auspices of the Presbyterian church. Dr. Wilbur Chapman, the great evangelist, says "Gorbold is the coming man in Japan." We predict that his name will go down in history with those of Livingstone and Paton.

Miss Alfaretta Hammond graduated in the class of 1903. She was appointed as a missionary to Egypt under the direction of the United Presbyterian church in 1904. She was home on a furlough in 1911, and received the Master's degree from her Alma Mater. She is now located in Beni Suef, Egypt, at the head of a large school for girls.

Rev. William Waide was an honor member of the class of 1909. His theological training was obtained at McCormick Seminary, Chicago, where he graduated in 1912. In the fall of that year he went to India under appointment from the Reformed Presbyterian church, where in conjunction with Dr. John C. Taylor, he has full supervision of the work of that denomination.

Miss Wilhelmina Edith Mitray-Lanning graduated in 1912. In the spring of 1914, she was united in marriage to Professor Roy A. Lanning, who for four years had been the efficient head of the science department of Cedarville College. In the fall of the same year under appointment by the Presbyterian church. Professor and Mrs. Lanning went to Teng-Chow Fu, Shantung province, North China.

The Foreign Mission Board of the Reformed Presbyterian Church can use more men and women. Who will offer their services? 

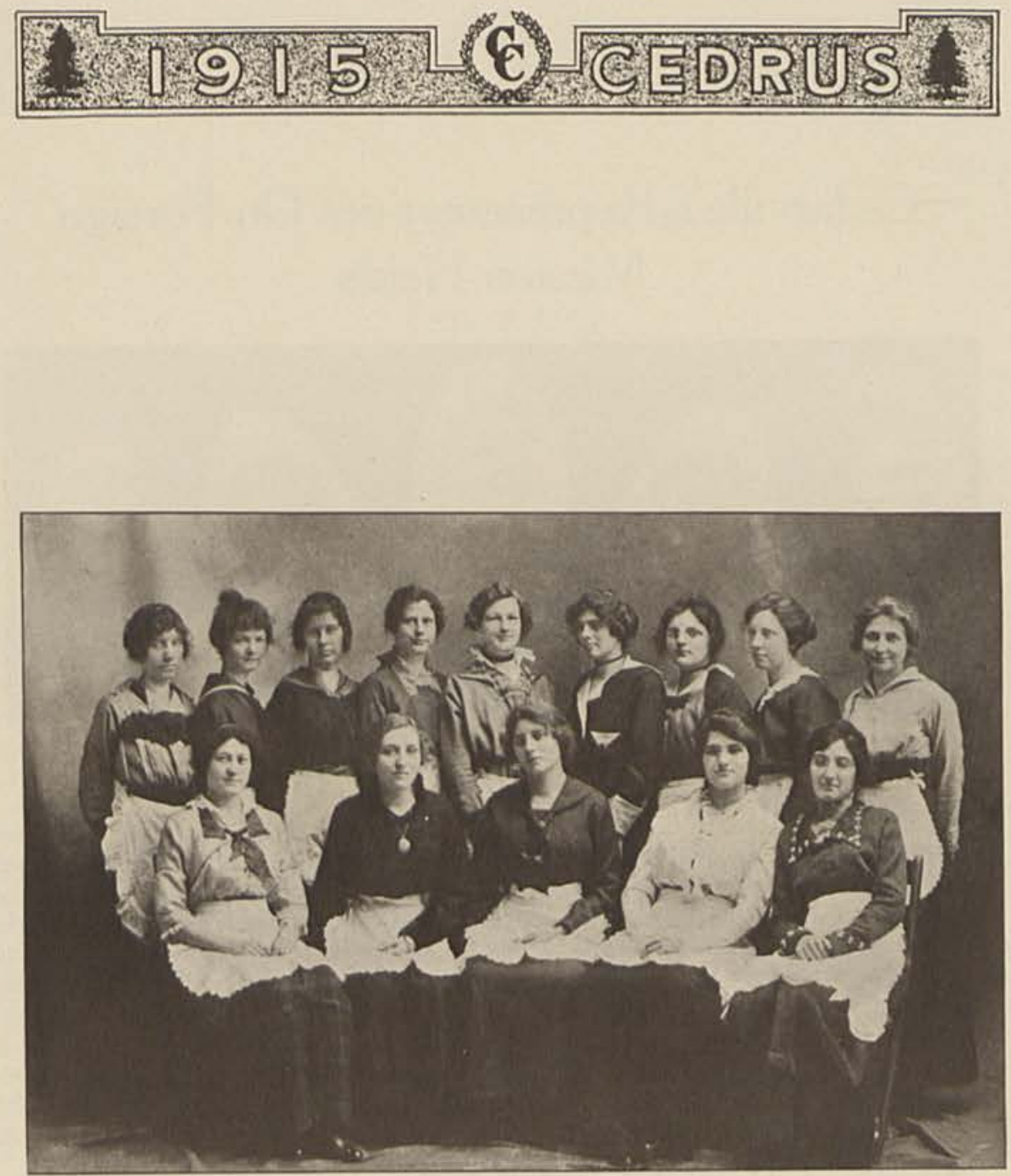

DOMESTIC SCIENCE STUDENTS

Standing: Townsley, Holliday, Tarbox, Murdock, McMillan, Burns, Collins, Dean, Baumgardner. Sirtinc: Boyd, Grindle, Little, Creswell, Bradfute. 


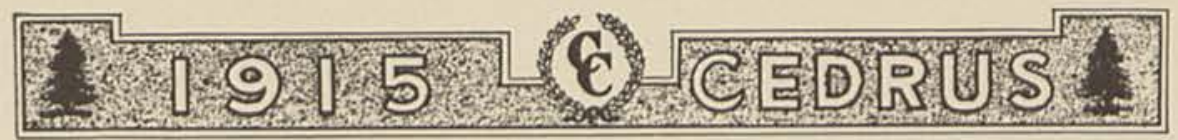

\section{The Domestic Science Class}

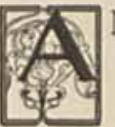

NYONE paying a visit to the basement rooms of the library on any Tuesday afternoon between the hours of three-thirty and five-thirty would find the less vacillating members of the above-pictured Domestic Science class more or less absorbed in the construction of garments in various stages of completion.

There on the left hand side as one enters the room is Eva Townsley, carefully measuring plaits with unrelenting accuracy. Near her is Ellen Tarbox, just finishing an apron so that she may learn to ply the shuttle. Donna Burns, with thread stretched taut between the forefinger and the thumb, and with the shuttle poised at an angle of forty-five degrees, is about to make the fatal thrust. One can hear her mutter, "Is it above or below this time?" On around the irregular circle formed about the sewing table is a chain of busy girls: Cornelia Bradfute, comparing seam with seam; Hattie Turner, bending her head intently over a slowly growing structure; Bertha Dean, passing the time on some entirely hand-made French lingerie; and Pauline Grindle, laboring with some troublesome French knots-for one finds a smack of Paris whereever garments are made. Marie Little and Blanche Baumgardner, the inseparable, are decorating some laundry bags with the branching featherstitch; and Eula Creswel! is matching colors and plaids, and planning the right combination of shades to harmonize best with the front of that dress. The circle is closed by Mabel Murdock, who is manipulating a crochet hook, and thus creating an intricate design for a dainty lace edge.

Out in the other room Ethel Boyd has the at first almost unrecognizable pieces of a pattern, neatly pinned to a long strip of goods, laid on the operating table. Across from her. Ethel McMillam is similarly employed; while at the other end of the table Dorothy Collins has applied the blade and has left great yawning openings, surrounded by a mere outline of material to show where the pattern formerly lay.

From one busy girl to another flits a figure, pulling wrinkles straight here, suggesting a slight change there, picking up a dropped stitch, putting the mark of approval on some dainty workmanship by a "That's fine, now for something else," or suggesting another trial to insure more nearly perfect results.

At five twenty-five there is a scurry for wraps, a gathering of needles, measuringtapes, scraps of goods and patterns-a flick of the light-and darkness settles down, and stillness, even more marked because of the busy chatter which had just been filling the room; for in a sewing class one can have the pleasantest sort of a time talking over current events and local happenings. 

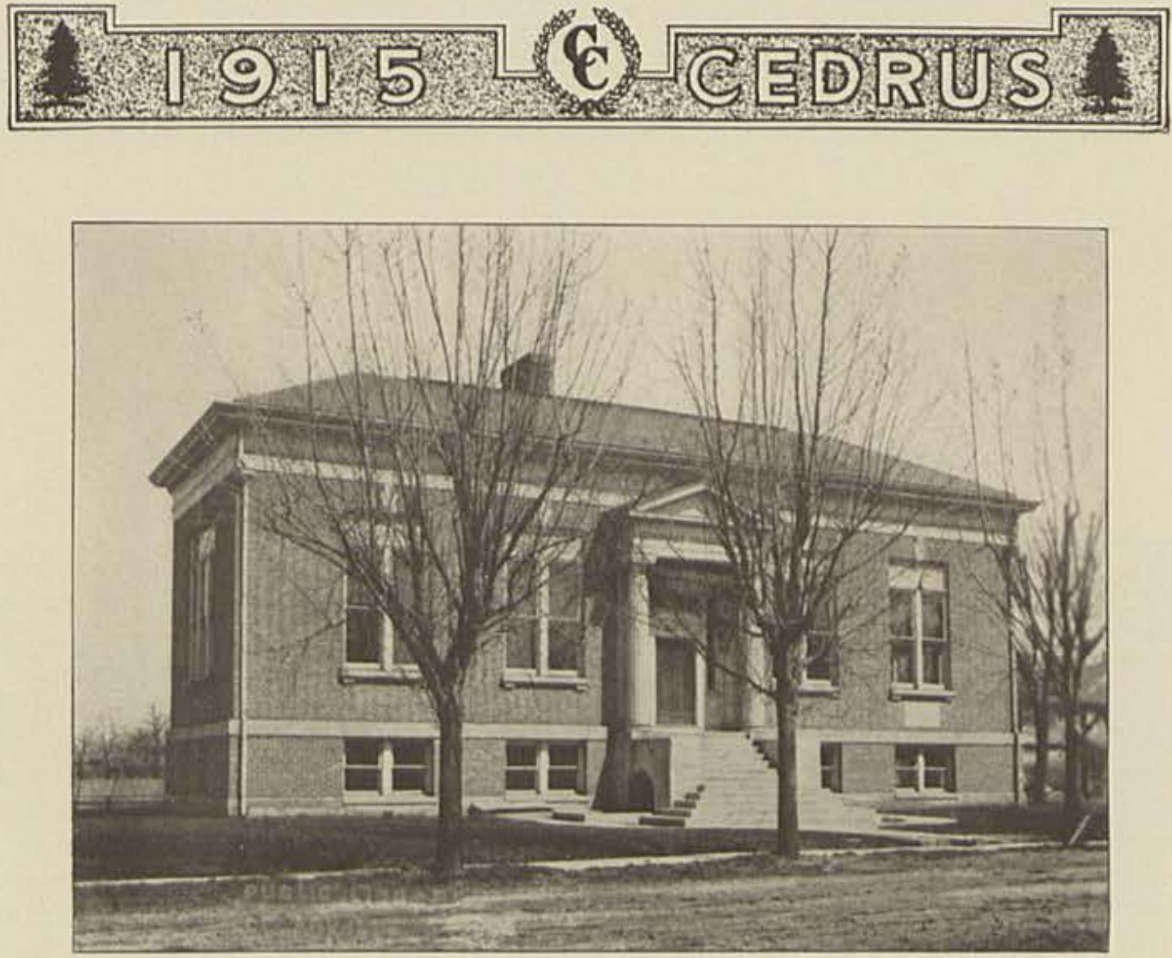

\section{The Library}

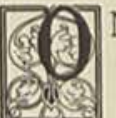

NE OF the greatest assets of any college is its library. This fact was early realized by the faculty of Cedarville College and in the fall of 1895, Dr. McChesney made an appeal to the congregations of the Reformed Presbyterian church for contributions to a library. In answer to this appeal over twelve hundred volumes were donated, and a number of the leading periodicals and magazines were provided for the reading tables. For a number of years the present chemistry recitation room was used for a library and managed jointly by faculty and students.

Such an arrangement only partially met the needs of the students. During the holiday season of 1905, through the efforts of Dr. David McKinney and Hon. Withelaw Reid, Andrew Carnegie offered Cedarville College a gift equal to the sum it could raise for an endowment. Twelve thousand dollars were secured within one year, and the present building was completed in the fall of 1908. Arrangements were made with the township for a union library, and about five thousand volumes are now found on its shelves, while many of the leading periodicals and magazines are found on its reading tables. The shelves will hold seventeen thousand volumes, and books are being added every year.

Space forbids telling of the activities in the library: for, besides the reading rooms, there are reception rooms, domestic science rooms, a physics laboratory, a seminary room and library, an office, and the President's room. It has meant and does mean a great deal to the students as well as to the outside patrons, and its outlook is very encouraging. 

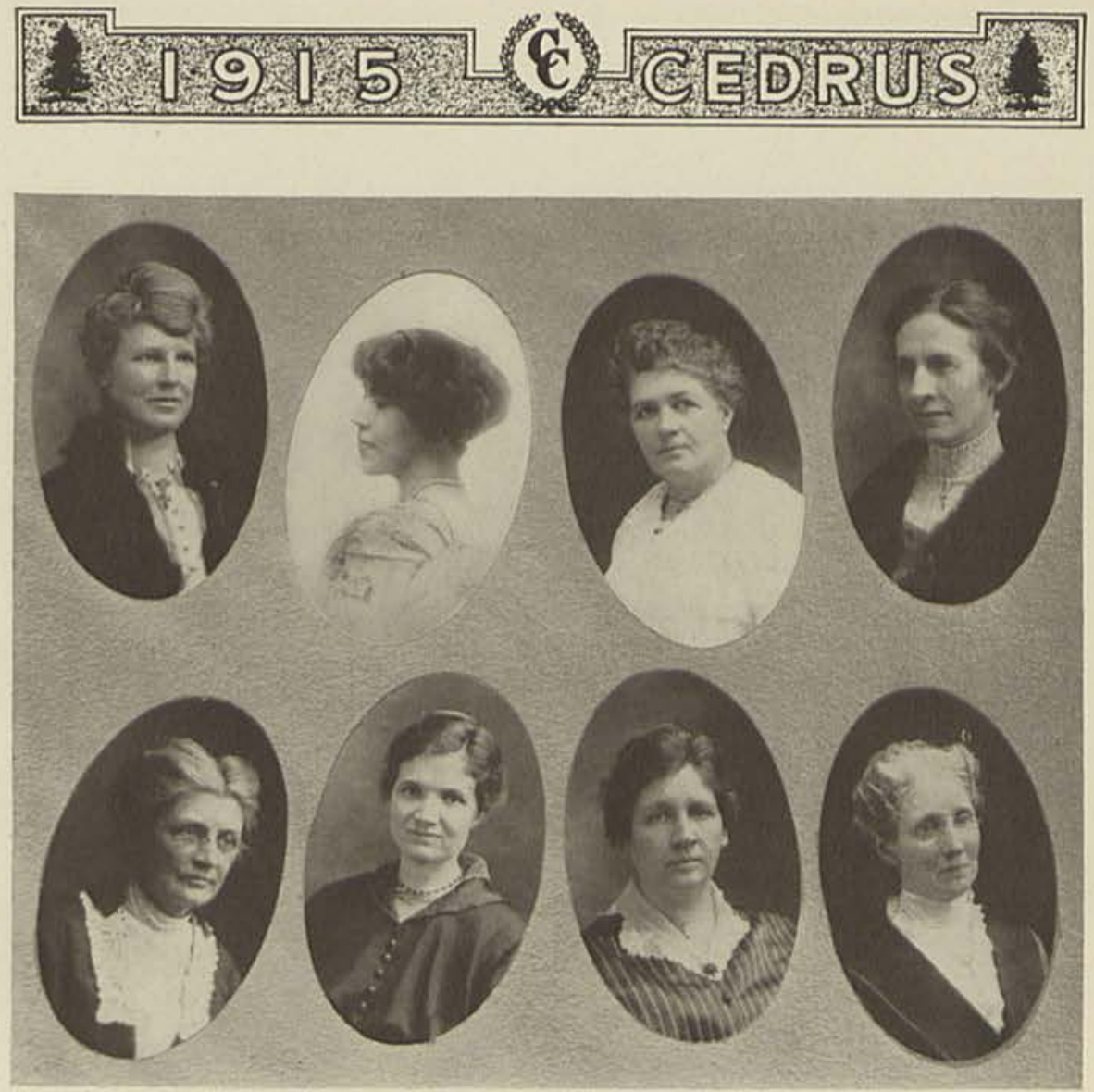

\section{The Ladies' Advisory Board}

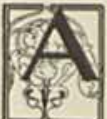

BOUT five years ago it was thought best for the welfare of Cedarville College that it should have a Ladies' Advisory Board. Consequently, ten ladies, representing the four different denominations of the village, were chosen. Mrs. W. E. Putt and Mrs. M. J. Taylor moving away left eight members on the board.

For a while the board seemed to lie dormant to its responsibilities, but finally awakened and decided to be of some use to the College.

First, the building was looked over and some necessary improvements were advised, which were carried out satisfactorily by the Trustees and the ladies were inspired to greater efforts. They decided to refurnish the girls' rest room, which they found needed some attention.

Their first venture was an oyster supper which was well patronized by the friends of the College, and from which they realized a neat sum. This assured the ladies that they could go ahead, since they found out that they could make money. The end of the year found the girls' room completely made over, with dainty new curtains, a beautiful new rug, and newly varnished floors.

This year the boys' rest room and the music room have been furnished in the same way. The ladies have many plans for similar improvements in other rooms, and for many other things; such as new lights, chairs, etc., which will be carried out soon. The Ladies' Board has become all that its name implies and more, and hopes to prove itself loyal and helpful to Cedarville College. 

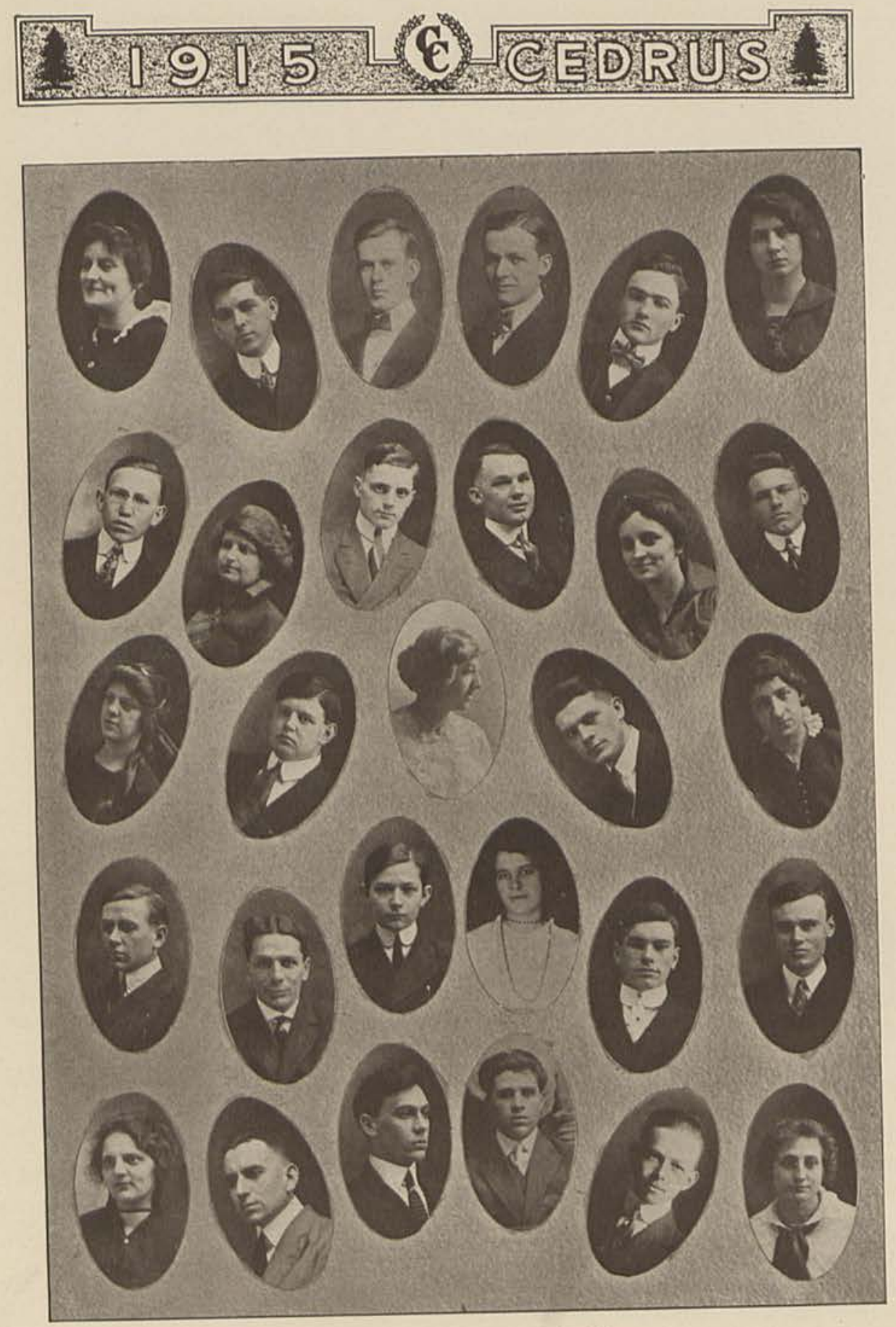

PHILADELPHIAN SOCIETY

Collins, Elder, Burns, Ritchie, Hutchinson, Little

McMillan Bird, Collins, McCorkell, Mendenhall, Collins

Shiplett, Bradfute, Oglesbee, Rife, Spencer

Short, Kennon, Ritchie, Hoskinson, McClure, Duff

Collins, Ross, Doherty, Hoskinson, Ritchie, Baumgardiner. 

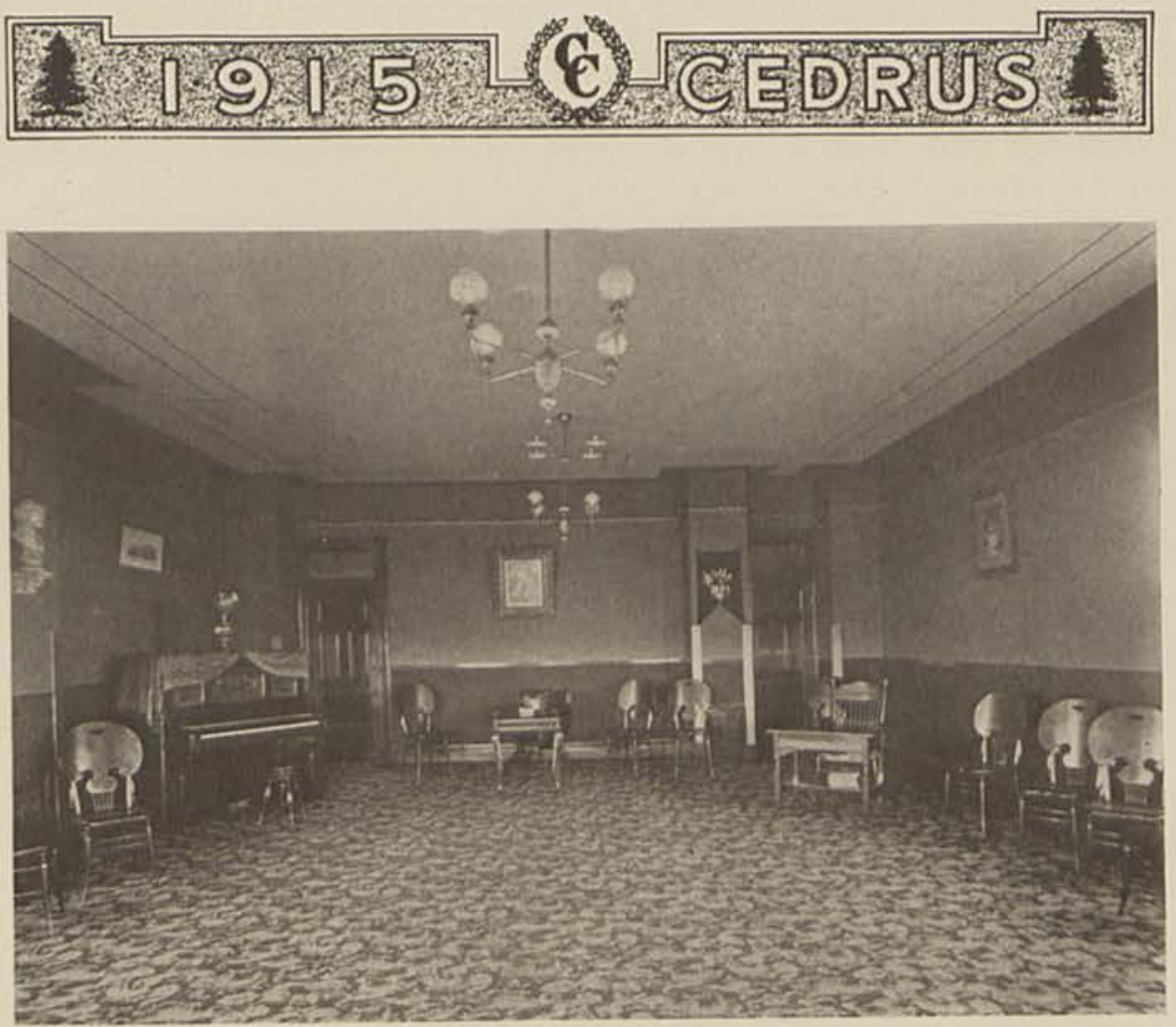

\section{Philadelphian Society}

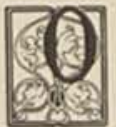

NE SUNNY afternoon twenty years ago last September, a band of enthusiastic students gathered on the college campus to consider the possibility of organizing a literary society. Only a few days after this the Philadelphian literary society, "with malice toward none and charity for all," flung to the breeze its pennant of Black and Cold. As the breezes wafted gently heavenward from the college spires, the little band of literary workers breathed this prayer, "May our colors ever be turned heavenward." The Black and Gold soon won favor among the students. The society grew in membership and enthusiasm. Finally, to facilitate matters, another society was organized, which indeed has ever striven to unfurl its colors in as lofty a breeze as has dear old Philo.

So much for "the dear dead days beyond recall." Just how is Philo acting in the living present? For the past two years the society has been governed by a new constitution. The members of the sociely are responsible for a certain number and variety of productions to be assigned by a program commiltee. A heavy fine and a sentence requiring the delinquent to give two productions of equal rank with the neglected performance, before the faculty, acts as a stimulus to more prompt and efficient work.

The meetings of this present school year have been unusually interesting and encouraging. The productions show careful preparation as well as talent on the part of the members.

Cedarville's representative at the Intercollegiale Oratorical contest last year came from the Philadelphian society; and in the preliminary contest this year every contestant wore the Black and Gold. Again, within the last year the society won merit for its college when one of the Philadelphians won a prize in the Perry Centennial essay contest. Lest we laud our beloved society too much and weary you, perhaps iwould be wise to leave a few things unsaid. So with one further word we close; to the friends of the college especially to the alumni, the sociely extends a welcome to its literary meet ings. Our latch string is out. 

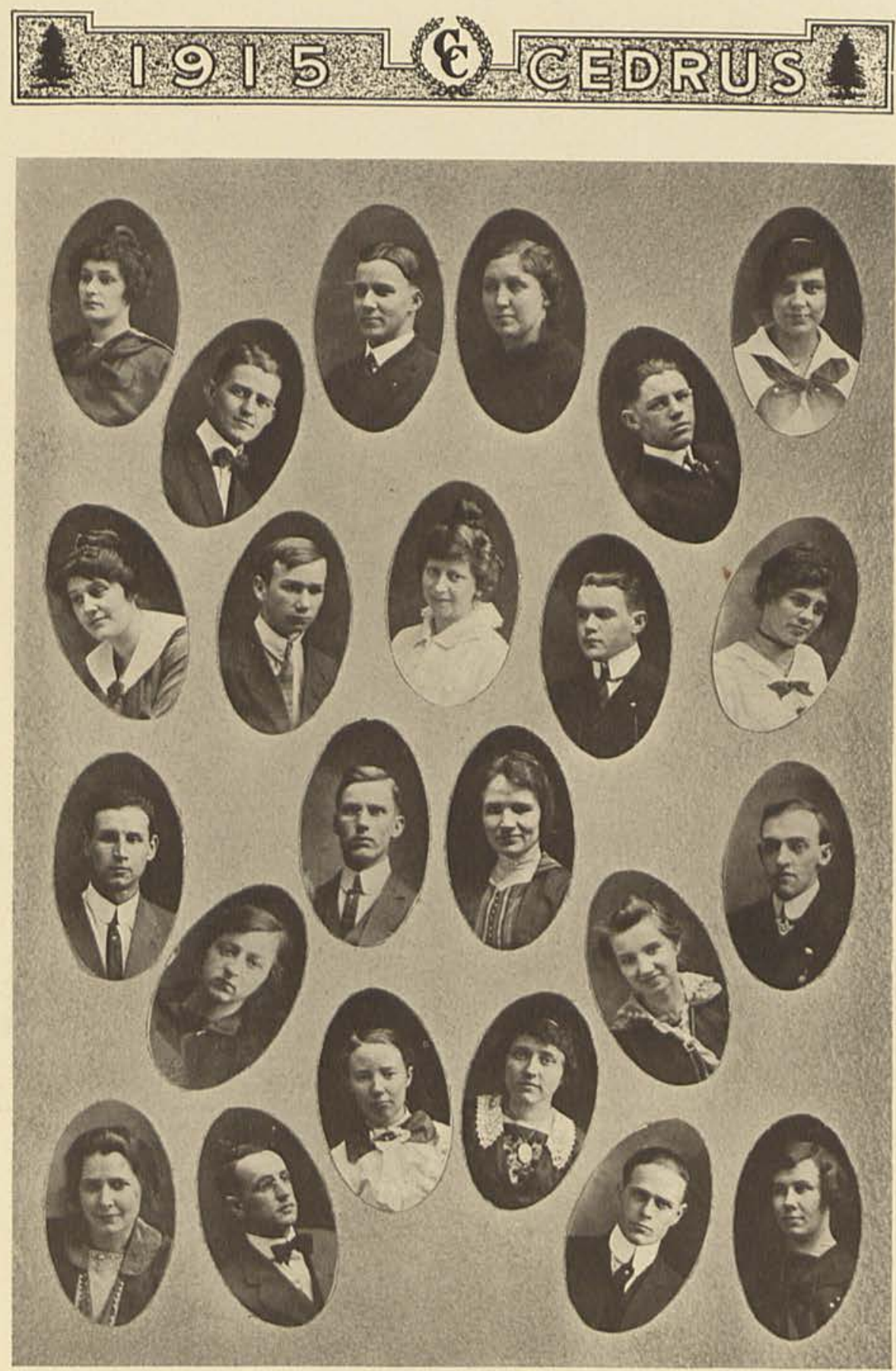

PHILOSOPHIC SOCIETY

Harris, Sterrett, Weaver, Somers, Barber, Wright

Corry, Boase, Wallace, Chesnut, Burns

Loyd, Clark, Creswell, Hastings

Graham, McCampbell, Gardner, Northup

Ramsey, Bird, Ramsey, Stormont 

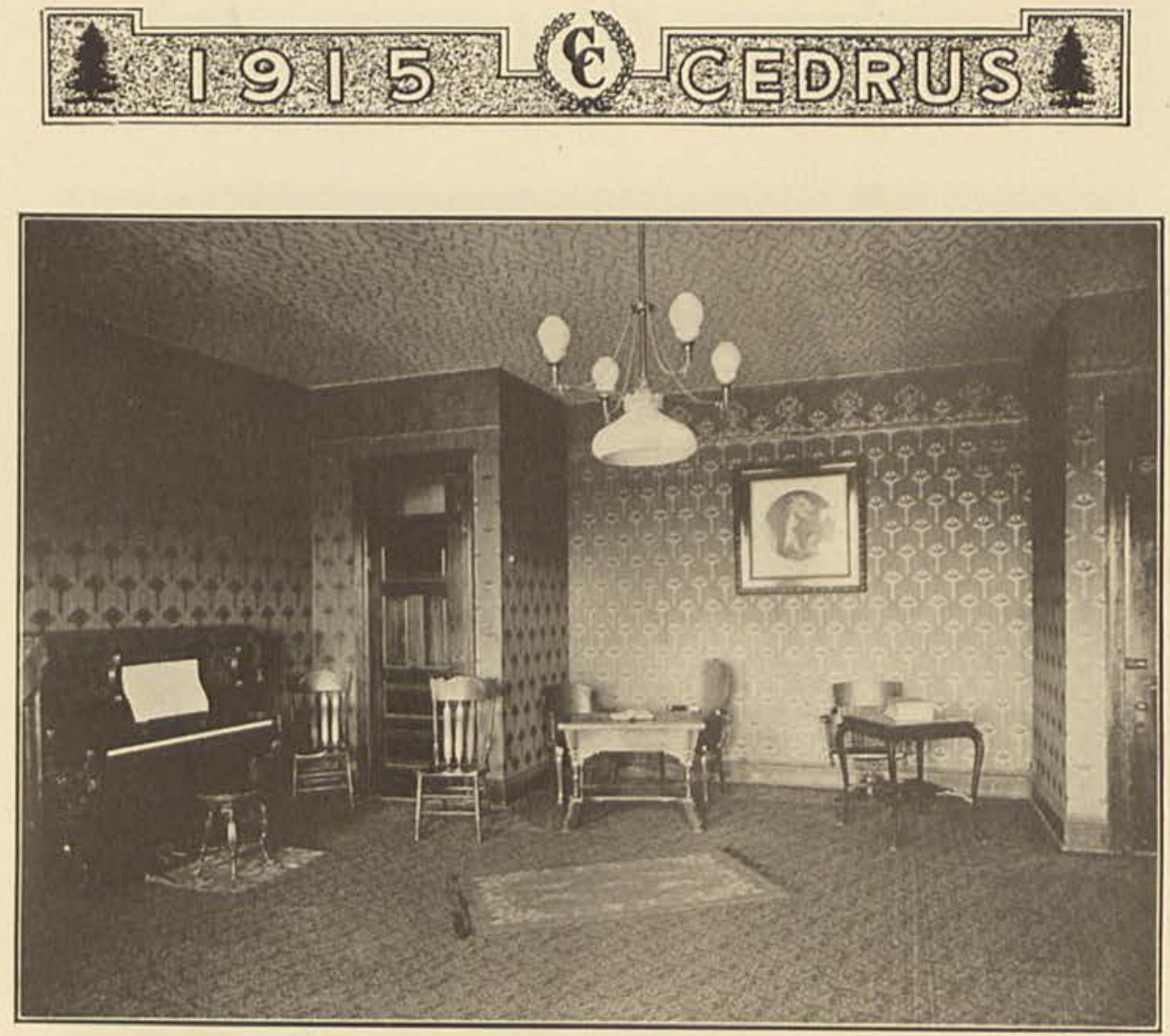

\section{Philosophic Society}

One year after the founding of Cedarville College, came the organization of the Philosophic Literary Society. Scarcely was it so momentous as the establishment of the college itself, yet it has been an important factor in the growth and development of the institution. If you are visiting the main building do not forget to explore our pleasant hall on the third floor. While you will find no elevator running to that story, we feel that you will be more than paid for the difficult task of climbing three flights of stairs. The colors green and white, are tastefully carried out in the furnishings. Recently it has been repapered, and new curtains sofien, and add much to the appearance of the room. From the windows one may look out over the campus, dolted here and there with the famous "three hundred trees."

Near the beginning of the year the annual reception was held in honor of the new students. The early part of the evening was given to music and games. We are glad to have had our ranks strengthened by such a goodly number of new members this year. Their work has been of a pleasing character, due perhaps to the "ambrosia" so kindly tendered them on the evening of their initiation. The work of the entire society has been progressing nicely and we have kept ever before us our motto, "Let it be perpetual." To the members and to all we give you greetings.

Noble Seniors, how it grieves us, That your days with us are o'er.

And may truth and duty guide you

As you sail out from this shore.

To the Juniors, we entreat you,

That the places left so bare.

By our Bird and Lloyd and Sterrett,

You will fill with genius rare.
Happy Sophomores, as you enter

Next into the Junior file;

You have work that you must conquer With that ever-present smile.

Faithful Freshmen, numb'ring seven, Earth's sufficiency you reach.

As the Sophomores taught you this year, Next year's Freshmen you can teach. 

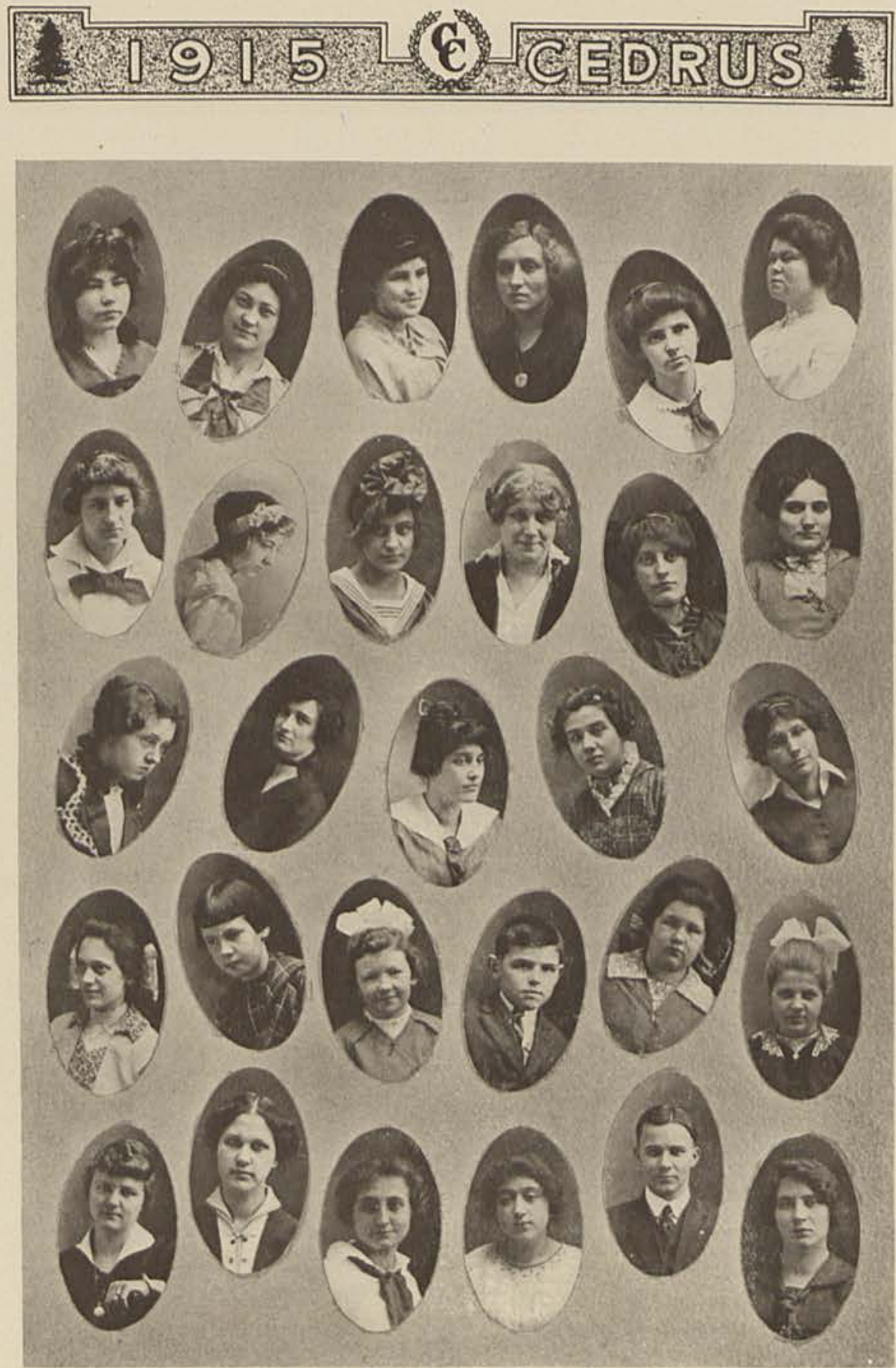

MUSIC STUDENTS

Post, Boyd, Blair, Grindle, Allen, Creswell

Spencer, Oglesbee, Wright, Crouse, Townsley, Conner

Andrews, McGiven, Corry, St. John, Cooley

Trumbo, Johnson, Iliffe, Little, Johnson, Oglesbee

Paine, Smith, Baumgardiner, Hammond, Weaver, Little 


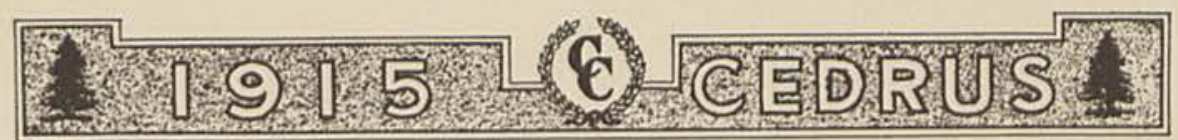

\section{Music Recital}

\section{PROGRAMME}

Impromptu

MisS MiLdRED Trumbo

Rhemhold

Polka de Concert

MisS INEZ CONNER

Barrelt

Bolero Lack

MisS WILMAH SPENCER

Processional March Ringuit

Mesdames Charles Payne and Leroy A.LLEN

Habanera from "Carmen"

Miss Gladys Post

Rhapsodie Hongroise No. 2.

Miss Helen Oglesbee

Last Idea Von Weber

Cramer

Miss Helen Creswell

The Royal Trumpeters

Brown

Misses Mildred Corry and Marie LitTle

Moonlight on the Lake

Miss MildRed Crouse

In the Woodland Living

Miss EleANORE JOHNSON

Fearis

Kragman

Polka Militare

Misses Ethel Boyd and Myrtle St. John

Assyrian March

Miss Pauline Grindle

Rustling Leaves

$$
\text { Miss Sarah SMITH }
$$

Spring Song

MISS IRENE WRIGHT

Engelman Wachs Hewiti Mendelssohn

Sechs Variationem

Miss Dorothy OGLesbeE

Robin's Return Miss LUCILE JOHNSON

Waltz from "Faust"

Misses Oglesbee, Creswell, and Trumbo

Dance of the Haymakers

MisS MILDRED CORRY

Polacca Brilliant

Mrs. Charles Payne

The Maid from the Highlands

Miss ETHEL Boyd

Sylphiden

$$
\text { Misses Inez Conner and Gladys Post }
$$

Beethoven Fischer Gounod Wilson Bohm Lange Franle 

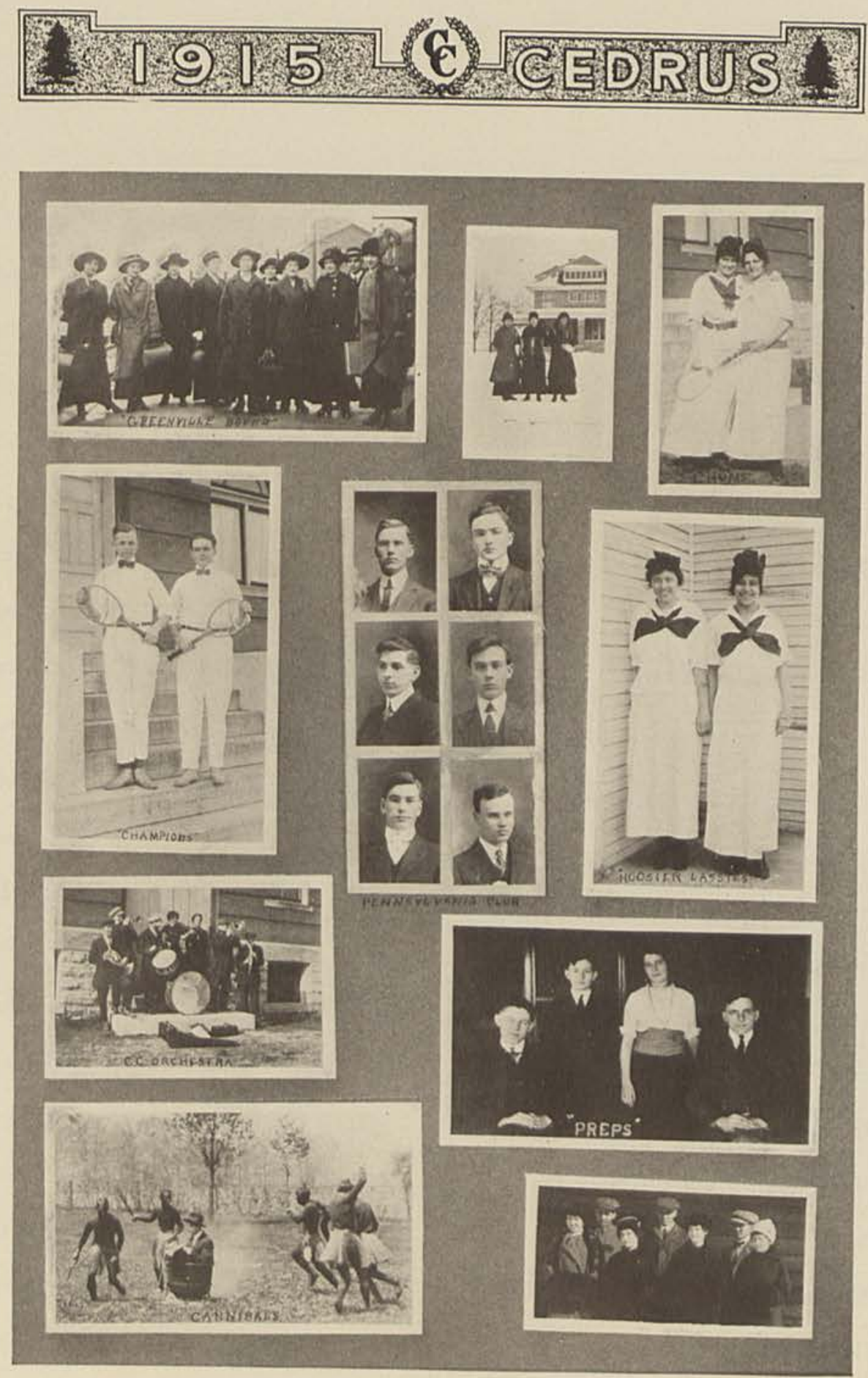

C. C. MERRY-MAKERS 

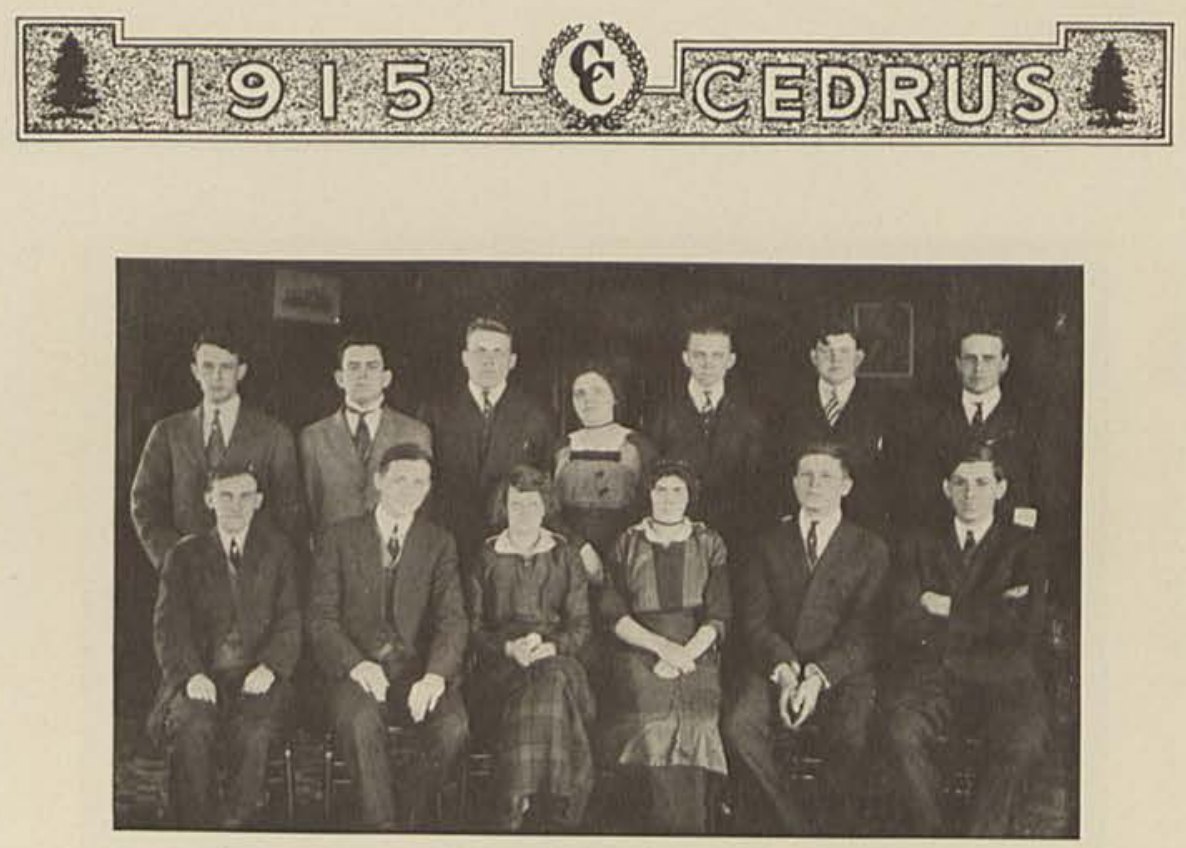

Debating Club

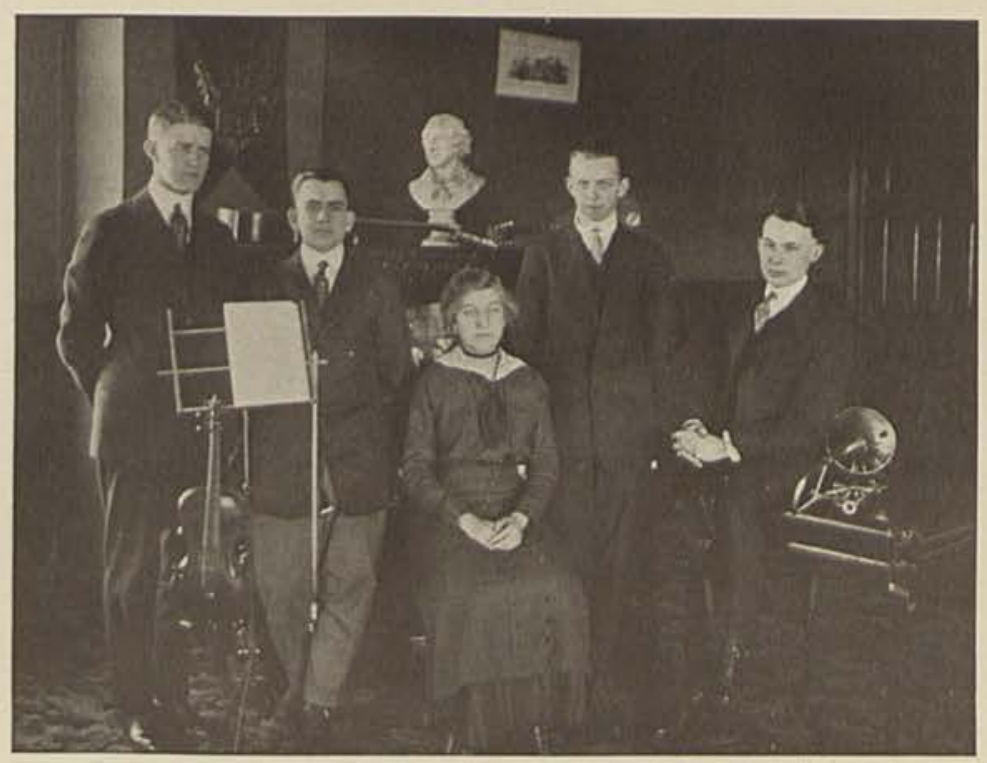

College Quartette 

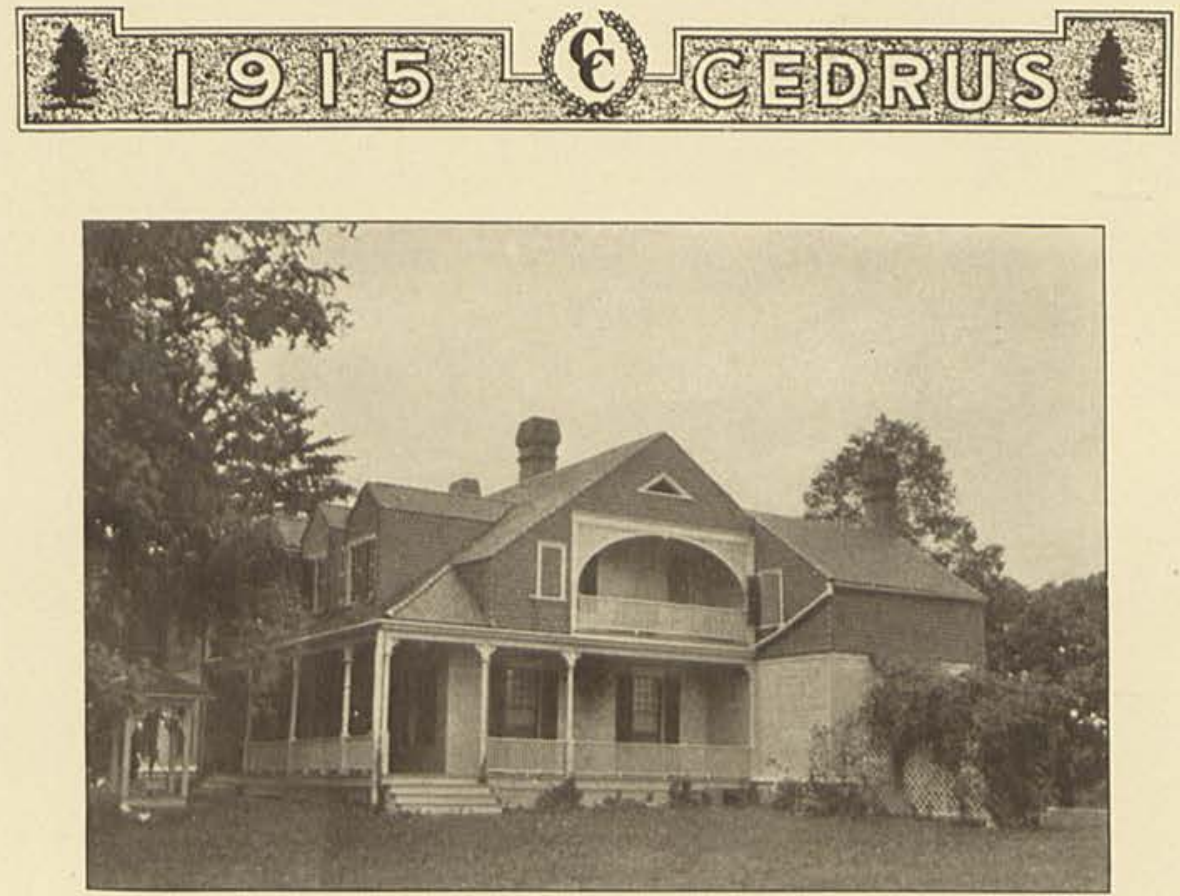

Whitelaw ReId Home

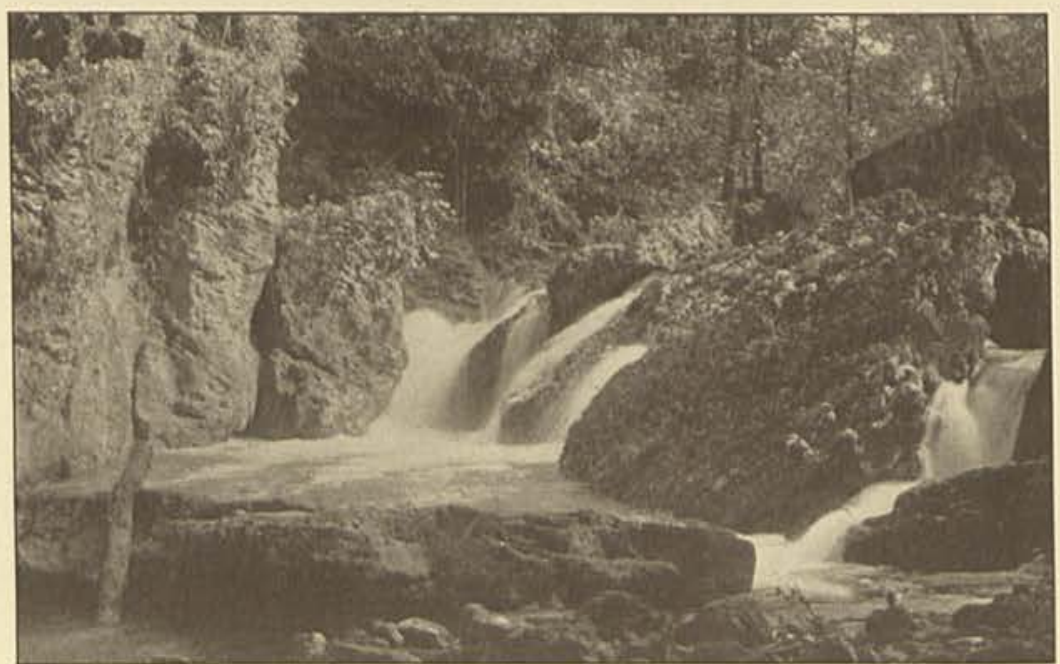

Where Nature Dwelles 


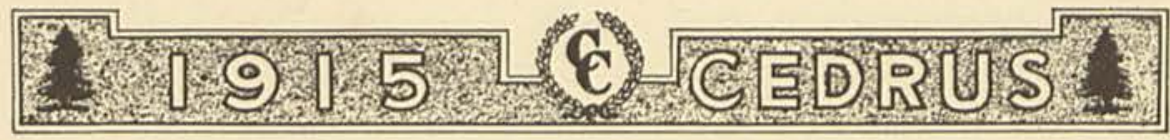

\section{The Cedar}

"Fairest of all," the Cedar,- - even thus

An old-time Grecian poet wrote of thee,

And e'en today, the world her tribute pays.

$\mathrm{O}$ spreading beauty! great in fortitude!

Sublime in everything that thrills the soul,

Thou art an emblem, grandest to behold,

A badge of honor with no marring stain,

For to the frost thou would'st not give thy green;

Thou would'st not bow down to its tyranny;

Nor would'st thou kneel before the mailed might;

But with thy fairest charms would stay the blade

That seeks to humble thee - and thy reward-

Of that thy virtue speaks with eloquence;

Wreaths for thy courage when the skies are dark,

And wanton clouds the sun's bright rays conceal.

Exalted are thy efforts, lifting helpful arms,

From out a soil that holds scant nourishment

To scatter cheer and warmth upon the earth,

In places, dark and drear to look upon.

Thy verdure fresh adorns the barren cliff

And summer's green, the snow-clad hills reflect,

O'er winter's power thou bear'st the victor's flag,

And in that day when earthly deeds are weighed,

Our God, Himself, shall speak with trumpet voice:

"Right nobly hast thou wrought, $\mathrm{O}$ noble tree.

Henceforth a crown of glory shalt thou wear." 

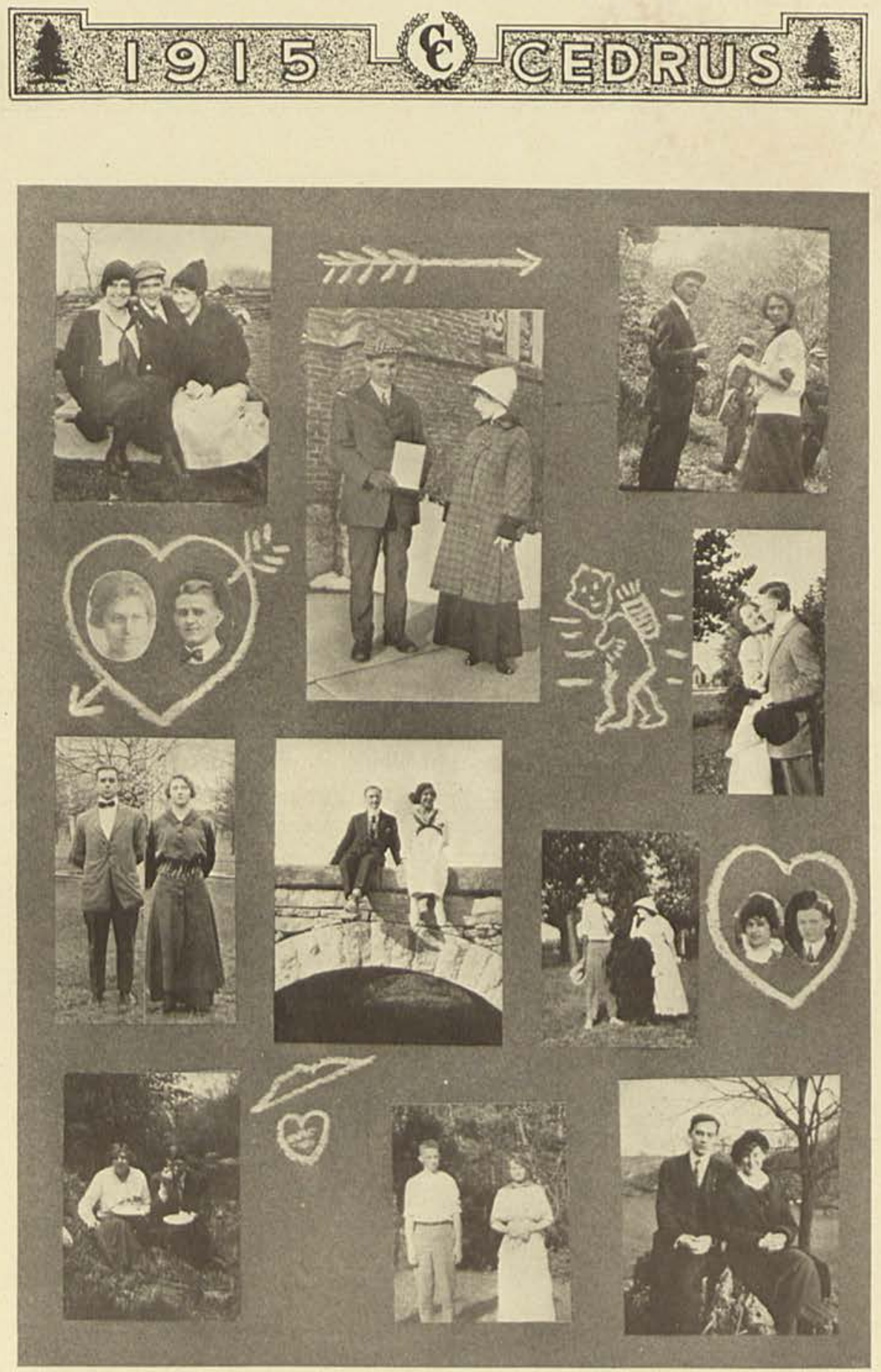

Too Good to Omit 

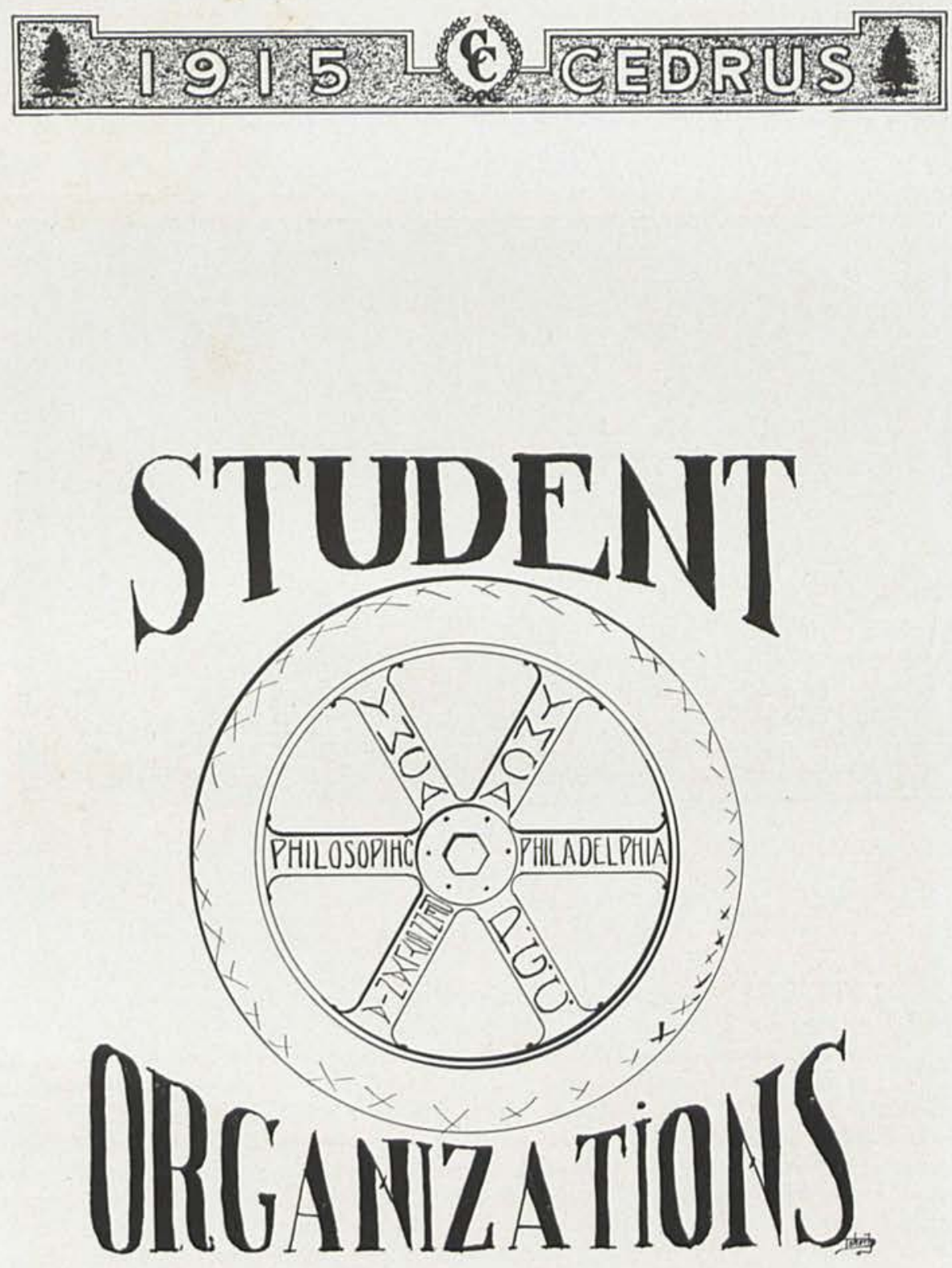

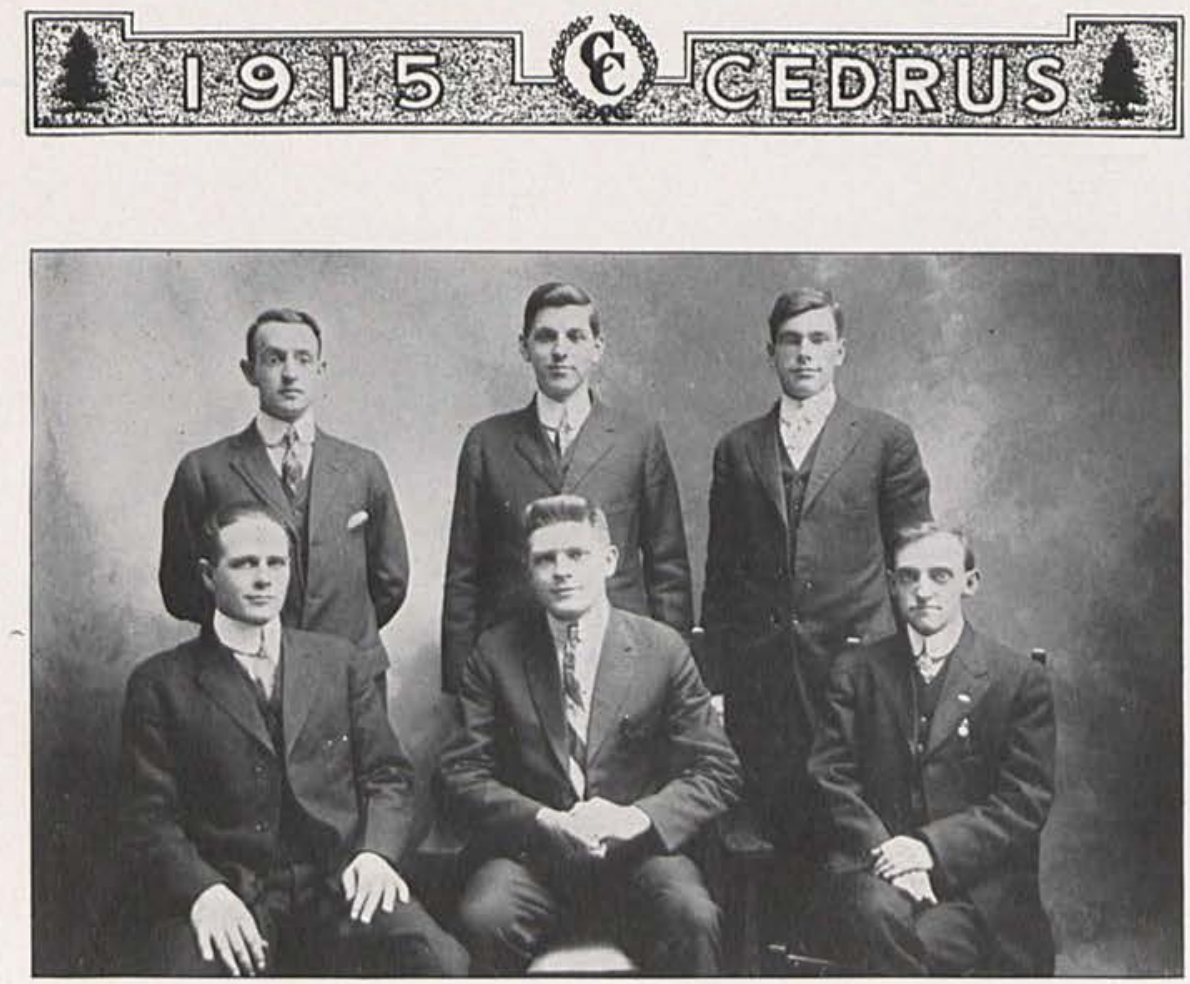

\section{Young Men’s Christian Association}

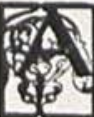

LTHOUGH our Association is not all we desire it to be, yet we feel that as an organization we may be justly proud of our history. From the beginning of the Association in 1906 until the present time we have had young men with us who were thoroughly consecrated to their Master. One of the first members of the Association, Mr. William Waide, is now a missionary in the Reformed Presbyterian mission field in India. Last September, another who was an active worker sailed as a missionary to China. Professor Lanning, as we shall always call him, although not a student, was nevertheless much interested in our work and we miss him. Besides these, a number of our men have entered the ministry and are engaged in active work for the Master. Several of the boys now in the Association are looking forward to the ministry.

Our meetings are held every Wednesday morning, and although we are sometimes few in number, we feel that we are benefited by meeting together for a few minutes of prayer and praise. This winter we have had a number of speakers. Rev. J. W. Patton brought us a helpful message on "Silent Influence." The week before vacation, we met with the Y. W. C. A. and had Rev. H. C. Foster, of Clifton, with us; and just recently Dr. J. L. Chesnut had a heart-to-heart talk with us as boys. The messages these men have left with us have been very helpful and inspiring.

Our new President, Wendell Duff, we were able to send to the Presidents' conference at Granville, Ohio, and he has come back filled with enthusiasm for the success of our Association. The way sometimes seems dark, but we have not given up hope, and are still hoping and praying that there may be better things for us in the future. 

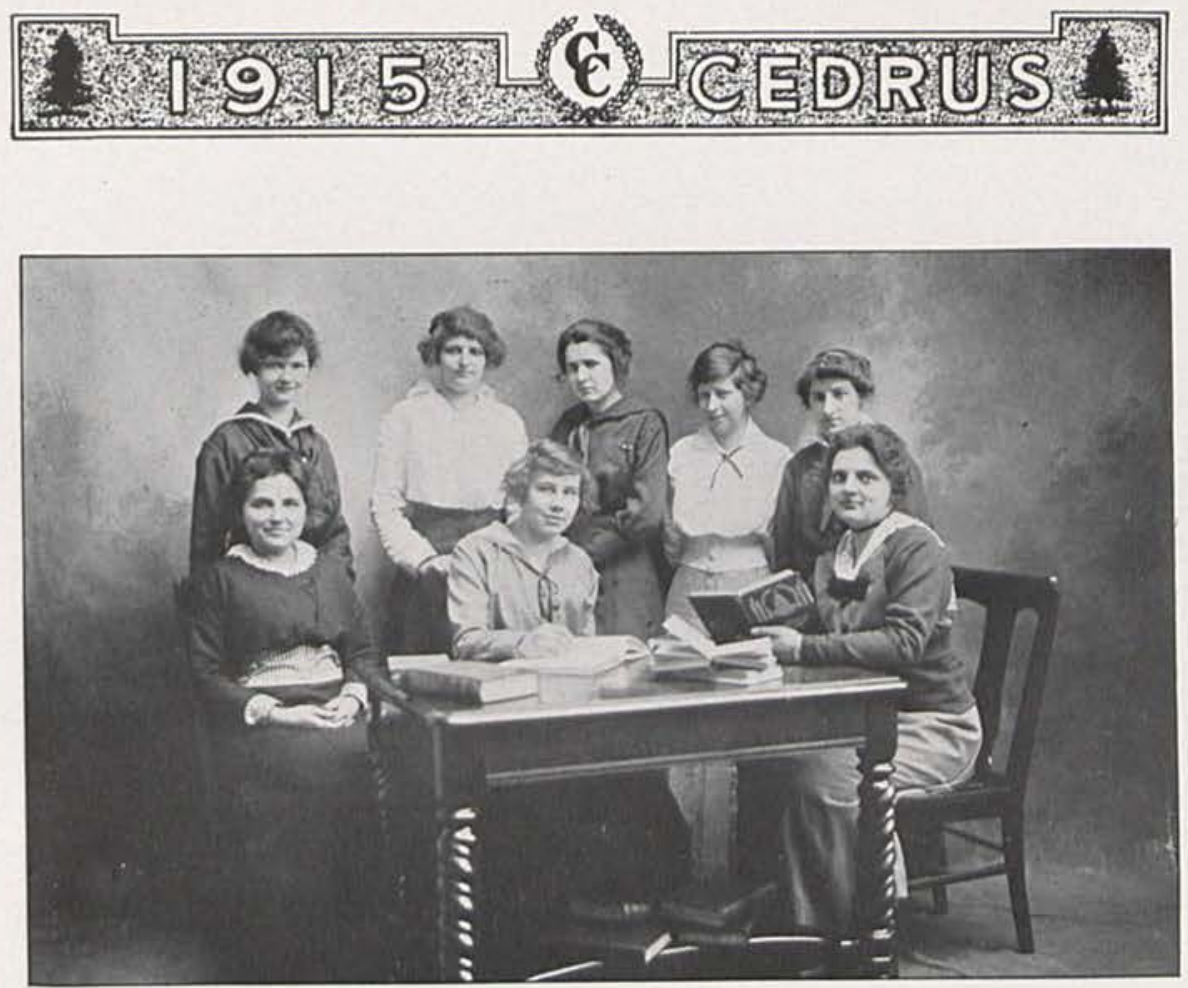

\section{Y. W. C. A. History}

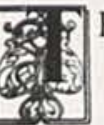

HE Young Women's Christian Association was organized April 8, 1909, through the efforts of Miss Agnes Jean Smith, then Professor of English, and Miss Helen Sewall, Student Y. W. C. A. Secretary at that time. The membership then consisted of all the girls in college; and at present a majority of the girls are members. Weekly meetings are held on Wednesday.

Although our organization has been small, we feel that we have at least been financially successful during the few years of our existence. First of all the girls furnished their rest room. The next winter one delegate was sent to the Rochester Convention. Two delegates were sent the following summer to the Territorial Conference at Granville. In October, 1910, the Association sent one delegate to a missionary conference at Athens. The following fall two delegates were sent to the Ohio Students' Conference at Springfield. The next fall, two girls were sent to a similar conference held at Westerville, Ohio, and last winter two delegates were sent to the Ohio and West Virginia Student Conference held at Dayton.

This year we have attempted more work of a practical nature than we ever have before. and thus far have been very successful. Six Thanksgiving baskets were filled with all the bounties of the season, and distributed to the needy of the village. The children of the poor families were remembered at Christmas with well-filled stockings. At present we have a "shut-in" committee whose duty it is to visit the sick and aged.

We are especially pleased with the interest which the girls have taken in the work this year. and the active part they have taken in our weekly prayer-meetings. Altogether we feel that we have a very bright outlook and that we will be able to accomplish greater things than ever. 

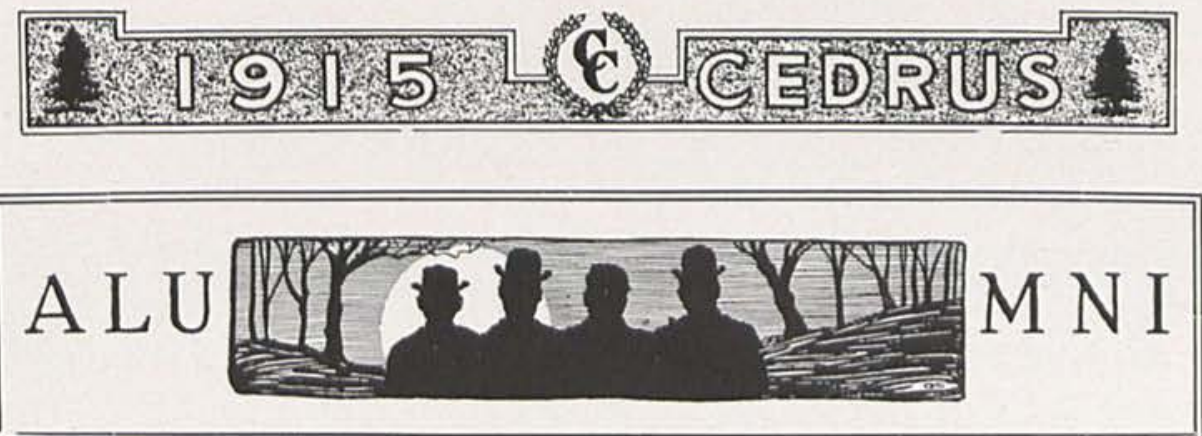

\section{Alumni}

PACE being at a premium, it will be necessary to treat this subject in a more or less general way. This fact makes a register as requested impossible. A classification dealing with the various graduating classes, as such, with a little "human interest" here and there, must suffice.

1897. How well remembered, although eighteen years ago, are the words (which have since become familiar to all), "upon the recommendation of the Faculty and by virtue of the authority vested in me by the Board of Trustees, etc." As they were repeated, forward, in turn, strode John Bickett, Raymond Gorbold, Homer McMillan, Cal Morton, and Alvin Orr and lo, a new Alma Mater sprung into being.

To these boys is chargeable most of the "deviltry" incident to student life in the college. They made precedents. All had attended college elsewhere, and each brought with him to Cedarville some of the spirit of other institutions. For instance, Ray Gorbold brought over from Franklin College the first white vest ever worn in this school. $\mathrm{He}$ wore it on all occasions. Homer and Alvin were in for literary work. As for $\mathrm{Cal}$-well, Cal faced the footlights once. It was in the Philosophic Hall. The piece was about a young fellow calling on his girl, and each verse wound up, "And you were scared, Old Man, and so was I," but Cal would insist on saying, "And so AM I." He made a big hit but never tried it again. As for John, he was considered the righteous soul that saved the class.

1898. Elmer Elder and Jim McQuilkin were the second annual product. Elmer lost his finger one Thanksgiving day. Stuck it in his gun barrel while hunting. This showed his wisdom. His careful training in college probably prevented him from looking down the aforesaid barrel. "Jim Mac" always wore his hair a la Bob La Follette, and was a favorite with the ladies.

1899. Jim Heron was the shining light of this class, with Tom Turner a close second. Belle Winter gave them both a chase for the money. Jim and Tom are pastors now. Belle, annually, makes a speech at the Alumni Association meeting to which it is well worth any one's time to listen.

1900. A record was made by the class of 1900 that has never been equaled by any class before or since. Note the list: "Nabob" Condon, who wore the newness off the College Hall; Rob Harper, who was the first to steal a fair member of the faculty (the loss was bad but the example has proven even worse): "Shope" Iliffe, famous at the time as left-hand egg-thrower, bell-ringer, and Captain of the Hallowe'en Raiders, '96, '97, '98, '99. Then there was Clode Paul and "Chick" Young, whose mere presence was a bad omen. Cora Anderson, Lulu Coe, Bessie Hopping, the Knott girls, Nell Lewis, Anna Orr, and Nell Ustick made up the list of the girls.

Summing up briefly: in the fall, the Trustees ordered the college redecorated and all pianos tuned. 


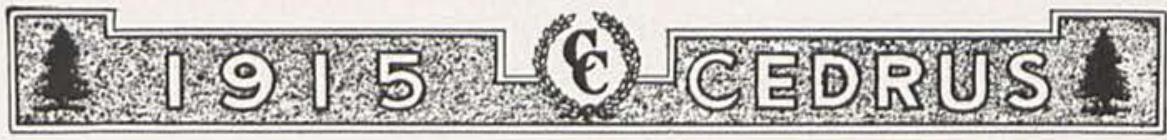

1901. This class was noted for its diversity. "Des-cartes" Harper was crippled up with the rheumatism; "Bob" Wilson with "argumentitis." "Deacon" George was one of Dr. McKinney's "too-tooters" (two tutors). E. E. Finney refused to use ponies. Fred Anderson's fast stepper took most of his time. As for "Bob" Galbreath, Olive Coe, and Blanche Ervin, they labored under the bad example of the former classmen.

1903. What this class lacked in numbers was made up in importance. Homer Henderson didn't exactly hate himself, due possibly to the reform tendencies of Mary Ervin, the other member of the class.

1903. Vera Andrew (of tender age), Alice Bromagen (her Professor's delight), Alfaretta Hammond, Lulu Henderson, and Agnes Stormont (the studious), John Finney (right guard), John Wilson (of sunny disposition), and Cal Wright (on knowledge bent, since knowledge is power), had their day, faced the orchestra for an hour, and straightway went forth-as Jay Wolford was wont to say - "to battle with the elements."

1904. It is not often that so much native ability is found in one class as was found associated in the one of this year. Besides, each individual was a specialist in his or her particular work. "Windy" Bull still holds the "talk" title. "Speedy" Bird, as the name signifies, was not slow, but to date is still single. R. B. Shaw showed Joe Jefferson tendencies, but later turned his attention to distributing Bibles in Texas, with a sixty per cent rakeoff. Fritz Barber excelled as a debater of current topics. Ray Fitzpatrick, alias "Fitz," was punctuality personified. He never missed a minute in all six years' attendance of classes and was always exactly thirty minutes late to football practise. Carrie Hutchison was a leader in society and one of the few successful heartsmashers in the historv of the college. Frank Young was an orator of no mean ability. "Bill" Pollock rapidly developed theological tendencies, also matrimonial. Marie Garlough. Mary Ramsey, and Carrie Rife worshipped at the feet of the masters.

1905. Since the statute of limitations does not run against crime, in this state, even at this late date it would surprise no one should the grand jury investigate this class and return a bill against it for obtaining money under false pretenses. Any one who attended its Class Night exercises should be a competent witness. Sam McMillan was compelled to deliver fourteen declamations before the crowd was appeased. No wonder Sam had (?) to read his graduating oration the next day. The rest of the program consisted of a discussion and demonstration about a hunter chasing a squirrel around a tree.

1906. The responsibility for a major part of the purloining of chickens, roomstackings, and practical jokes played on faculty and fellow-students, for several years was laid at the door of the members of this class; and perhaps justly so. All manner of things happened along about this period. "Jack" Graham's trunk would turn up on the front porch of his best girl's boarding house; Gordon Ware's room would become uninhabitable with sulphur fumes; Mr. Crawford's annual donation of chickens would become "invested in the donee"; "Prexy's" library sprung up in a night; et cetera, et cetera: and of course the blame always attached to this "bunch." 


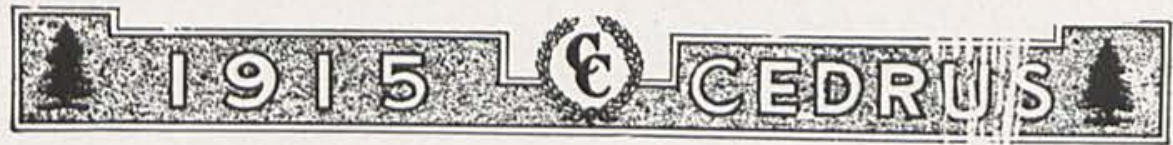

1907. Night prowling was the principal diversion indulged in by the "grads" of '07. It was no uncommon thing for the Marshall brothers to call some boastful one's bluff by taking him out to Jackson's track at any old hour of the night and kick dirt in his eyes. Others of the class contemplated midnight plunges in Massie's Creek, which fortunately were never realized.

1908. "Jack" Nash bears the reputation of keeping company with a greater number of ladies than any other man who attended college. "Jack" Henderson and "Doc" Spahr possessed enough impracticable mathematics and philosophy to stall a sixcylinder. The remainder of the class were of course very much outshone.

1909. Initiative in man is a laudable thing but it can be carried too far. Individually the class of ' 09 were always starting something they couldn't stop. Since graduating, a radical change has apparently taken place. Nothing startling has been heard from them. Like that automobile of well-known make which ran twelve miles without its engine, this class's reputation is all that is necessary, it seems.

1910. This is the banner class of the college-the largest in number. Just notice a few of the individuals. "Dave" Brigham of snipe hunter's fame-by the way, this is the best story that ever happened in college circles. It was in the fall of '05. "Billy" Beggs had drifted in from York state and "Dave" hailed from Philadelphia. Aunt Mary's boarding club was flourishing in those days. About a month after the fall term had opened some one suggested that a mess of snipe wouldn't go bad. In a night or two, about a dozen of the boys proceeded to the lonesome vales on the Whitelaw Reid farm. Of course "Billy" and "Dave" being from the city didn't know anything about driving snipes and it was up to them to hold the sacks.

Well, about 1:30 a. m. they began to do some thinking. They then proceeded across the fields and finally came out onto Bridgman's race track. Thinking it the road they plodded their weary way, but the third time around the fence posts began to look familiar. The truth dawned upon them about this time and seeing a house nearby, they awoke the sleeping inmates and inquired for a hotel in Xenia. "Xenia? Man, you are in Cedarville," was the reply. With this added enlightenment and chagrin they soon found their rooms. The experiences of this memorable night were never fully divulged until about three years afterwards.

Franklin Archibald Creswell developed enough good stories during his regime as Manager of the basket ball team to fill a volume. If "Archie" were to write such a book he would no doubt devote "steen" chapters to the virtues of his favorite coach.

"Sam" Hill was the "Big Man" of the class. His football record has never been equaled. If the reports from Carnegie Tech are true, he is the coming White Hope.

"Bill" Ritter was a pugilist. He was the undisputed champion until a man who believes in "trading at home" came to town. The next day "Bill" gave his gloves away.

"Ed Shaw was the "long" boy of the institution, excepting Professor Jurkat of course. "Ed" made inroads on the faculty - a little. 


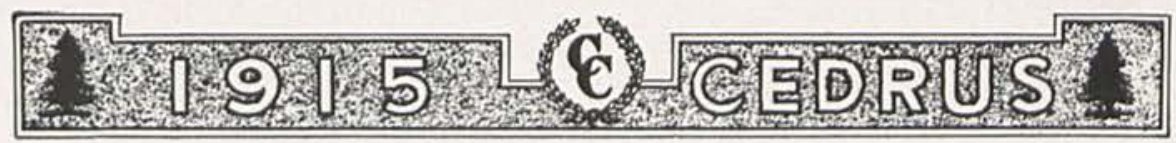

Some of the best wives turned out by the college were graduated this year.

1911. The members of ' 11 were all akin. (See Jurkat for further particulars.) John Stewart early developed musical talent. John devotes his time at present to setting Luke McLuke's stuff to music. "Jack" Ustick was "going good" until he spent the summer at Miami Valley Chautauqua. No living man could tell the rest. As for the girls in the class-well, "Jack" got R-e-v. prefixed to his name last spring and he couldn't leave Lydia. The others are still "living in hopes."

1912. These youngsters came within an ace of raising enough funds to erect a dormitory for the college. Ask your poker player friend just how near that is. However, it was a stride in the right direction, and the experience gained has placed "P. Dix" in the champion list of money raisers.

1913. As a class none have won more medals than this one. Wendell Foster and Earl McClellan have more medals and ribbons hung to them than a sweepstakes Jersey that has made the rounds of the county fairs. The remaining members are respectable and law-abiding citizens.

1914. The deeds, both good and bad, of this last and infant class of graduates are still fresh in your minds. One of this number is married already, which is laudable.

This brings to mind an interesting fact. Of the male graduates two-thirds are married, while only one-third of the woman graduates are married. Perhaps it would be a good idea to continue the Domestic Science Department. 

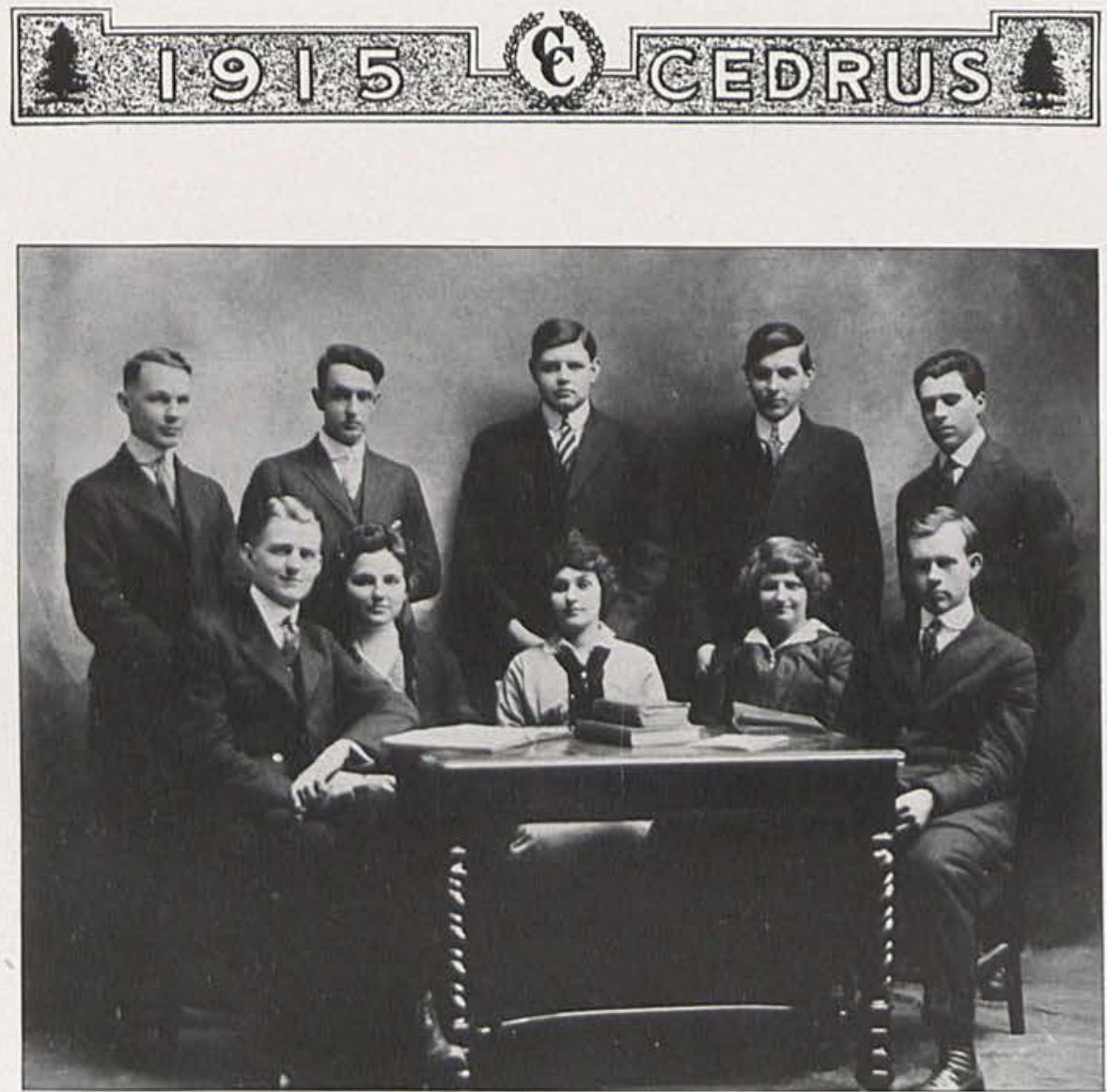

\section{Gavelyte Staff}

W. D. Sterrett

Editor

RALPH S. ELDER Associate Editor

W. EMERY HOSKINSON

RUTH R. HARRIS

Society Editors

MARY E. BIRD

David BradFute

Local Editors

R. Cecil Burns Business Manager and Treasurer

Assistants

J. R. MCCORKELL

David Bradfute.
H. F. BIRD

Subscription Manager 

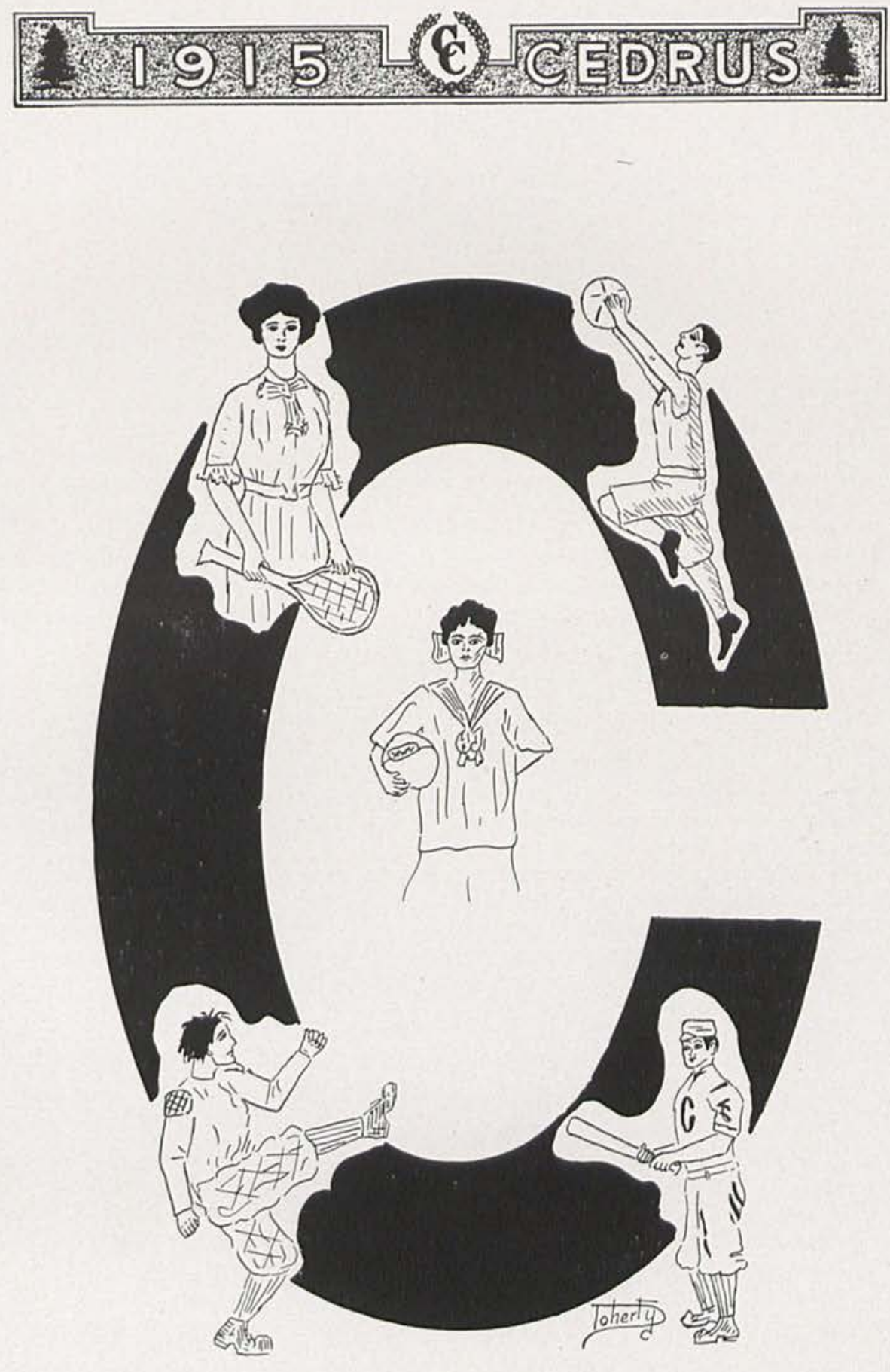


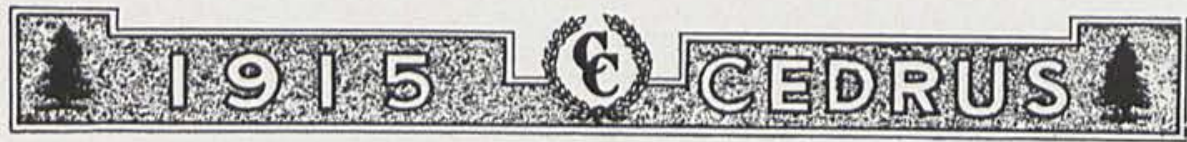

\section{The Stadia}

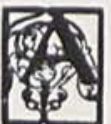

LTHOUGH Cedarville College is a comparatively young institution, the history of her athletic ability is something of which she may justly be proud. To be sure she has had her up's and down's, but the red days have far excelled the black. From the first she has manifested an active interest in all athletic sports. In looking over her records, we find that for three successive years, beginning with 1896, she held the championship in baseball and football over all the surrounding Colleges. The football record for 1897 shows seven victories, two tie games, and not a single defeat. On the team were Morton, Orr, the Iliffes, and a number of others who are now playing the game of life with the same zeal with which they played football.

In the fall of 1902, Dr. Alford presented the College with a much-needed gymnasium. Immediately the basket ball teams were reorganized and practise commenced. Ever since there has been an active interest in basket ball, both by boys and girls. Although there have been failures and are yet, still there has been steady advancement. In the winter of 1910-11 the girls held the championship honors of the state. That year they won every game but two and were successful in defeating the Miami University team that had not been defeated in nine years. Our boys' team has also always had a good record.

Owing to the fact that all our players were new, some of them having never played before, the teams the past winter were at a disadvantage. However, their attempts were not all defeats, and even the defeats have only served to show them their weak points, and enable them to strengthen themselves more and more for each succeeding contest. Both boys and girls have done some splendid work, and the outlook for next winter is very encouraging.

Early though it is, the boys are already enthusiastic over baseball, and are receiving every encouragement from the student body. There are several good players in school and the prospects are brighter than they have been for two or three years.

Besides baseball and basket ball, we also have a fine tennis court, and a number of students who are much interested in that sport. During the sunny days in the autumn and spring the court is nearly always occupied, and much enjoyment is obtained from the game.

While in some ways the past year's record has not been very good, the outlook for the development of athletics in our College was never more promising and we are anticipating better things in the future. 

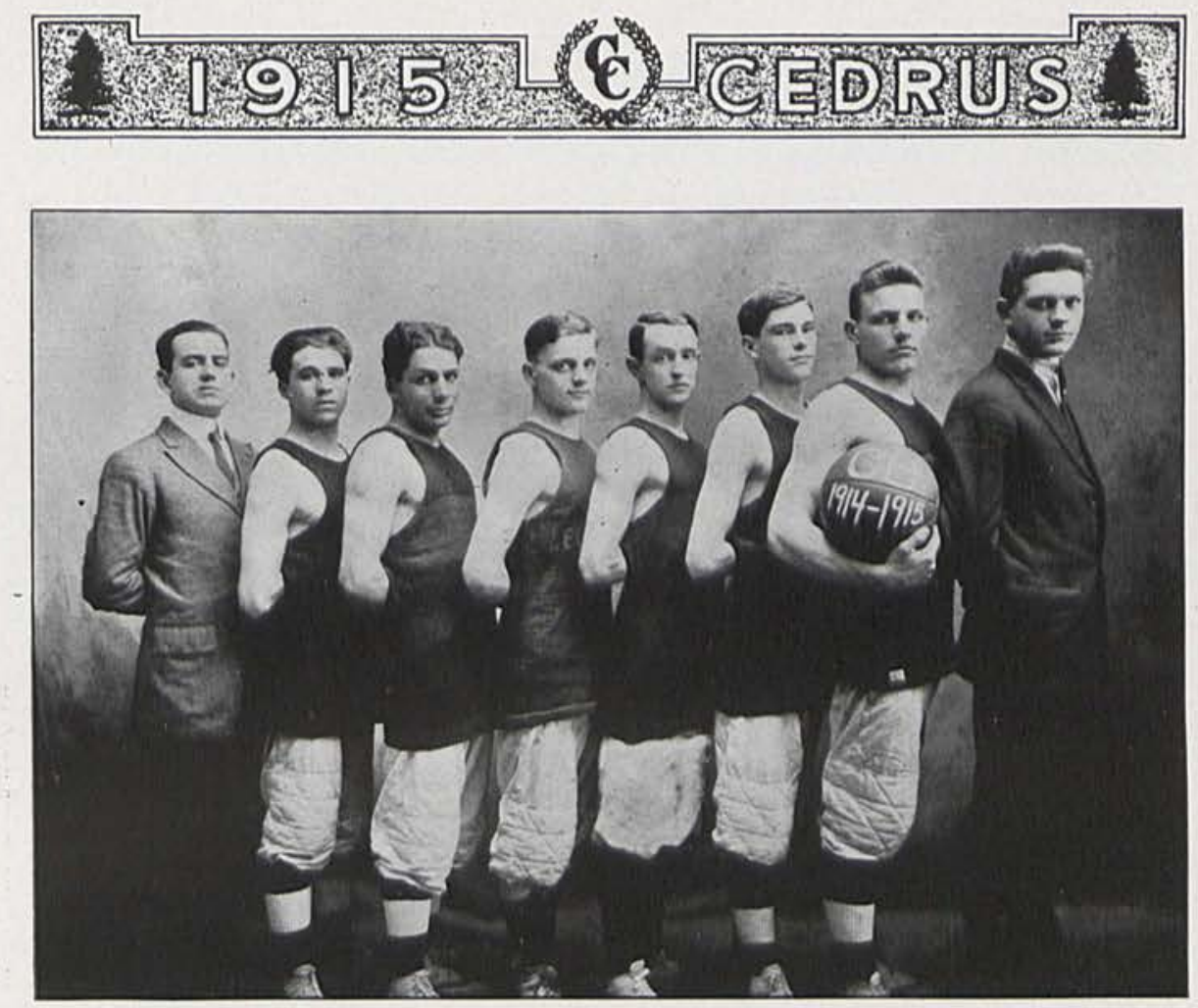

"They hitched their wagon to a star but the single tree broke,"

\section{THE BASKET BALL TEAM}

The basket ball season came in like a goat and went out like a - ? We lost the first game and at the present writing expect to lose the last. Sh! - say! I'll tell you somethin' if you won't tell anybody.

There was a basket ball game down at New Straitsville, January 22, and six Cedarville boys went down to see it. Selah. The more we think of it, the madder we get.

But, gentle reader, let me reason with you a while. We will have practically the same team for the next three years. They ought to learn to play ball by that time. Anyhow I'll bet you five peanuts and a half, you'll see better basket ball here next year than you did this.

Hans.

P. S.-We didn't lose every game.

H.

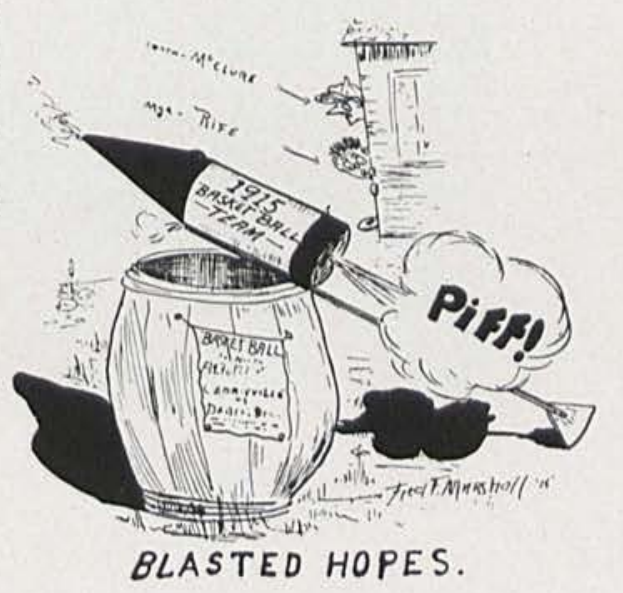



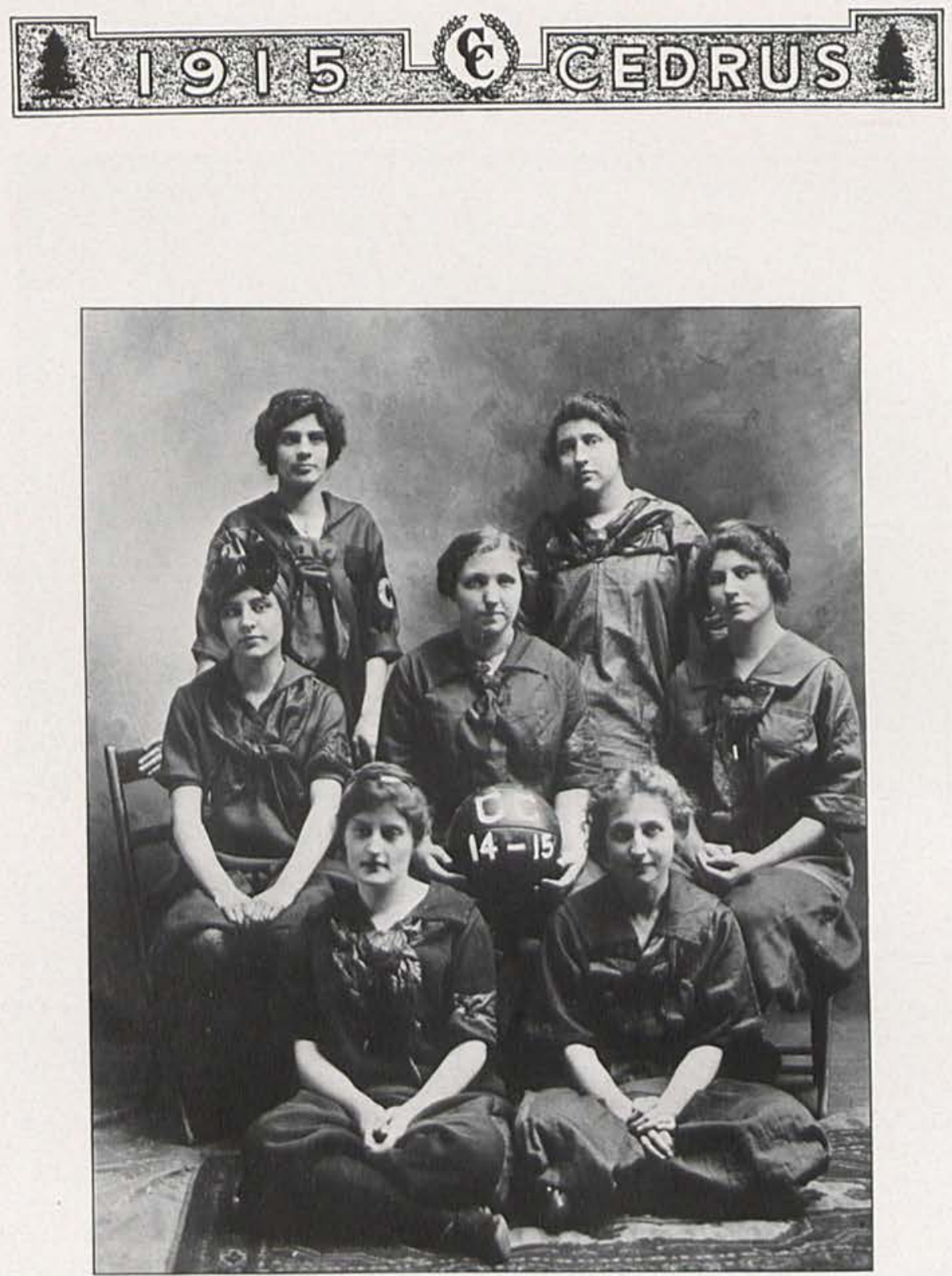

GIRLS' BASKET BALL TEAM

BURNS

WRIGHT

SOMERS

GARDINER

CoLlins BAUMGARDNER 


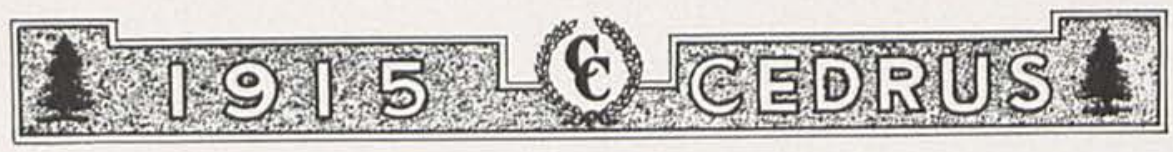

\section{Girls’ Basket Ball}

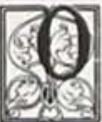

NE morning last fall, after chapel services, Prof. McChesney read the following announcement: "All girls wishing to play basket ball, come to the gymnasium at two-thirty this afternoon." Long before two-thirty that afternoon you could see girls hustling up street and entering the door of the gymnasium. The last one to come was a shy little personage wearing a big happy smile. As she entered all the girls greeted her with this welcome: "Hurrah! a new girl for the basket ball team." Immediately you could see her smile vanish, and after a few sobs and stammers she said, "I'm the coach." After this blunder, the girls kept quiet and the coach began to arrange the team. First she selected two small, (?) delicate (?) girls for centers, namely, Miss Somers and Miss Little, and the fleet-running Miss Baumgardner was chosen as a second center. Next, guards were chosen who upon first appearance brought to our minds the familiar forms of "Oscar and Adolph." These were our worthy friends, Miss Wright and Miss Collins. Last, but not without due consideration, forwards were chosen. Miss Burns and Miss Gardiner, two stalwart, rosy-cheeked farmer girls were selected for this position. The team having been arranged, the first practise began. It resembled a football skirmish more than a girls' basket ball practise. At four o'clock the girls started for home adorned with black eyes, bruised knees, and strained wrists. From this time on there was great improvement in appearance as well as in practise; and although we have unpleasant memories of the slick ball-room floor and dreadful "hootenannie" of Greenville, our attempts have not all been failures, and who knows that there is not greater success in store for us.

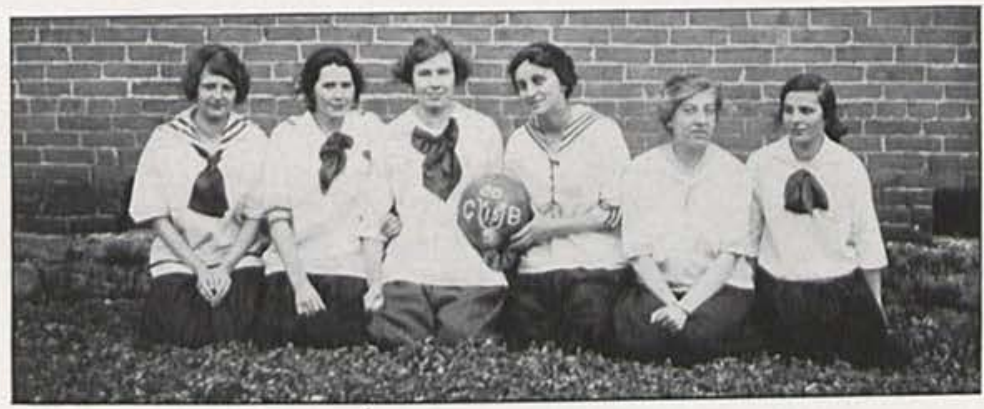

Girls' Basket Ball. Team-Cuss '15 

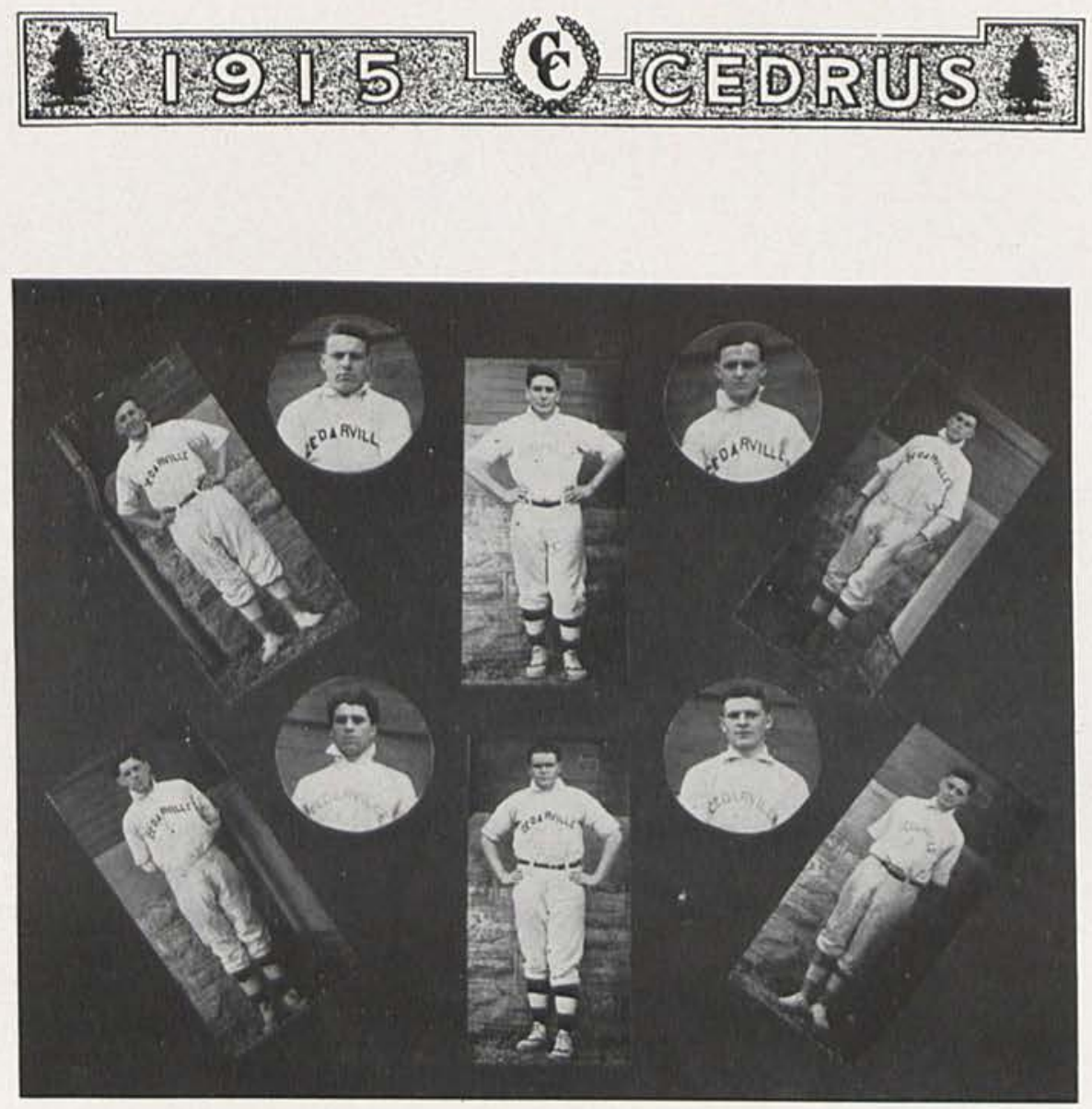

Baseball. Team 15

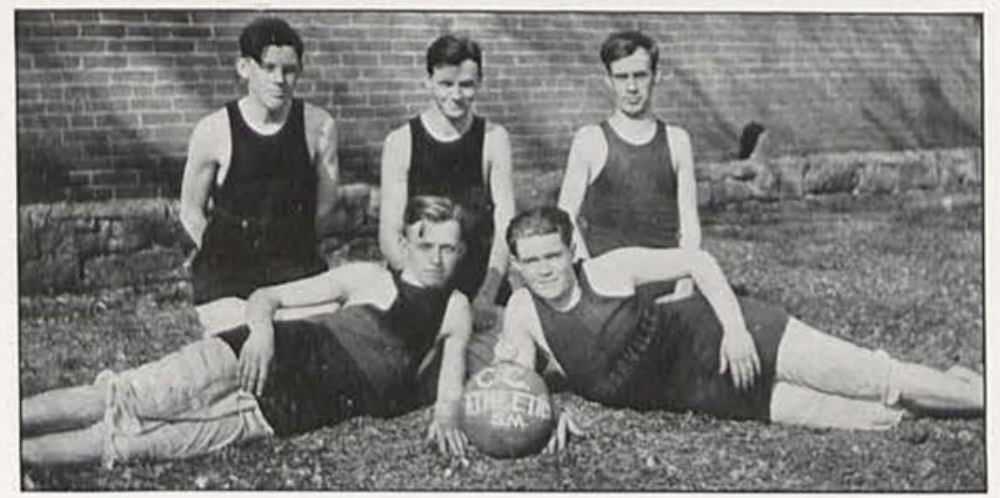

Boys' Basket Ball-C. C. Athletics 


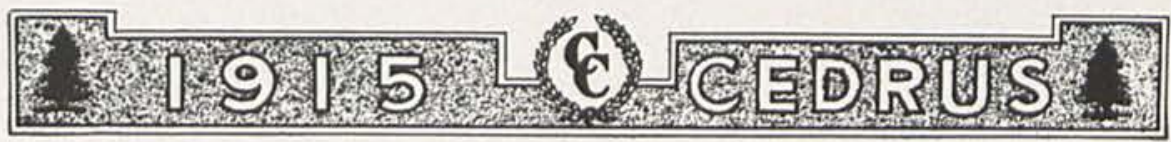

\section{Cedarville Theological Seminary}

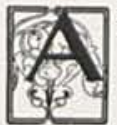

T a meeting of the Reformed Presbytery of North America held in John Thompson's home, Conococheague, October, 1807, a committee consisting of the Reverends Gibson, Wylie, and McLeod, were appointed to inquire into the necessity for establishing a Theological Seminary, if such necessity existed, and to outline a plan for the inspection of the Presbytery. On the following day the committee reported the need of such an institution and presented an outline of the plan. The Presbytery considered the articles of the constitution, and with some amendments adopted them.

The Seminary was to be located at Philadelphia. Rev. Samuel B. Wylie of Philadelphia was unanimously elected Professor of Theology and Messrs. Gibson, Black, and McLeod, Superintendents for the first year after its organization. The Superintendents met with the Professors in Philadelphia, May, 1809, to organize the Seminary and make all necessary arrangements. No students had presented themselves. A committee appointed for this purpose reported that the amended draft of the constitution had not been published and that they had not made an appeal to the church in general, for pecuniary aid. The suggestion was made that the Seminary be removed from Philadelphia to Walkill, but the opposition of Mr. Wylie was so decided that it was thought best to continue its seat in Philadelphia. The Board of Superintendents were instructed to meet with the Professors in Philadelphia in 1810, and to exert themselves in behalf of the institution. Mr. Gibson having declined to serve as a Superintendent, Rev. Gilbert McMasters was appointed in his stead, and the Seminary was organized May 25, 1810.

Rev. S. B. Wylie, D.D., was its first, and for many years, its only Professor. The number of students who attended was comparatively large, but it was not sustained by the church with the interest which it should have excited. It was therefore suspended for several years, but its usefulness being generally acknowledged, it was revived in 1823, and its former Professor appointed to take charge of it. The controversies that agitated the church and finally resulted in the division of 1833 affected the Seminary so injuriously that it was again suspended. In 1844 it was reorganized with Dr. S. B. Wylie as Professor of Theology and Dr. Samuel W. Crawford, Adjunct Professor. The course of instruction was to occupy four successive annual sessions, each session to be of four months' continuance, from the first of December to the first of April.

In 1850, a second Theological Seminary had been organized at Xenia, Ohio, with Dr. McMaster, Professor of Theology, and Rev. Hugh McMillan, Assistant Professor. When the Wylies, father and son, resigned in 1851, the Philadelphia Seminary was removed to New York and Dr. John N. McLeod was appointed Professor of Theology. In 1854 General Synod decided to unite the eastern and western Seminaries and locate the institution at Philadelphia. In 1863 Dr. David Steele began his connection with the Seminary and held it until 1906. Rev. Matthew Gaily was elected Professor of Hebrew and Greek in 1876, and continued to teach until his death in 1902. In 1890, Dr. I. Y. Boice was elected Professor of Homiletics, Church History, and Pastoral Theology. In 1903 Dr. James D. Steele was elected Professor of Hebrew and Church History. In 1906, Rev. W. J. Smiley of Sparta, Illinois, was elected Professor of Hebrew and Church History.

In 1913 the Seminary was removed to Cedarville, Ohio. Dr. David McKinney, Dr. W. R. McChesney. Prof. F. A. Jurkat, and Rev. Leroy Allen were appointed Professors. In 1914, Dr. McKinney resigned and the work in his department was taken up by Dr. McChesney. 

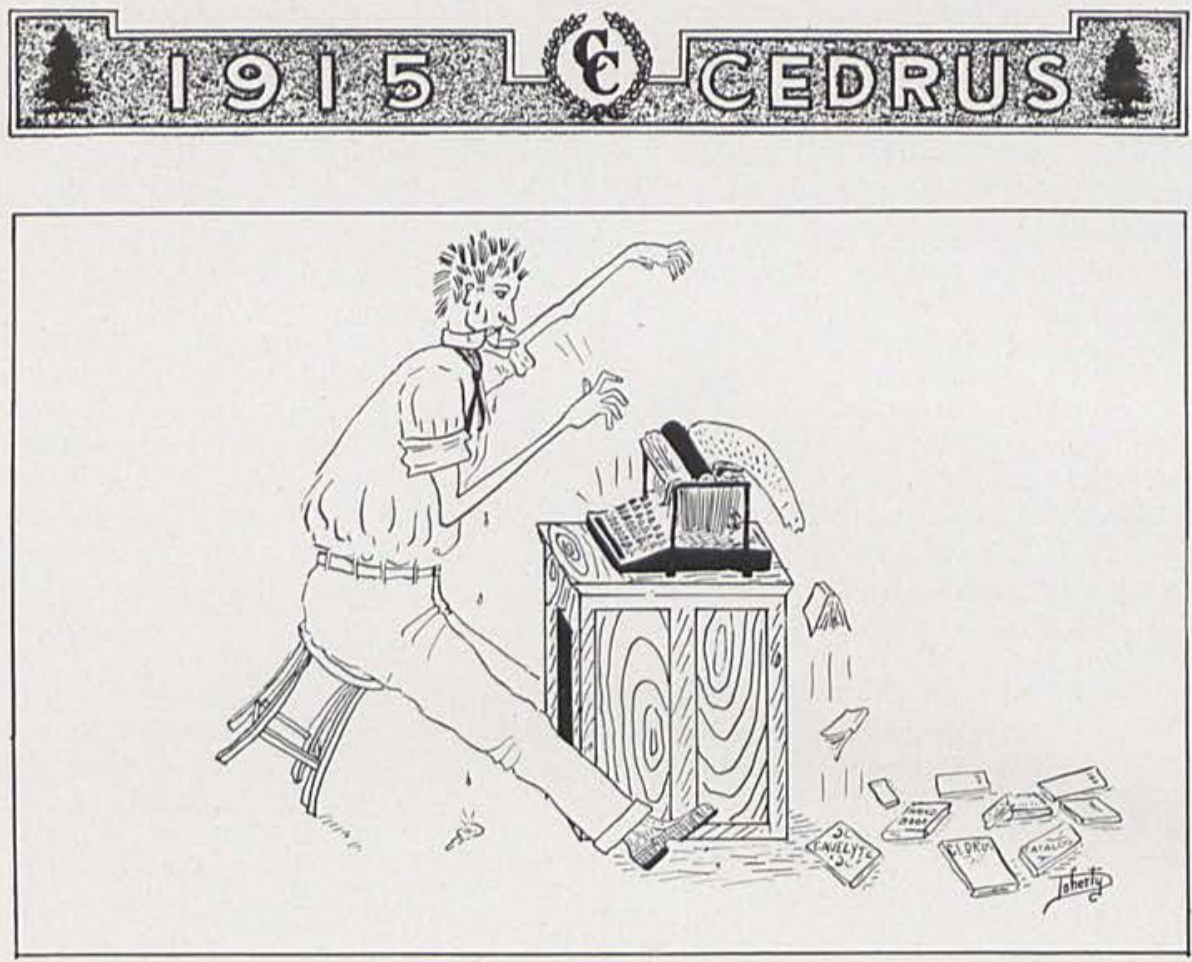

\section{College Publications}

THE GAVELYTE

HE GAVELYTE is the student publication of Cedarville College. Established in 1906, it has survived many difficulties and discouragements, and still continues to herald the events of Cedarville College to the students, alumni, and friends of the institution. Although the circulation is not large, we have received a great deal of help in the way of advertising, from the business men of Cedarville and surrounding towns. Mr. Karlh Bull, the publisher of the "Cedarville Herald," has alse stood as a friend through sunshine and storm. We wish, through this publication, to thank all our friends for their support in the past and bespeak their continued support in the future.

\section{"THE CEDRUS"}

"The Cedrus" is the fourth annual that has been issued by the students of Cedarville College. The previous ones were "The Imago," 1897; "Memorabilia," 1903, and the "Gavelyte Annual," 1911. The new name has been given to this annual with the hope that it will be permanent, and that "The Cedrus" will be in reality an annual publication of Cedarville College.

\section{THE CATALOGUE}

The work offered by Cedarville College is fully described in the yearly catalogue. This year it has been combined with the Seminary Catalogue and will be by far the largest and best ever published by the College. 

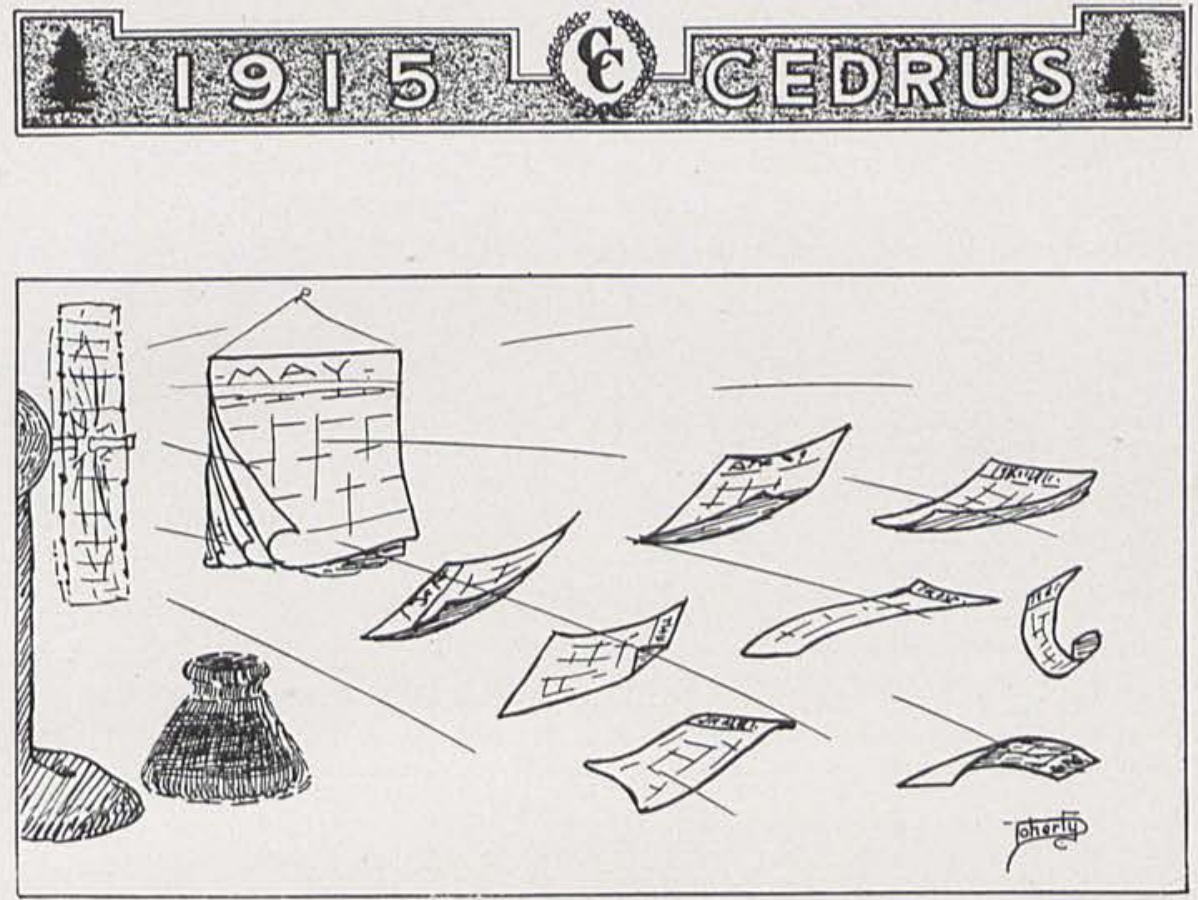

\section{The Calendar 1914-15}

MARCH 17. "St. Patrick's day in the morning." The table at Fort Dallas handsomely decorated in honor of Mr. Whyte.

MARCH 18. The decorations still remain.

MARCH 22. Mr. Willard Ritchie preaches in the R. P. church.

March 23. "Kid Party" at Ramsey's. "The Ride of Paul Ramsey" now a classic in the history of C. C.

MARCH 24. The "Kid Party," the main topic of conversation.

MARCH 26. "Bill" Collins, in rhetoric class, vividly portrays a sleigh-ride party of the C. C. student body in 1965.

MARCH 27. Emma Randall presents "Christmas Day in the Morning," "Aunt Jane of Kentucky," and the court scene from "The Merchant of Venice," at the opera house.

APrIL 1. The play, "A Kentucky Belle" presented by the Seniors.

ApriL. 3. Miss Cresswell and Miss Orr entertain in honor of Misses Boyd and Patton from Muskingum.

APRIL 4. Great excitement over sale of seats for the minstrel.

APrIL 6. C. E. social at the R. P. church.

APRIL 7. The minstrel show. Quite a hit.

APRIL. 8. Freshman spread at Ramsey's. Cake mysteriously disappears but the Freshmen not to be outdone, eat soda crackers.

APRIL 9. Second presentation of the minstrel show.

APrIL 10. Seniors present their play at Cliffton.

APRIL 12. W. P. Harriman, 12 , preaches in the R. P. church.

APRIL 14. Baseball practise begins. "Sophs" and "Freshies" gloriously entertained at Collins's by "Bill" and Dorolhy.

ApriL 21. Girls' spread at Bird's.

ApriL. 22. Xenia H. S. I, C. C. 27. Baseball.

APRIL 23. Shakespeare night. Selections from "Othello," "Merchant of Venice," and "Midsummer Night's Dream."

APRIL 24. Everybody good. Visitors from Ohio State University.

APRIL. 28. Cards distributed, "Everybody Go to Church Sabbath, May 3." 


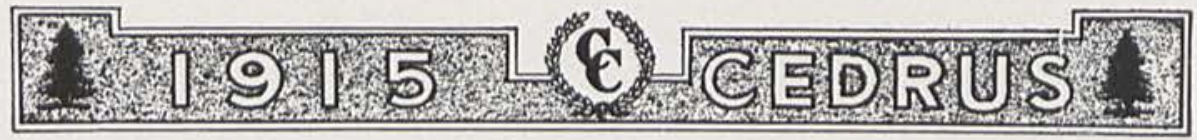

APrIL 29. Special chapel services in honor of Dr. Alford.

APRIL 30. Senior supper at Bruce Anderson's.

MaY 1. Prof. McChesney attends the funeral of Dr. Alford.

MAY 2. Everybody tagged, "Going to Church, May 3."

MAY 3. "Go-to-Church Sabbath." Everybody goes. (?)

MAY 5. Music recital at the college by Miss Helen Oglesby and Miss Mildred Crouse. Freshmen plant their flowers on the campus "by the light of the silvery moon."

MAY 6. "Sophs" especially interested in the flower bed.

MAY 7. Preparation for Cedar day.

MAY 8. The usual Cedar day weather. The "best ever" nevertheless.

MAY 9. The dish-washing commiltee clean up the dishes and also the left-overs.

MAY 10. Rev. Patton preaches the High School baccalaureate sermon.

MAY 13. Senior prayer-meeting.

MAY 14. High School commencement. Rev. Rourke, the orator.

MAY 15. Senior picnic at the cliffs.

MAY 18. The Seniors are missed from college.

MAY 19. Miss Mary Hastings entertains the Seniors for breakfast.

Mar 21. C. E. social at Mr. George Cresswell's.

MAY 22. Freshmen entertain the "Sophs" at the Clifton cliffs.

MAY 25. Fort Dallas "bunch" entertained on Miller street. The hickory-nut cake actually becomes a reality.

MaY 26. College crowd entertained at Corry's.

MAY 28. "No more Latin or Greek or French, no more sitting on a hardwood bench."

MAY 29. Preparations made for Decoration day.

MAY 30. The play, "Andersonville Prison," given in the opera house.

MAY 31. "Prexy" preaches the baccalaureate sermon.

JUNE 1. Senior play at the opera house.

JUNE 2. Faculty Reception at the library.

JUNE 3. Music recital at the college.

JUNE 4. Prof. Lanning takes to himself a wife on his homeward journey. Special exercises in honor of C. C.'s Iwentieth birthday. Alumni banquet at the library. "Sophs" entertain the "Freshies" at the college.

JUNE 5. Seniors get their "sheepskins" and an honorable discharge. Rev. Charles Sumner

Brown of Cincinnati, the speaker.

JUNE 6. "Parting is such sad sweet sorrow."

JUNE 7-August 18. Cedarville crowd dispersed; some to their pa's corn and hay fields; others to their ma's kitchen; some to school; and one or two, canvass books.

August 19. IMPORTANT DATE. Prof. Allen, not to be outdone by Prof. Lanning, com-

mences work in double harness, near East Liverpool, Ohio Prof. McChesney helps him get hitched up.

August 20-September 6. Nothing of importance.

SePtember 7. "Young hopefuls" bid good-bye to father and mother and leave for Cedarville. Activities begin with the arrival of the six-twenty train.

SEPTEMBER 8. Everybody busy unpacking, having schedules arranged, getting books, meeting new friends-to-be, and renewing old acquaintances.

September 9. Rev. Dr. Flynchbaugh of Cincinnati, delivers the opening address. Mr. Woodbridge Ustick and Miss Lydia Turnbull, both members of the class of 1911, are made one and inseparable.

SePtember 10. Work begins.

SEPTEMBER 11. C. E. social and reception at the R. P. church. Everybody gets acquainted with everybody else.

SEPTEMBER 12. Everything quiet.

SEPTEMBER 14. Setlled down to earnest work.

September 16. Prof. Lanning and wife unexpectedly arrive for a short visit.

SEPTEMBer 17. Prof. Lanning and wife leave for San Francisco.

Septemeer 18. Professors Allen and McChesney in Columbus. Philadelphian literary reception. September 19. HOT. HOT. HOT.

September 20. Temperance campaign begins. Prof. McChesney, Rev. Patton, and Rev. McMichel, each give ten-minute temperance talks.

September 21. Prof. McChesney requests that the singing be done in a low tone. Bitter disappointment.

SEPTEMBER 25. Philadelphian literary reception. 


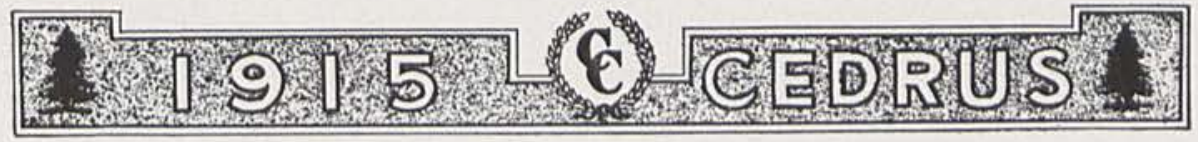

September 27. Wendell Foster, 13, preaches in the R. P. church.

October 1. "Doings" at Wright's.

Остовеr 3. Mr. L. M. Garfield and Miss Rose Livingsion deliver open air speeches on the temperance questicn.

OCtoser 5. New members initiated into the Philadelphian society.

OCTO3ER 9. Wendell D. sher-s the swing on Troul's porch.

Octoeer 10. Wendell and Mildred take their trip to Xenia.

Octoser 11. Rev. J. L. Chesnut of Coulterville, Illinois, preaches in the R. P. church.

October 12. Gavelyte slaff chosen. Surprise on Dr. Chesnut.

OCtOBER 13. The second synod of the U. P. church convenes in Cadarville.

October 14. RAIN! RAIN! RAIN!

OстовеR 15. Dr. McGranahan of Knoxville College, Dr. McMichel of Monmouth, and Mr.

George E. Raitt visit the college and leave some good thots with us.

October 16. Party at Bird's in honor of Mr. Earl McClellan, '13, and Miss Mary Hastings, '14.

OстовеR 17. Rev. C. W. Sullivan delivers a splendid temperance address in the opera house.

October 18. Mr. Earnest Foster, 13, preaches in the R. P. church.

OCtoвer 19. Mr. Ernest Foster present for chapel service.

OстовER 20. "The Oxfords" give an entertainment in the opera house. "Oh bother the flowers that bloom in the spring."

OCtoвer 22. Hutchinson declares his intention to keep on the right side even if it isn't W-R-I-G-H-T.

Octoser 23. The same old story. Rev. Jowelt and Mr. Eavy of Xenia, give us some more

"Home Rule" talk.

October 25. Rev, Earnest McClellan, 09, preaches in the R. P. church.

OctoBer 27. The first frost of the season.

October 29. George Washington of Oberlin, lectures to the colored people.

ОстовеR 30. Hallowe'en party. Particulars elsewhere.

Octóer 31. Big "dry" parade in Xenia.

Novemeer 1. Mr. Andrew Cresswell, 10, preaches in the R. P. church. Dr. Wishart of Xenia, talks "Ohio dry."

November 2. Big "dry" parade in Cedarville. Big crowd to hear Rev. C. W. Sullivan.

November 3. No school. Everybody talks and works for "Ohio dry."

November 4. Bitter disappointment. Home Rule wins. Cedarville dry by 72 voles.

November 6. Mush and milk at the R. P. C. E. poverty social. R. C. H. makes his monthly

visit to Cedarville.

November 10. Rev. Gaily of Philadelphia, leads chapel services.

NOVEMBer 11. Girls' hats disappear.

November 13. Ina Ferris entertains.

November 16. "Merchants' Carnival and Abe Marlin's Wedding."

November 18. Rev. Pallon addresses the Y. M. C, A.

November 19. L. L. Wirt tells of his experiences in Burma and Australia.

November 23. November number of the Gavelyte appears.

NOVEmber 25. Y. M. and Y. W. hold a joint Thanksgiving meeting.

November 26. Everybody thankful-only the chickens and turkeys.

November 27. Recovering from the effects of the day before.

NOVEMBER 30. Everybody returns.

DeCEMBER 1. Thirteen more days till Christmas.

December 3. "The Hoosier Schoolmaster" presented by Noah Beilharz.

December 4. Basket ball-Cedarville 21, Enon 26.

DeCember 6. Townsley club attend the R. P. church (synod) in a body.

December 10. C. E. social at the R. P. church. Apples and bananas in abundance.

December 11. Girls' basket ball-Cedarville 4, Greenville 25. Boys-Cedarville 28, West: Lafayelte 32.

DeCEMBER 15. Oratorical contest. McClure wins.

DECEMBER 16. Rev. Foster delivers an inspiring address to the Y. M. and Y. W. associations.

DeCEMBer 17. The night before getting home. Some leave.

December 18. Everybody leaves. Fond greetings at the end of the journey.

JANUARY 4. Affectionate farewells.

JANUARY 5. Work begins.

JANUARY 5. All busy (?)

JANUARY 7. Annual board chosen and work begins. 


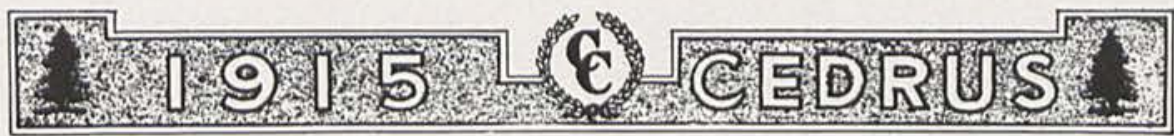

JANUARY 8. Surprise on Mabel Stormont.

JANUARY 9. No one in a hurry to get out of bed.

January 11. Annual contribution of Piso's Almanacs and the American Book Company's Calendar: distributed.

JANUARY 12. Mrs. Gebhardt, state superintendent of the W. C. T. U., in chapel. Class basket ball games. Sum total of poinis-Freshmen 35, Upper Classmen 45.

JANUARY 13. (Miss H. in rheloric): "What do you accept a plan or a proposal?"

JANUARY 15. Hoskinson vociferously expresses his views concerning "Billy" Sunday.

JANUARY 16. "Doc" Lloyd returns to Miller street.

JanUaRY 17. Coach McClure preaches.

JANUARY 18. After much careful thot the Annual is christened.

JANUARY 19. Annual contracts signed.

January 20. Lols of snow to sweep and more "comin'."

January 21. Mr. Roland Nicolls speaks on the subject, "Mind your Business" and also gives a brief account of Harold Bell Wright.

January 22. A C. C. delegation meets Dr. Chesnut at the train and welcomes him to Cedarville,

JANUARY 23. Big fire in the Black Hills.

January 24. Dr. Chesnut preaches his initial sermon in the R. P. church.

JANUARY 25. Picture taking the order of the day.

JANUARY 26. More pictures. Freshman spread.

JaNUARY 27. "Nothin' doin"."

January 28. Reception for Dr. Chesnut. Basket ball-Cedarville 28, Ashland 42.

January 29. Exams. Sled ride to Creswell's.

JANUARY 30. Everybody "sleepin'."

IANUARY 31. Good "skatin"."(?)

Februiry 1. Still at ease.

Ferruary 2. Second semester begins. Rev. Pation speaks. Librarian, Miss Forbes, married.

FEBRU:RY 3. The Totten Company gives an enterlainment, the fifth number of the lecture course.

February 4. The long-heard-of ex-Senator Frank J. Cannon, here at last.

FEBRUARY 5. The basket ball girls are missed.

February 10. "Dave" and Carey teach (?) Bible class.

FEBRUARY 11. Washington and Lincoln memorial day.

Fesruary 12. Day of prayer. Dr. Chesnit preaches. McClure wins sixth place in the Intercollegiate Oratorical Contest.

February 13. Chesnut, Duff, and Company take a walk.

FEBRUARY 15. Some of the would-be farmers and cooks attend the Farmers' Institute.

February 16. Several take advantage of the chicken dinner at the R. P. church.

February 17. McClure expounds the nebular theory at the dinner table.

February 18. The Annual Board makes a flying trip to Xenia.

February 19. Girls basket ball-Jamestown 3, Cedarville 10. Boys-Wilmington 40, Cedarwille 41 .

February 20. R. C. H. visits in the Creswell neighborhood.

February 22. Washington's birthday. No school.

February 23. Old Fiddlers' Contest.

February 26. Rev. H. G. Rice delivers a short address in chapel. Bliss Business College 50 , Cedarville 34.

February 27. Rev. Allen asks Miss Holiday an embarrassing question concerning her age.

MARCH 1. Rev. Allen present for chapel services.

MARCH 2. Miss Ina Ferris enterlains.

MARCH 3. The last day Hazel has any vacant hours; also the last day Paul comes to school.

MARCH 4. Everybody studies (?)

MARCH 5. Girls basket ball-Cedarville 22, Antioch 20. Boys-score forgotten.

MARCH 8. The boys find their room at school nicely furnished.

MARCH 9. The boys get a new rocker as a gift from the ladies.

MARCH 10. Dr. Chesnut speaks in Y. M.

MARCH II. Basket ball-Xenia Federals 32, Cedarville 28 .

MARCH 12. At dinner McClure makes known the astounding truth that every girl, in her own opinion, has the ideal fellow.

MARCH 13. Annual Board busy.

MARCH 15. All busy.

MARCH 17. Dr. Chesnut visits Y. M. Some wear the Shamrock. 


\subsubsection{CEDIULA}

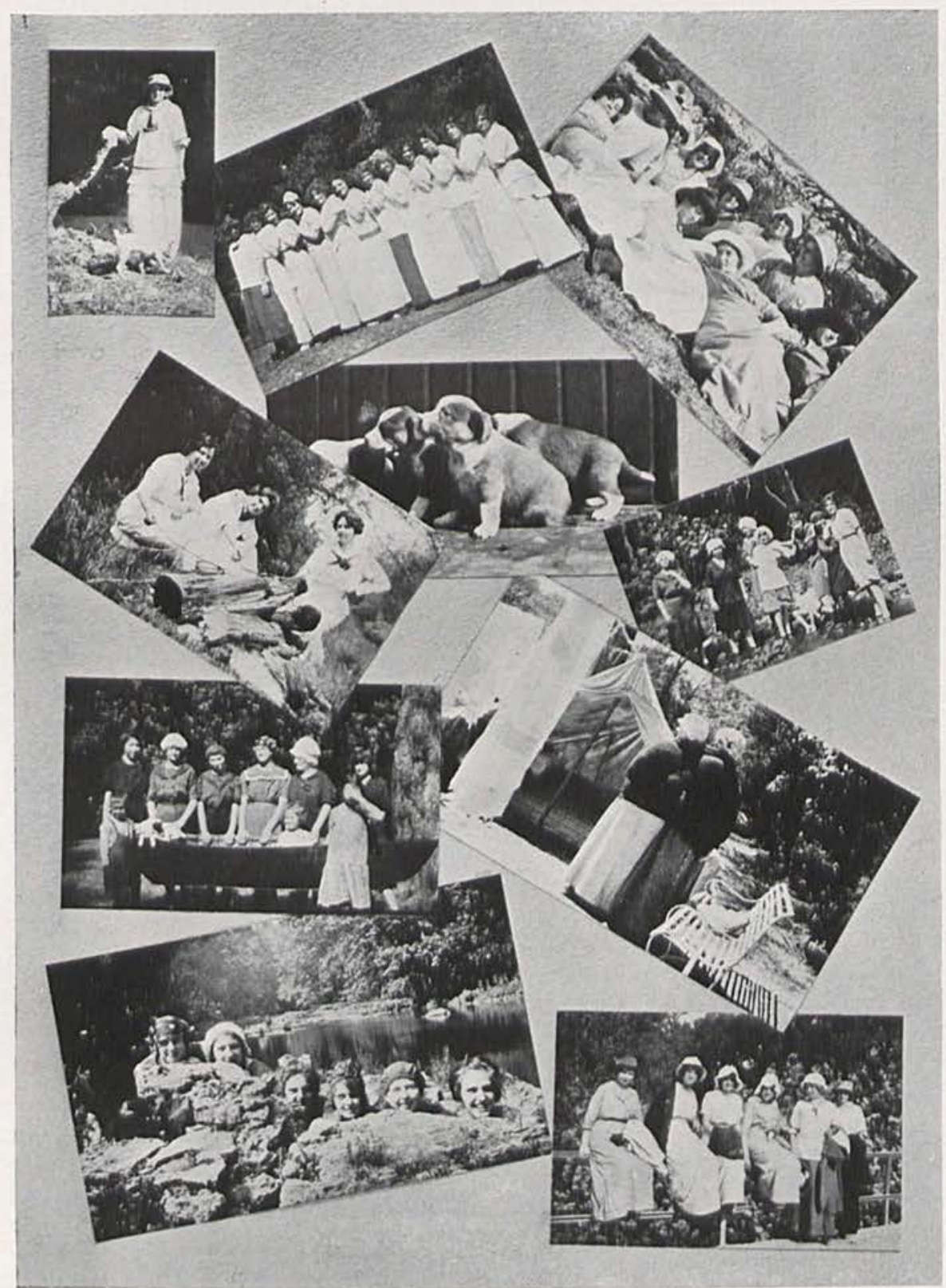

Camp Scenes 

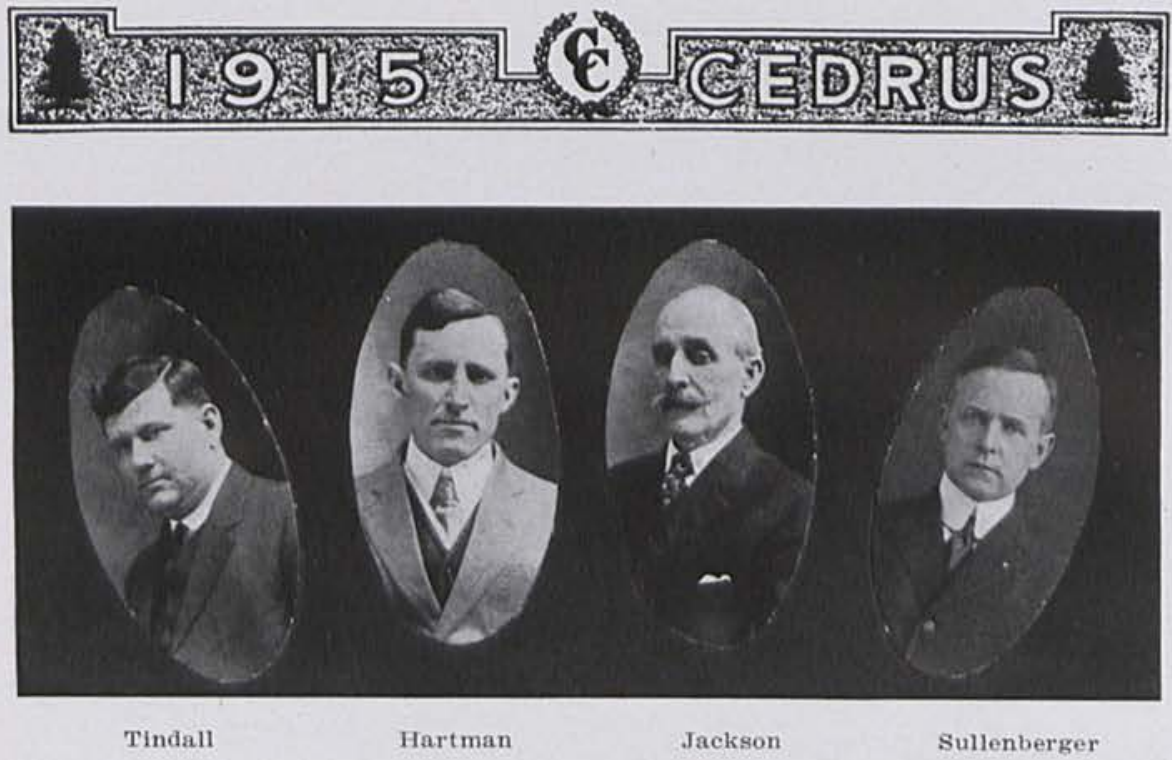

The Board of Trade

HE Board of Trade is an organization of our village representing a number of our business men. The officers are as follows: G. H. Hartman, President; L. F. Sullenberger, Vice President; Andrew Jackson, Secretary, and L. F. Tindall, Treasurer. Dr. M. I. Marsh, Dr. J. O. Stewart, and Robert Bird, together with the officers of the organization, form a Board of Governors.

The purpose of the organization is to promote the best interests of our village, and create and maintain good fellowship among our business men. We believe a great work can be done here by co-operation. We are located in one of the richest counties of the state. Some of the finest stock in the world is raised in this locality. The beautiful scenery in and around our city is second to none. We are also on the Pittsburg, Cincinnati, Chicago, and St. Louis Railroad, one of the best in the United States. We have a splendid little college which is doing a great work, and which we realize is quite an important asset to our town.

Everyone should take a pride in his home town and do all he can to support and strengthen it financially, morally, and spiritually. Remember, we cannot have a progressive town, unless its citizens believe in it, believe in each other, and are willing to work and pull together. Everyone knows the type of a fellow who is always "knocking." We hope that we have none of that class here but if we have they should either quit or move away. The town will be better when they leave, and they will probably be of little use no matter where they go. We may have men walking the streets of Cedarville who are not as much benefit to the town as many who are buried in its cemeteries. Some who have gone have left us a heritage of which we are proud, but the walking dead ones have never done, and never will do, anything either for themselves or others. For this reason, we believe a town is indeed fortunate which can say that all its dead are buried. As some one has said. "Blessed are the dead who die to get out of the way and give somebody else a chance."

Let us then be up and doing and be real "live wires." Let us work and pull together for the advancement of our town. By so doing we will make it a more ideal place for habitation and a place of which we may justly be proud.

Cedarville Board of Trade. 

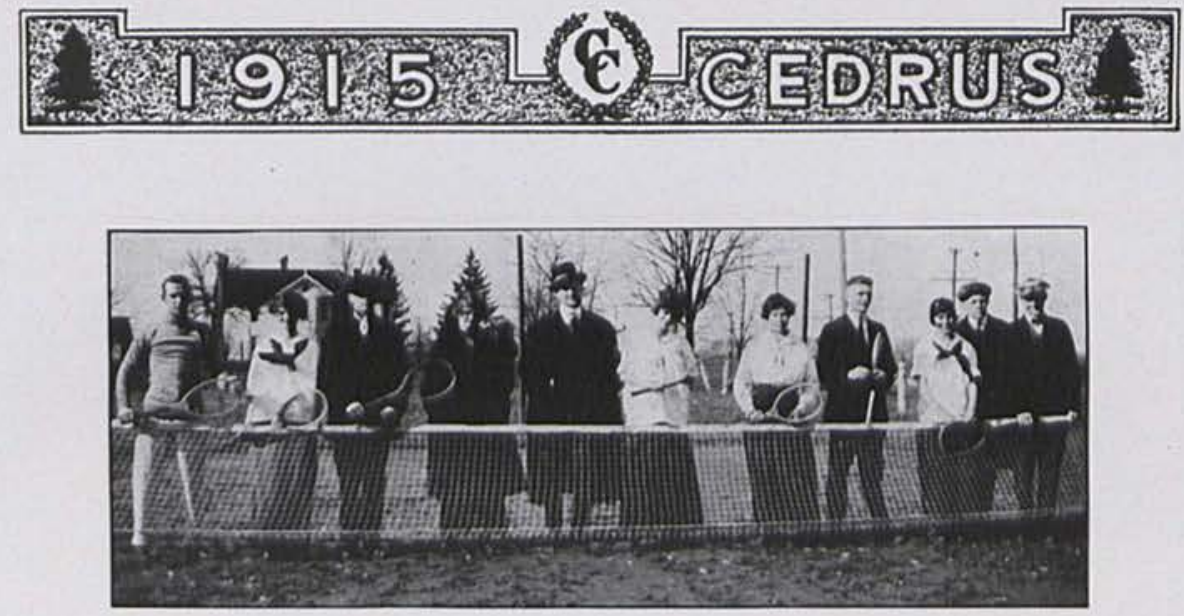

C. C. TENNIS ASSOCIATION

SECOND ANNUAL CEDARVILLE CHAUTAUQUA

Summer of 1915

BIGGER, BETTER, AND GRANDER

Plan to Attend

Executive Committee $\left\{\begin{array}{l}\text { Rev. J. S. E. McMichael, Pres. } \\ \text { G. H. Hartman, Sec. } \\ \text { O. L. Smith, Treas. } \\ \text { L. H. Sullenberger } \\ \text { S. C. Wright }\end{array}\right.$



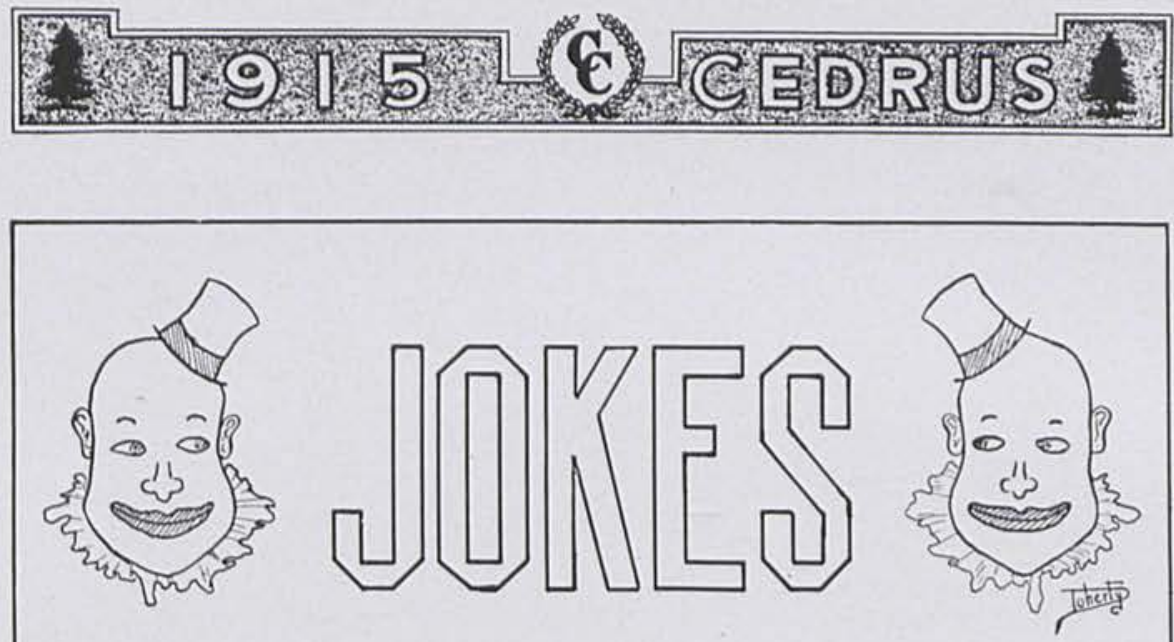

The long looked for lecture on Mormonism came but produced no noticeable effects; Harry merely added another fair one to his list.

Mr. O. M. Ritchie when questioned as to whether he was related to a certain Mr. Harris answered: "Well, not yet, but-" No need for further remarks.

Prof. Allen's interpretation of the passage, "By their fruits ye shall know them.""I think Cedarville College must be a pear tree."

A few excerpts from P. L. R.'s Diary for the year 1915:

Feb. 2- Hazel and I made out our schedules today. Think it the best arrangement possible as we will have so many vacant hours together.

Feb. 3-Spent third hour in chapel.

Feb. 4-Had the best time fourth hour today.

Feb. 5-Got a card from Greenville. My it seemed lonesome in chapel.

Feb. 6-Saturday. I certainly miss being at school today.

Feb. 7-Hazel got home all right.

Feb. 8 - She and I fined five cents each for misconduct in literary. I paid it all.

Feb. 9-Societies have their pictures taken. Hazel played "Princess Royal" while we waited.

Feb. 10-Tempted to cut Y. M. Missed being in chapel.

Mar. 1-We take our places as President and Secretary of the Philosophic Society.

Mar. 2-Decide definitely to quit school. Broke the news gently but thought I saw a tear.

Mar. 3-The last fourth hour together. I know I saw a tear.

Some definitions suggested in English I:

1. "Love is defined by using an illustration from real life- and in comparison with life. Life is one thing after another, love is two things after each other."

Signed,

J. L. C., Jr.

2. "Gingham is a cheap cotton cloth used by women in making aprons and other articles of clothing too numerous to mention."

Signed,

W. W. D. 


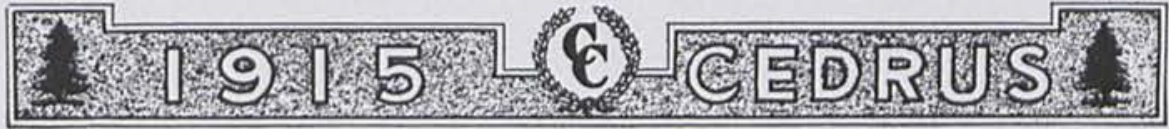

\section{CEDARVILLE COLLEGE}

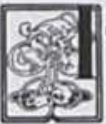

S A VERY good place in which to get your education. It offers courses in the following departments: Collegiate, Normal, Preparatory, Agricultural, Theological, Musical, Oratorical, Art, and Domestic Science. The work is thorough and readily accepted at full value by the largest and best Colleges and Universities, such as Ohio State University, Miami University, Ohio University, Chicago University, University of Michigan, Columbian University, and the University of Pennsylvania. Credit is given for work in the Normal Department toward state certification without examination. The elective system prevails, and with proper restriction, the student is permitted to choose the studies in which he is most interested, for which he is best prepared, and which will best fit him for his chosen life work. Small classes enable both professors and students to do their best work and get the most out of it. The moral and religious influences are of the best. A free employment bureau is maintained and is successful in placing graduates in places of usefulness. Last year every member of the graduating class who wished a position was definitely employed within a week after commencement. Tuition in the Preparatory and Theological Departments is absolutely free and in all other Departments the rates are very low. Living expenses are extremely low. Many who could not afford the expense of a College education elsewhere are able to obtain one at Cedarville. A catalogue and further information can be obtained by writing to Cedarville College, Cedarville, Ohio. 


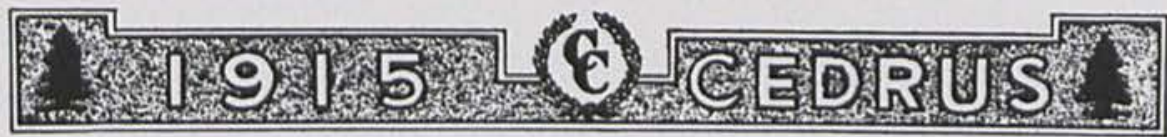

\section{Afterword}

N THE foreword at the beginning of the book, it was stated that the sense of the shortcomings of the book weighed heavily on the shoulders of the publishers. The load has not lightened one iota since leaving that port. The ship has nearly run aground more than once, and several times the hands have fallen asleep on the job. However, after a long, hard voyage she has finally reached her destination. The helmsman has ceased to use the levers by means of which he controlled her course, and now the cargo is ready to be delivered into the hands of the printers and later to the students and friends of our beloved Alma Mater.

Now, to drop our figure, the first volume of the Cedrus is being presented to the students and friends of the College and we hope it will be favorably received. We have endeavored to present college life as it actually is at Cedarville College. We wish again to thank all who have helped us in the publication of the book. If in perusing the pages previous to this, you have found any particularly good things, credit them to those who have helped us. As for the faults-well, the camel's back isn't broken yet.

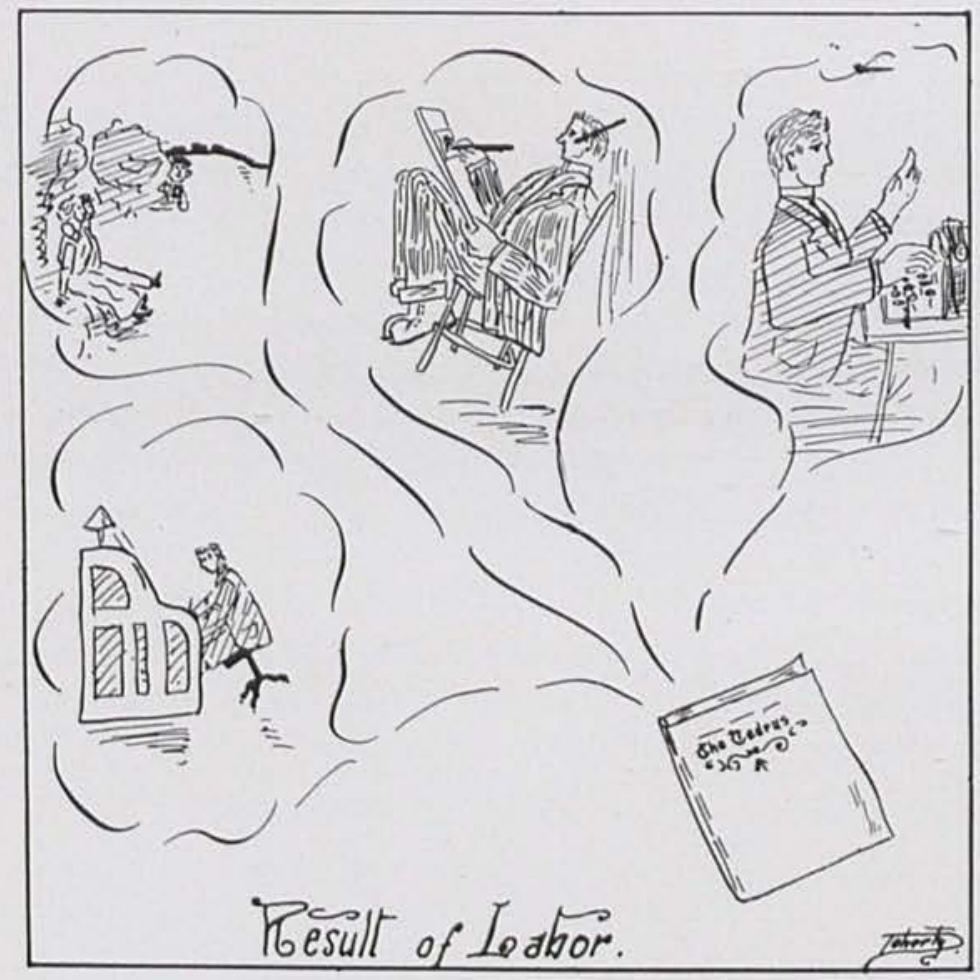




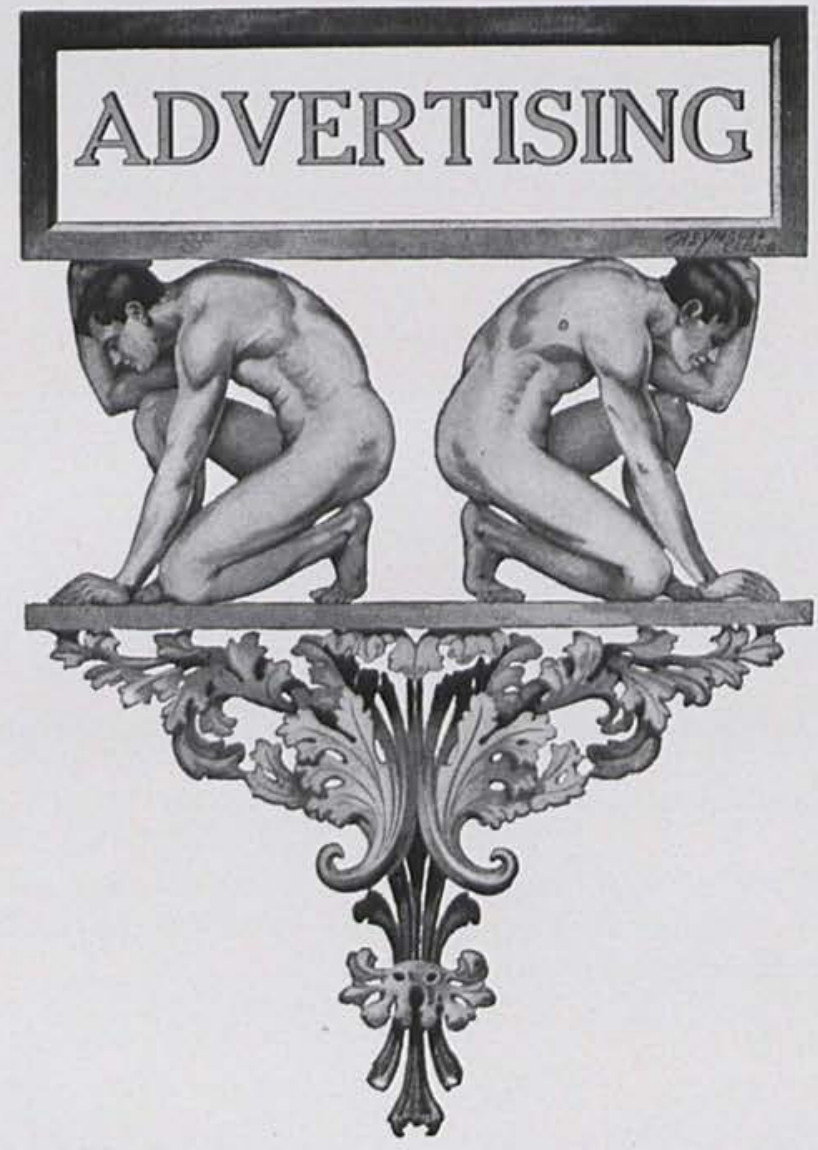

Don't fail to look through the advertising sections. There is something there you will want to see. Something worth while. 


\section{Richards Drug Store}

THE STUDENTS' STORE

The Finest Soda Fountain in Town ATHLETIC GOODS
The Freshest Chocolates

SUNDRIES COMPLETE

\section{RICHARDS DRUG STORE}

Phone 203

Cedarville, Ohio

Student- "Were you on your knees when she proposed?"

Prof. A.- "No, but she was."

Miss H.- "Where do dates come from?"

Dorothy - "Oh, most anywhere."

Prof. A. (in Bible) - "Can any one tell me how many wives Solomon had?"

Miss T.- "Seven hundred wives and three hundred concubines."

Miss Z.- "How old was he?"

Prof. A.- "About sixty."

Miss Z.- "Gee, he must have went some to get so many wives in so short a life."

\section{GROW WITH US}

We want your account-want to make ourselves useful to you in anything pertaining to finance-and we can handle it with profit to you and to ourselves.

Paid Capital $\$ 40,000$. Surplus $\$ 2,500$. 4 per Cent Interest Paid on Savings.

Cedarville, Ohio THE EXCHANGE BANK

\section{The Palace of Sweets}

FRESH BREAD, CAKES, PIES

Special attention given to Orders for Parties, Spreads, Church

$$
\text { Socials, Etc. }
$$

EVERYTHING THE BEST

J. E. Post

PHONE 44
McDORMANS

Quality Store

SELLERS of SMART CLOTHES

Without City Prices

Agents of Stetson Hats

JAMESTOWN, OHIO 


\section{TO THE MAN WHO CARES}

FOR

Good Clothes, Stylish Clothes, and Serviceable Clothes at Reasonable Prices.

Go To

Home Clothing Co. Cedarville, Ohio NOTICEI WE KEEP OUR SUITS PRESSED ONE YEAR FREE

The Great Annual

Dividend Company

LOWEST

NET COST RECORD

THE WIDE WORLD OVER

\section{THE UNION CENTRAL}

LIFE INSURANCE CO.

C I N C I N N A T I, O H I O.

JESSE R. CLARK, President

\section{JOSEPH A. BORAFF, District Agent, XENIA, OHIO}

Prof. A. (to a dog attempting to enter the class-room) - "Dog, you get out; we have enough in here."

Hutchinson (in a debate) - "Why couldn't we consecrate our troops along the Canadian border?"

Prof. A. (in a recitation from "The Independent") - "Mr. Bradfute, will you take 'Utopia or Hell?'”

Wilmah- "The ablative of instrument is used with misceo and mutare to mix honey with wine."

THE ONLY DIFFERENCE BETWEEN OUR THEATRE AND OTHERS IS THE QUALITY

XENIA THE BIJOU THEATRE OHIO 


\section{Thorb Charters JEWELER}

Now Located at

443 E. Main Street XENIA, OHIO

\section{Galloway and Cherry}

11 E. MAIN ST. Xenia, Ohio

Headquarters for Reliable

Carpets, Rugs, Linoleums,

Draperies, Etc.

\section{OHIO PRIDE FLOUR}

For particular people who can use only THE BEST EVERY SACK GUARANTEED

MANUFACTURED BY

George, \& Ervin Bros.

Jamestown, Ohio

Kerr \& Hastings Bros. Cedarville, O. Distributors

\section{What Would Happen If}

Carey's Bird should fly?

"Dave" should bite his tongue?

McClure should comb his hair?

Wilmah should lose her $w(W)$ ard?

The Freshmen should have a spread?

Rife should be on time?
Duff should fail to get a hundred?

Prof. Allen should lose his watch chain?

Ruth R. should say she had her lesson?

Doherty should quit his flirting?

Warren should go up in smoke?

Irene should roast her Chestnut?

Paul should lose his Gardiner? Milred M. should fail to get another fellow? Dr. McKinney should forget his usual announcement?

\section{YES}

We always have a fine line of fresh and smoked meats, choice fruits of all kinds.

OYSTERS IN SEASON

Cultice Meat Market

CEDARVILLE, OHIO

\section{WATCH}

Your Step and Take Your Watch, Clock, Jewelry and Optical Work to

S. J. WHITT

6 S. Detroit St. Xenia, O. 


\section{SEE \\ The Tarbox Lumber Comany}

FOR ALL KINDS OF BUILDING MATERIAL

Bring in Your Bills and let me make an Estimate on the Cost of that New Improvement. Reliable Goods at a Reasonable Price

Cedarville Phone 33 Ohio

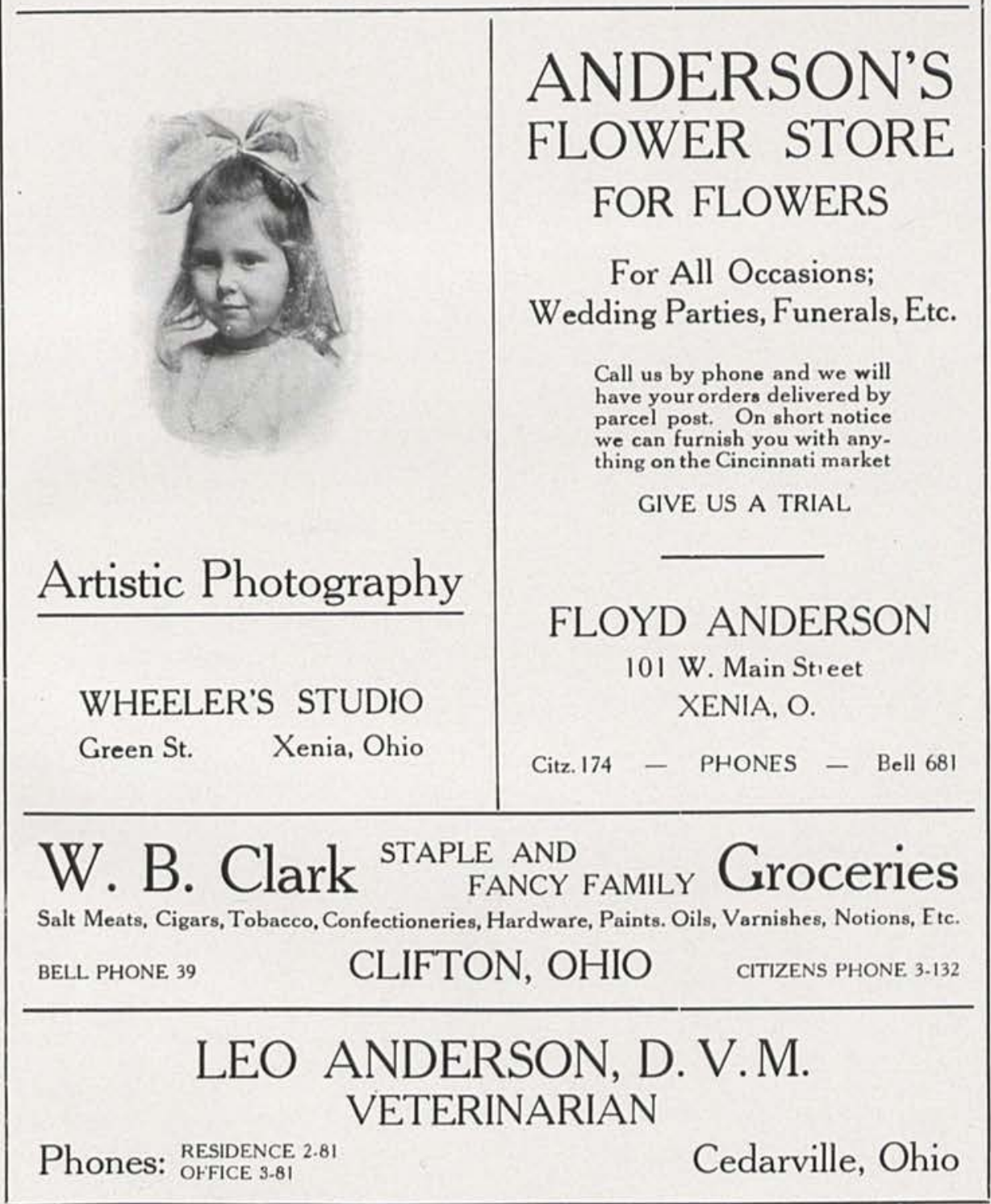




\section{IF YOU DESIRE}

Real Art in Design, Finest Quality of Material, Highest Class Workmanship IN EXECUTION OF MAUSOLEUM MONUMENT MARKER or other memorial, you can find a concern that will not disappoint you in

THE GEORGE DODDS \& SONS GRANITE CO.

KEENE, N. H.

$$
\text { XENIA, OHIO }
$$

MILFORD, MASS.

Quarrymen, Manufacturers, Designers and Builders

FINEST AND BEST EQUIPPED PLANT IN THE UNITED STATES

With an unbroken record of fifty years square dealing. Work shipped direct from quarries. Write us for designs and estimates

\section{CEDARVILLE THEOLOGICAL SEMINARY}

CEDARVILLE, - OHIO

1. Theological, three years.

Courses 2. Combination Collegiate and Theological, four years, leading to the degree of A. B.

of 3. Bible Training and Missionary, two years.

Study 4. Post-graduate Work for the degrees of B. D. and A. M., one year.

Courses 2 and 3 are open to both sexes.

Good Library with leading periodicals.

Next year begins September 14, 1915.

Advantages free to all denominations.

SEND FOR CATALOGUE TO

W. R. McCHESNEY, Dean

W. D. PRINTZ Compliments of....

Dealer in

Groceries, Notions, Boots, and Shoes

ICE CREAM A SPECIALTY

Orders Filled Promptly

Bell Phone 36

Clifton, Ohio

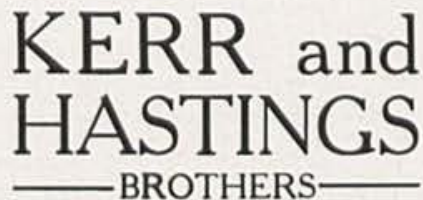

Cedarville, 


\section{MAKING SURE}

Many years of successful business has taught us that there is one way to make sure of the continued patronage of our customers. That is to sell them only the best goods at sight prices. That is the reason for our selling Society Brand Clothes, Hart, Schaffner and Marx and Clothcraft all wool clothing.

\section{A. WEAVER}

Main Street

\section{Opposite Court House}

Xenia, Ohio

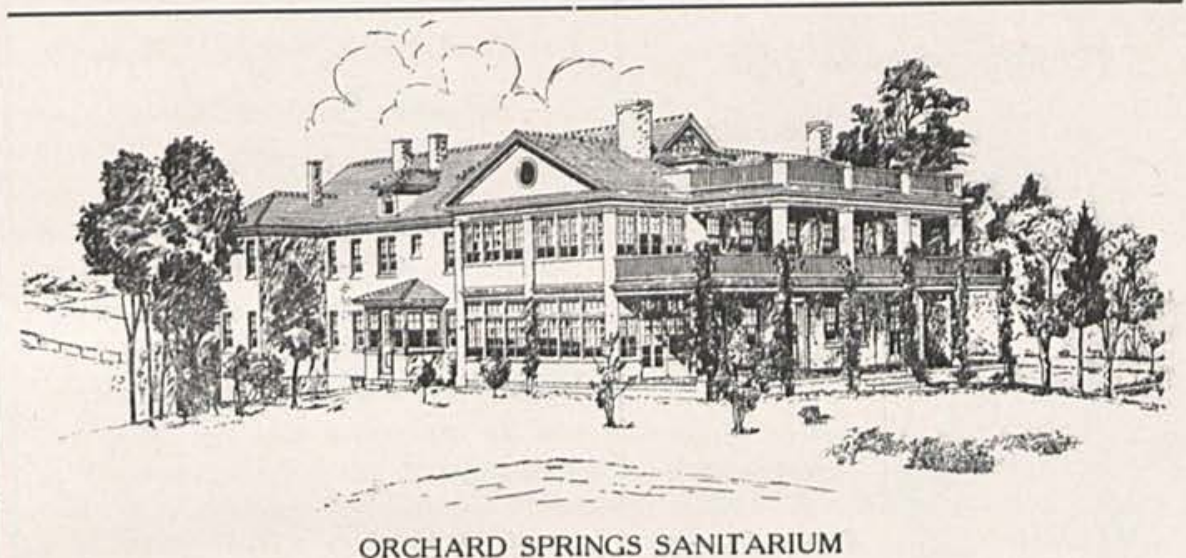

A private Hospital for the care and treatment of Nervous and Mental Diseases, Alcohol and Drug Addictions and selected cases of general Invalidism.

Location is ideal. The Sanitarium overlooks Stillwater Valley, a region noted for its srenery and healthful environment. The building is commodious, rooms are large, airy and well lighted.

Trained nurses and individual medical attention, using the most approved methods, constitute the keynute to our treatment. Outdoor amusements are furnished and encouraged and everything is planned for the comfort of the patient. For full information address

\section{DR. J. C. GEORGE, Resident Medical Director ORCHARD SPRINGS SANITARIUM DAYTON, OHIO}

\section{THE WESTERN THEOLOGICAL SEMINARY PITTSBURG, PA.}

A faculty of ten Professors offer a complete modern theological curriculum, with elective courses leading to the degree of B. D. Graduate courses of the University of elective courses leading to the degree of $\mathrm{B}$. D. $\mathrm{Ph}$. D., are open to properly qualified students of the Seminary. Exceptional library facilities, Seminary library of thirtystudents of $\$ 150$ each and two post-graduate fellowship, of $\$ 500$ each. We have a new dormitory equipped with latest modern improvements. There is a social hall, students common, and gymnasium with an instructor. The next term opens September 21, 1915.

For Information Apply to

President, JAMES A. KELSO, Ph. D., D. D. 


\section{THE NAGLEY STUDIO

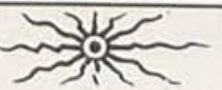

\section{Artistic Photographs Our Specialty}

Kodaks, Supplies, and Post Cards. Picture Framing

\section{CEDARVILLE, OHIO}

\section{Ready-to-Wear}

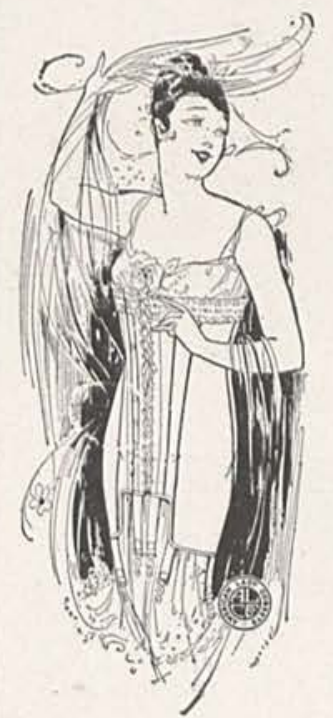

\section{Hutchison \& Gibney Xenia, Ohio}

June 21.

August 13.

Wooster Summer School

\section{Wooster, Ohio}

Invites every reader of the Cedrus to send for its catalogue, and then to arrange to spend the summer in study under its direction. All will be made welcome. Recent legislation for professional training and life certification fully met in every particular.

\section{J. H. DICKASON, Principal}

Carpet Department has a fine supply of all the newest designs. Silks, Hosiery, Laces, Waists,

Suits, Skirts,

Underwear.

\section{Central Hotel}

Restaurant in Connection

Short Orders a Specialty

Millard F. Sullivan Cedarville, Ohio

McClure (to the loafers in the restaurant) - "Say- did-you-fellows-everread - that-speech-of-Shyrock-to-Onteneo?"

If the Cedy (Cedrus) ran things at Cedarville: annually.

I. He would see that "Cedar Day" came semi-annually and Dr. McKinney

2. He would combine the boys' and girls' waiting rooms and put rugs and rocking chairs in all the class rooms.

3. He would run an elevator from the basement to the third floor.

4. He would see that Prof. Jurkat didn't wear rubber heels.

5. He would raise the salaries of the "Profs" and shorten their hours of labor. 


\section{THE C. R. PARISH CO.}

Stoves, Household Goods of All Kinds

285 DETROIT ST

XENIA, OHIO

Do You Care for Bargains? SEE ME FIRST

Some article at a bargain every day VEGETABLES

Fish and Oysters in Season

C. M. SPENCER

The Sanitary Grocery

Phone 3-110

CEDARVILLE, OHIO

\section{Babb Means Best}

Hardware

Buggies

Implements

Harness

Engines

Paints

-C. L. BABB-

16 S. Detroit St. Xenia, Ohio

KNOTtY Things tied.

At society - a motion for adjournment had bee made and the "ayes" and "noes"

Merle (laying his hand on Helen's arm) - "That's right, we want to always stay tied, don't we?"

Note appended to an Education test paper belonging to "Cam" Ross-" "There's not much of Bolton's Principles of Education in this. It's mostly imagination."

Answer from Prof. Allen - "Not much thought either. It has to be based on knowledge."

Irma- "In the refrigerator system in New York they store chicken and poultry and other vegetables."

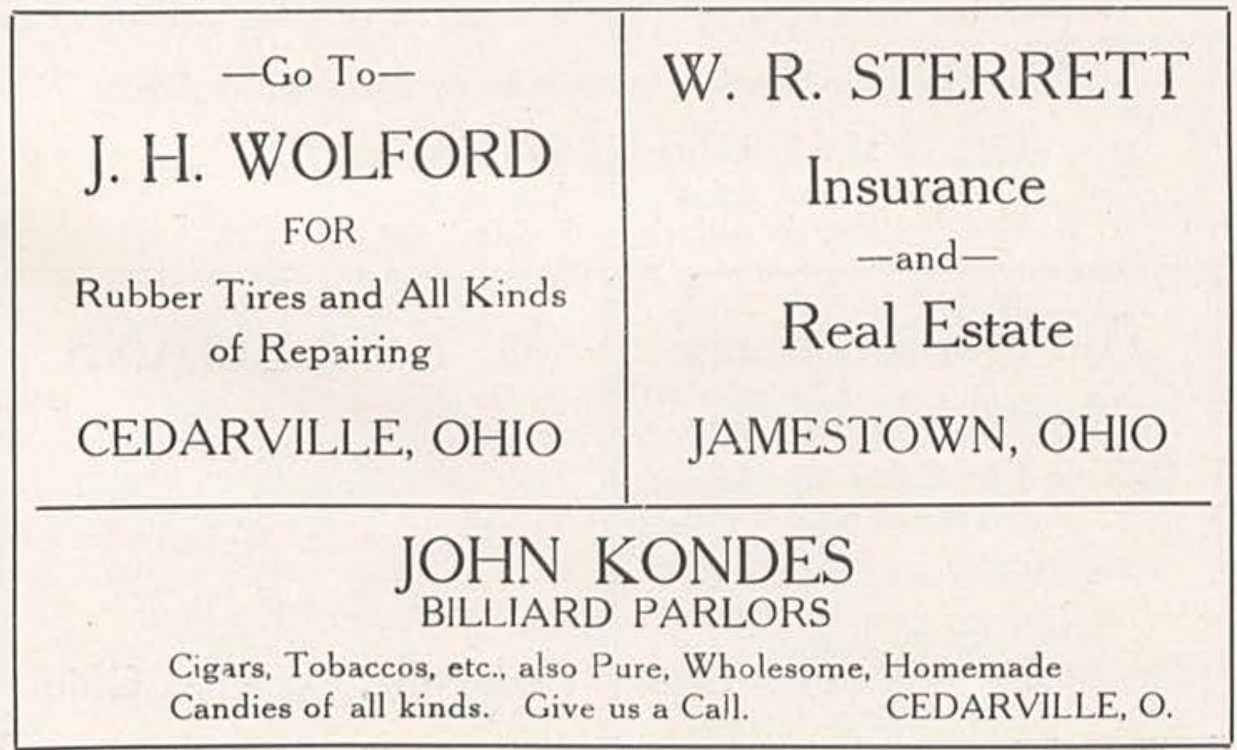




\section{WATTS QUALITY ICE CREAM}

Will be served in Cedarville by

\section{RICHARD'S DRUG STORE}

We are making the cream over a special formula used only by $\mathrm{Mr}$. Richards and W. H. Donges of Xenia. We recommend Richards

Drug Store for Purity, Cleanliness, Courtesy.

Our Store is Headquarters for Students Wants

Pennants, Sweaters, Hats

Tennis and Basket Ball

Shoes. :-: :-: :-:

Fancy Box Candy $25 \mathrm{c}$ to $\$ 1.00$

ROBT. BIRD

Cedarville,

\section{ZELL'S BOOK STORE}

Stationery and Office Supplies

Picture Framing

BOTH PHONES

6. S. Detroit St., Xenia, O.

Prof. Allen-."There is an awful waste of the English language on the part of some teachers."

Warren Barber (in Literature) - "The selection for study today is Wordsworth's 'Ode to Immorality.",

"Who was Pluto?"

"Why, he was Plato's twin brother."

Two important arguments against women suffrage as given by a member of the debating class: not get it."

I. "Very likely Jack Sprat's only reason for not liking fat, was that he could

2. "Women are hard to live with but they are harder to live without."

Prof. A. - "What is your authority for these statements?"

W. A. H.- "I looked for authority and couldn't find it."

\section{The Home Bakery}

Bakes fresh bread every day.

Delicious Pies, Cakes and Pastries a Specialty

DELIVERY EVERY DAY

JACOB SEIGLER

Phone 65.
Cedarville, Ohio

\section{W. L. CLEMANS}

Real Estate, Loans

$$
\text { - and- }
$$

Insurance Agency

ESTABLISHED 1896

Cedarville, - - Ohio 


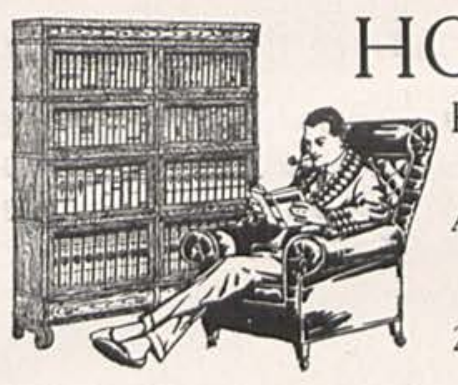

FOR HOMES OF CULTURE AND REFINEMENT

At Prices Usually Asked for Very Ordinary Kind

\section{ADAIRS}

20-24 N. Detroit St. FURNITURE, CARPETS, STOVES

Xenia, Ohio

A Home Paper That Is Highly Regarded by Advertisers

\section{The Cedarville Herald CEDARVILLE, OHIO}

For thirty-eight years it has been recognized for its stability and influence. Always aggressive and newsy

The Herald reaches the best class of people, the progressive and well-to-do farmers, in the best township in the state

Funeral Directors

Ambulance Service

NAGLEY BROS.

Cedarville, Ohio

PHONE: Store 40; Residence 84
BASTIAN BROS. CO. Manufacturers of

Class Emblems, Rings, Fobs, Athletic Medals, Wedding and Commencement Invitations and Announcements," Dance Orders, Programs, Menus, Visiting Cards, etc.

Samples and Estimates furnished upon request 720 BASTIAN BLDG., ROCHESTER, N.Y. 


\begin{tabular}{|c|c|}
\hline GEO. H. SMITH M. W. COLLINS & L.S. Bar \\
\hline Smith \& Collins & WALL PAPER, PAINTS, PICTURE \\
\hline $\begin{array}{l}\text { REAL ESTATE } \\
\text { We endeavor to please both buycr and seller. } \\
\text { We do a strictly } 2 \% \text { commission business. }\end{array}$ & $\begin{array}{c}\text { FRAMING, MCCALL PATTERNS, } \\
\text { STATIONERY, POST CARDS, } \\
\text { BOOKLETS, NOVELTIES }\end{array}$ \\
\hline $\begin{array}{c}\text { CEDARVILLE, OHIO } \\
\text { OFFICE, s. MAIN ST. }\end{array}$ & Green St. \\
\hline
\end{tabular}

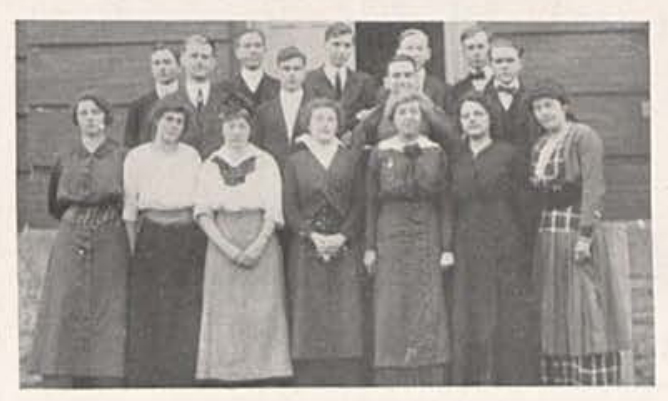

The Bible Reading Contest was held April 16. The prizes were awarded to Miss Florence Somers, Miss Dorothy Collins, and Mr. McClure. It was the best one yet held, and Dr. Ritchie has offered to give prizes for a like contest again next ye:r.

BE FRIENDLY

CALL OFTEN

Margaret McNeill

Fannie McNeill

A Full Line of

\section{General Merchandise}

ROBERT ELDER SELMA, OHIO

Prices Right

Courteous Treatment

\section{DRESSMAKING}

Phone 168

The Misses McNeill CEDARVILLE, OHIO

\section{The Smith Advertising Co.}

PUBLISHERS AND COMMERCIAL PRINTERS

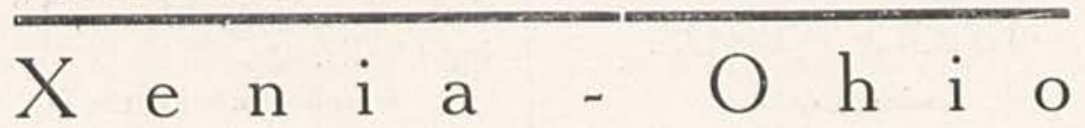




\section{PROMINENT LIVE STOCK BREE.DERS}

\section{MEADOW BROOK \\ Herd of Aberdeen-Angus Cattle \\ O. E. BRADFUTE, Route 5, XENIA, OHIO \\ Stock of All Ages for Sale}

Greene County is the most noted county for registered live stock in America, and Meadow Brook is one of the most noted stock farms in Greene County. VISITORS ALWAYS WELCOME EXCEPT ON SABBATH

First Student- "What does Anna Collins' hunting a fellow put you in mind of?" town."

Second Student-" That's easy! Harry Bird, when there's a new girl comes to

Mr. Doherty about Christmas time in writing a letter home- "I'm tired of walking around with me hands in me pockets and nothing in me pockets but me hands-."

Dialogue at Townsley's Evolution theory affirmed and denied:

Mr. Duff-"What convinced me of evolution was the nebular theory."

Mr. McClure (after an interval filled with bites of bread, potatoes, beans, and corn) - "Well, that man Nebular was no doubt an atheist, as all the other scientists are."

William H. Creswell

Howard C. Creswell

\section{OAKWOOD FARM}

Registered Polled Durham Cattle

Registered Large Type Poland China Hogs STOCK FOR SALE

CEDARVILLE

$\mathrm{O} \mathrm{H} \mathrm{IO}$

XENIA, R. F. D. NO. 2

BELL, PHONE 700-11

\section{W. D. CHERRY}

BREEDER OF

Hampshire Down Sheep and Short Horn Cattle

ALL STOCK REGISTERED

XENIA, OHIO 


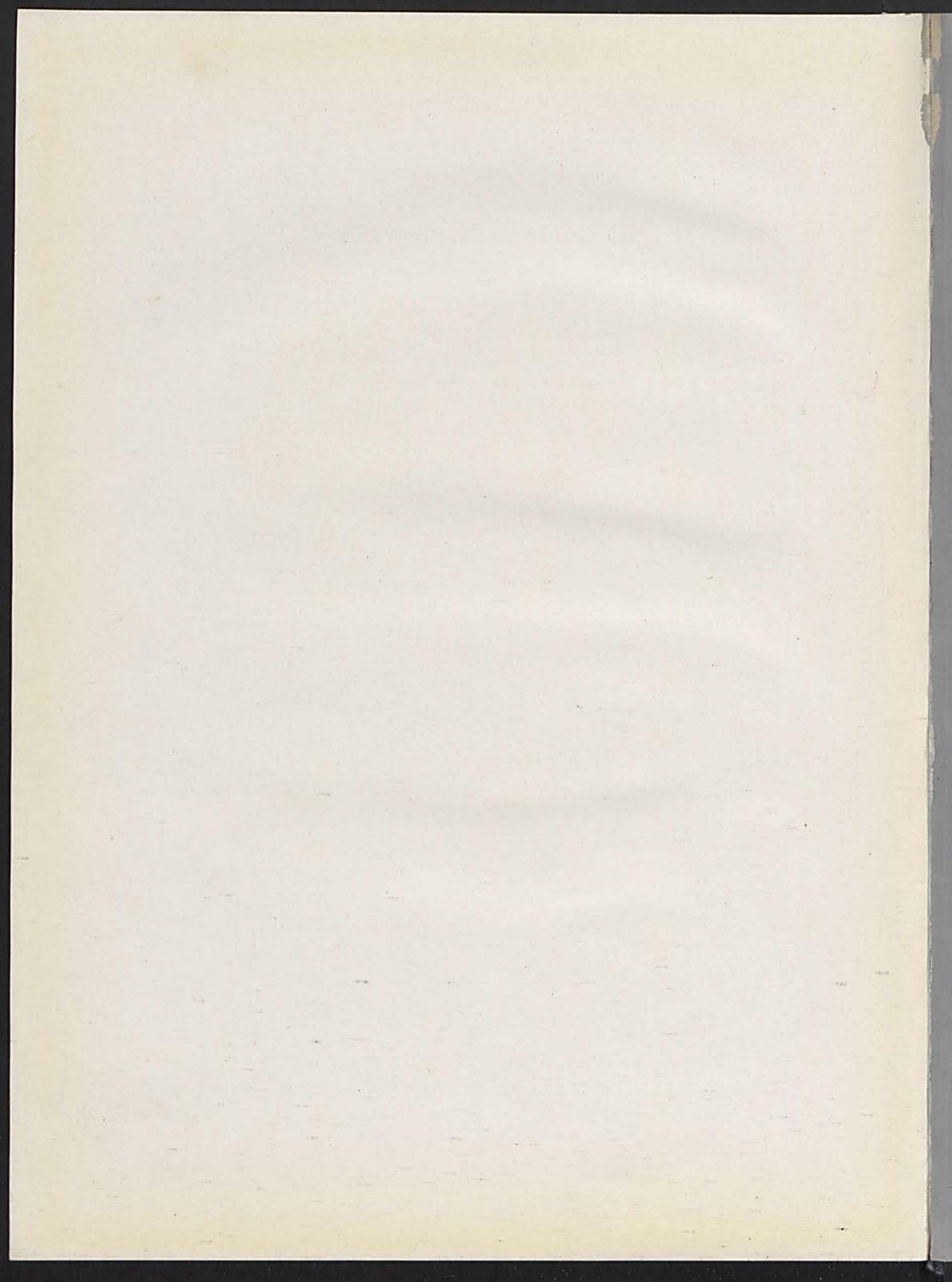




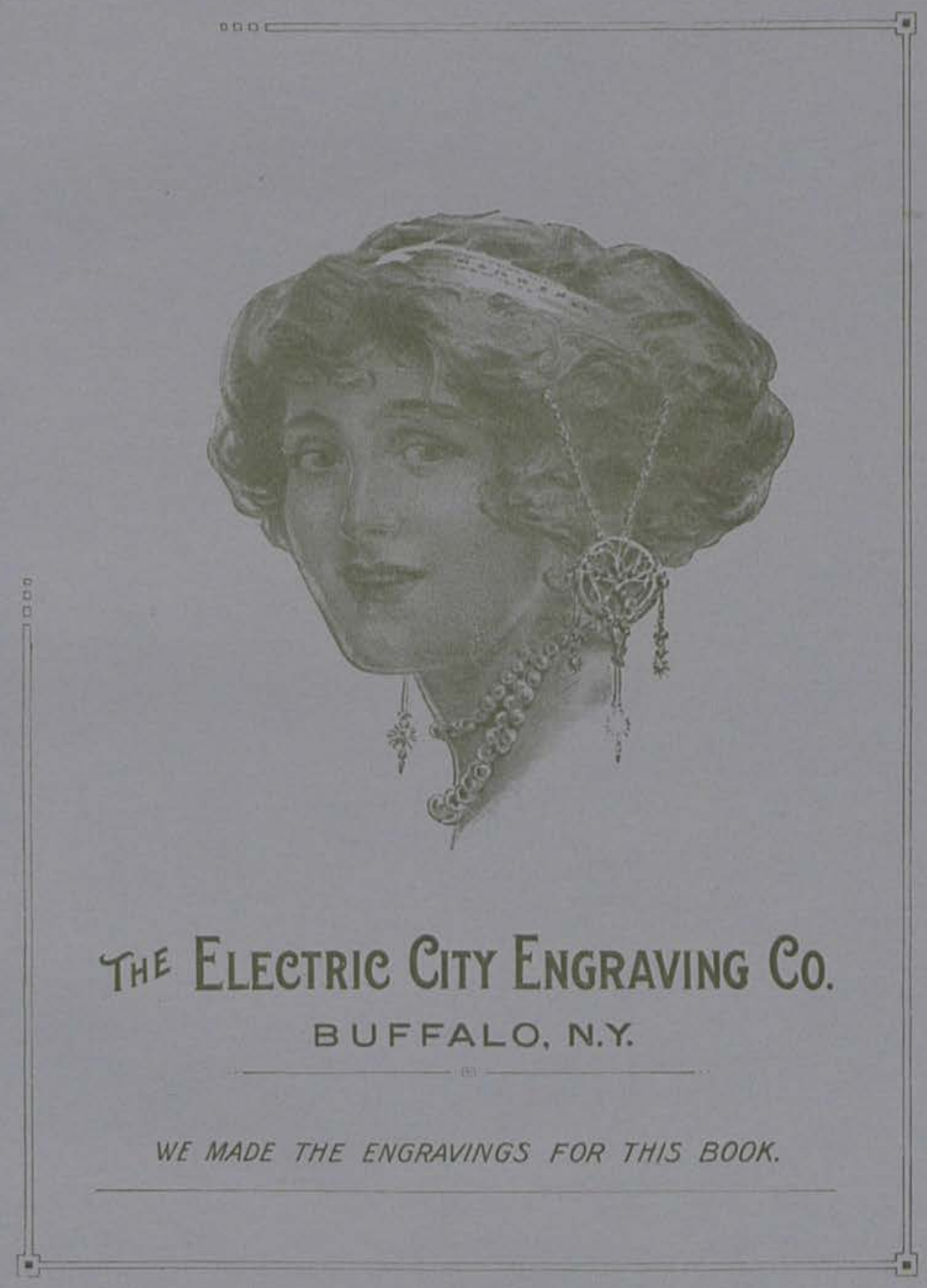




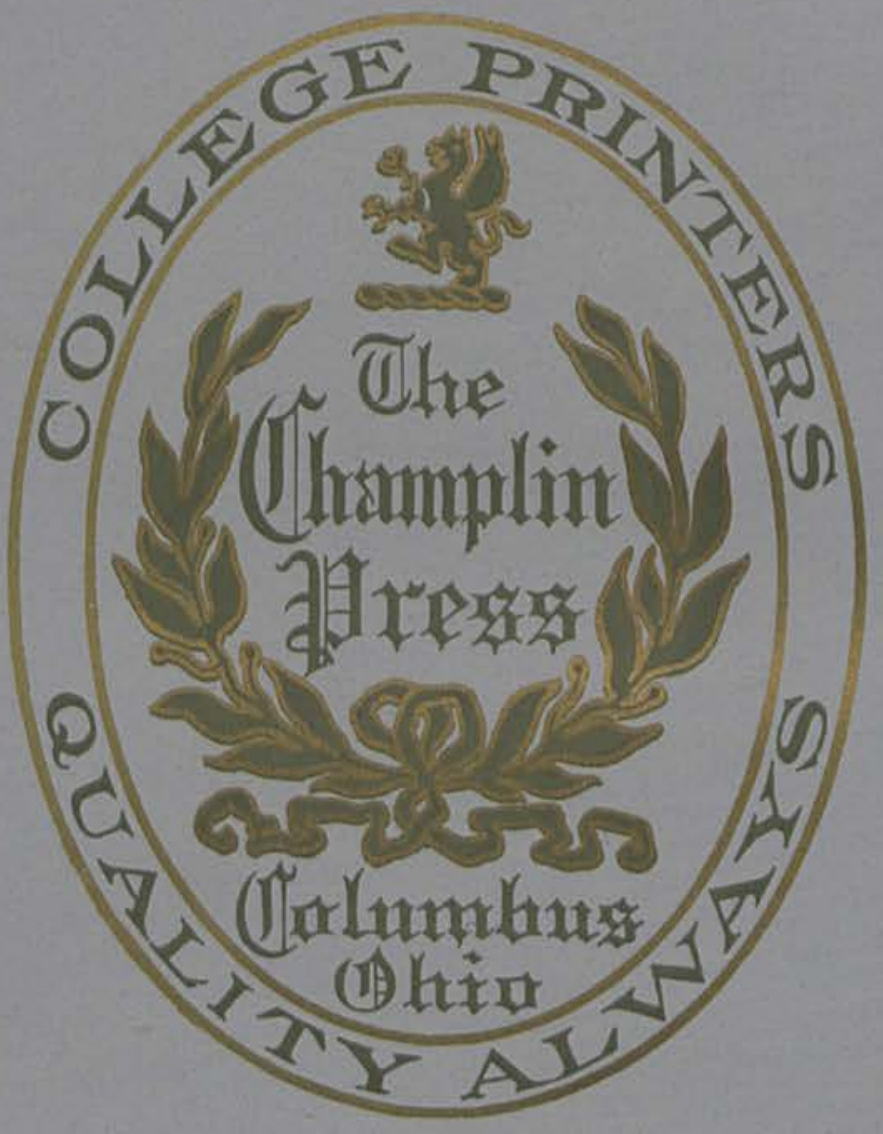

The Champlin Press, maken of thir book, grint . YORE Collese Catakogs. Annuak, Vievs Bulletins and Calendares than any Ether 1893 . Nome $\$ 90,000$. Eathlithed 1893. Assets $\$ 90,000$

THIS INSERT IS PRINTED ON THE CENTRAL. OHIO PAPER CO'S. $32 \times 44-120$ GREFN EUCLID SEMI-DUH L. ENAMEI. 


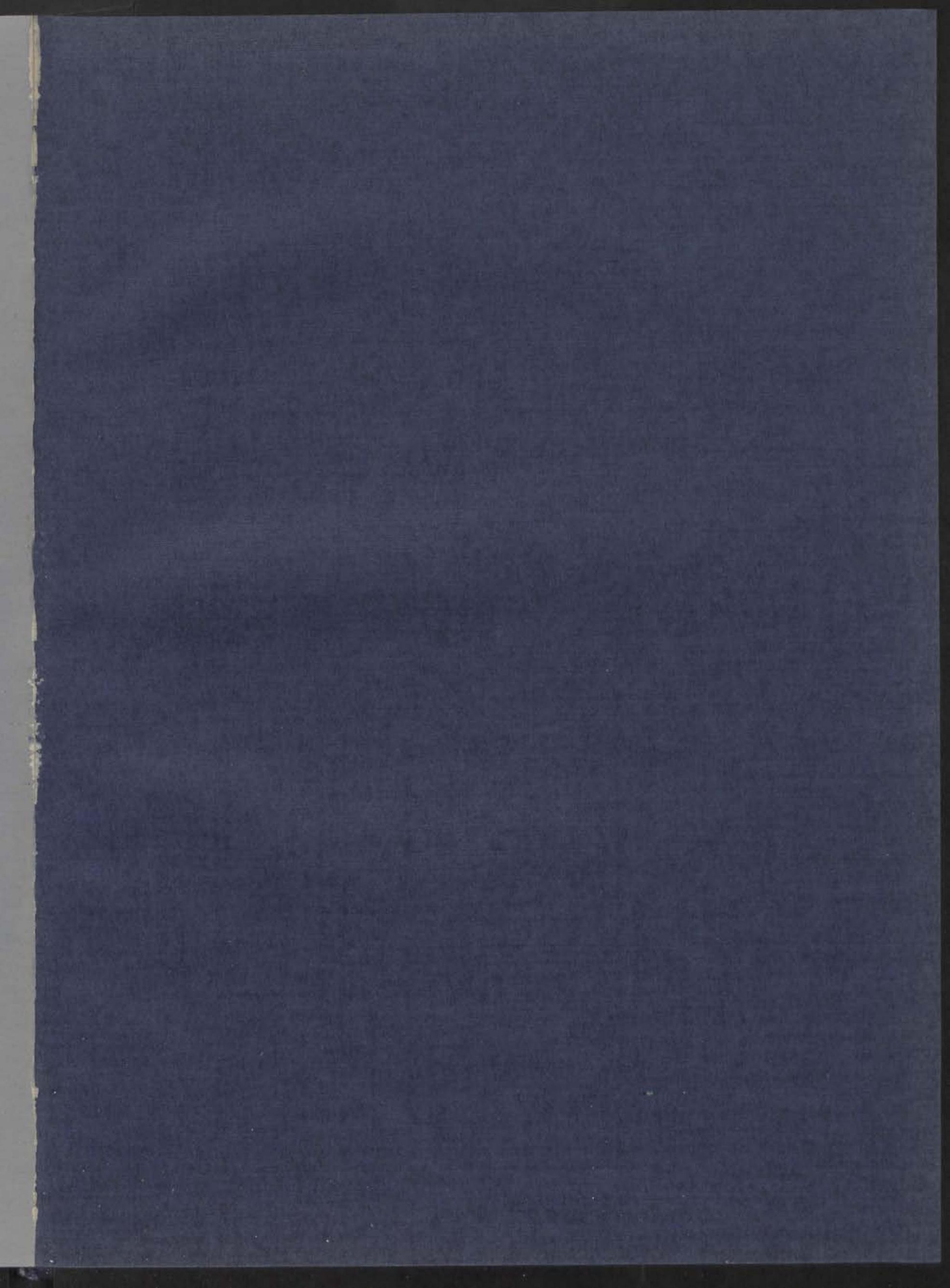


For Reference

Not to be taken

from this library 
